\title{
Ethnohistoric Notes on Indian Groups Associated With Three Spanish Missions at Guerrero, Coahuila
}

T. N. Campbell

Center for Archaeological Research

Follow this and additional works at: https://scholarworks.sfasu.edu/ita

Part of the American Material Culture Commons, Archaeological Anthropology Commons, Environmental Studies Commons, Other American Studies Commons, Other Arts and Humanities Commons, Other History of Art, Architecture, and Archaeology Commons, and the United States History Commons

Tell us how this article helped you.

This Article is brought to you for free and open access by the Center for Regional Heritage Research at SFA ScholarWorks. It has been accepted for inclusion in Index of Texas Archaeology: Open Access Gray Literature from the Lone Star State by an authorized editor of SFA ScholarWorks. For more information, please contact cdsscholarworks@sfasu.edu. 
Ethnohistoric Notes on Indian Groups Associated With Three Spanish Missions at Guerrero, Coahuila

\section{Creative Commons License}

\section{(c) (1) \&}

This work is licensed under a Creative Commons Attribution-NonCommercial 4.0 International License 


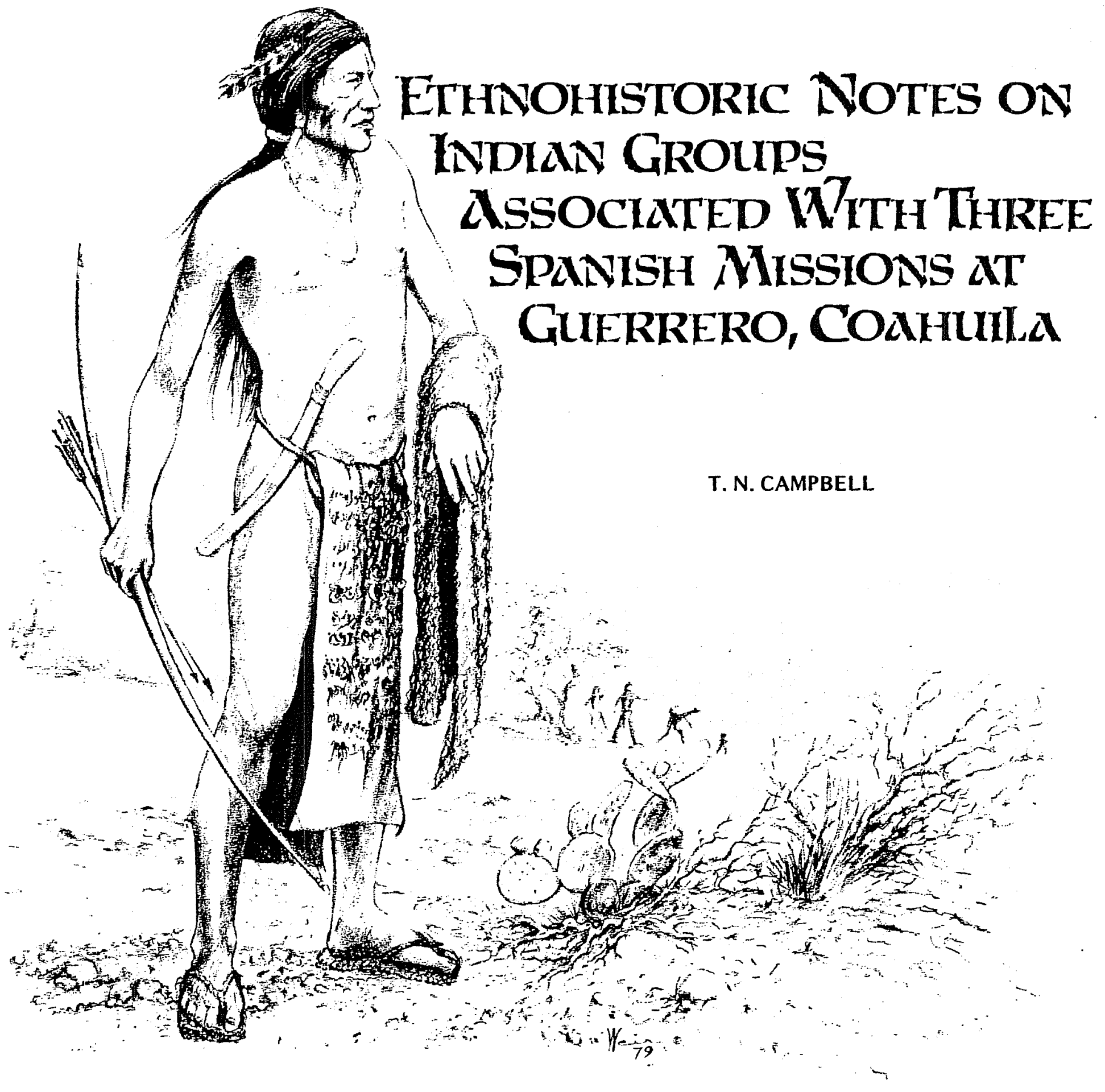

Center for Archaeological Research

The University of Texas at San Antonio

Archaeology and History of the San J uan Bautista Mission Area,

Coahuila and Texas, Report No. 3 
Center for Archaeological Research

The University of Texas at San Antonio

78285

Thomas R. Hester, Director

Archaeology and History of the San Juan

Bautista Mission Area, Coahuila and Texas

This series of publications presents information gathered from archaeological investigations and historical research at the Spanish mission complex in the area of Guerrero, Coahui 1a, Mexico. Additional volumes are forthcoming.

No. 1 (1979) Crossroad of Empire: The Church and State on the Rio Grande Frontier of Coahuila and Texas, 1700-1821. By Felix D. Almaraz, Jr. 77 pages. $\$ 5.00+.28$ tax for Texas residents.

No. 2 (1979) Inventory of the Rio Grande Missions: 1772; San Juan Bautista and San Bernardo. Translated and edited by Felix D. Almaraz, Jr. In press.

No. 3 (1979) Ethnohistoric Notes on Indian Groups Associated with Three Spanish Missions at Guerrero, Coahuila. By T. N. Campbel1. $\$ 4.00+.22$ tax for Texas residents. 
ETHNOHISTORIC NOTES ON INDIAN GROUPS ASSOCIATED

WITH THREE SPANISH MISSIONS

AT GUERRERO, COAHUILA

T. N. Campbe11

Center for Archaeological Research

The University of Texas at San Antonio

Archaeology and History of the San Juan Bautista Mission Area, Coahuila and Texas, Report No. 3

1979

Second Printing 
Center for Archaeological Research

The University of Texas at San Antonio

78285

Thomas R. Hester, Director

Archaeology and History of the San Juan Bautista Mission Area, Coahuila and Texas

This series of publications presents information gathered from archaeological investigations and historical research at the Spanish mission complex in the area of Guerrero, Coahuila, Mexico.

No. 1 (1979) Crossroad of Empire: The Church and State on the Rio Grande Frontier of Coahuila and Texas, 1700-1821. By Felix D.

Almaraz, Jr. 77 pages. $\$ 5.00+.28$ tax for Texas residents.

No. 2 (1979) Inventory of the Rio Grande Missions: 1772; San Juan Bautista and San Bernardo. Translated and edited by Felix D. ATmaraz, Jr. 70 pages. $\$ 5.00+28$ tax for Texas residents.

No. 3 (1979) Ethnohistoric Notes on Indian Groups Associated with Three Spanish Missions at Guerrero, Coahuila. By T. N. Campbell. 76 pages. $\$ 5.00+.28$ tax. for Texas residents.

No. 4 (1981) Guerrero, Coahuila, Maxico: A Guide to the Town and Missions. By Jack D. Eaton. Spanish translation by Wanda Kaufmann.

41 pages. $\$ 5.00+.28$ tax for Texas residents.

Please add postage and handling for above publications as follows: 1-2 reports, $\$ 1.25 ; 3$ reports, $\$ 1.50 ; 4$ reports, $\$ 2.00$. 
List of Tables. ...................... v

Preface ................................ vi

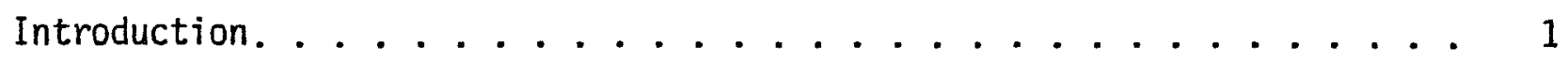

Guerrero Mission Indians. ................ 3

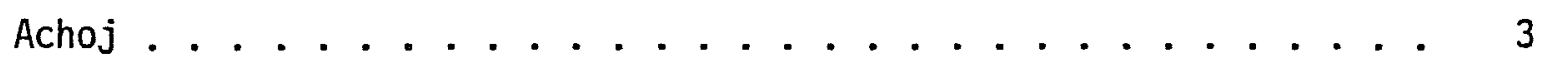

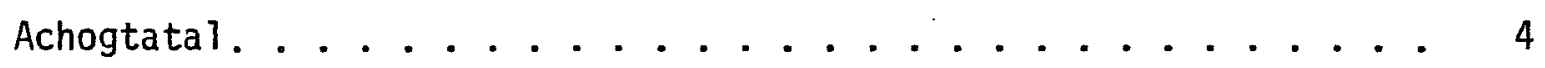

Aguayan ......................... 4

Apache. ......................... 4

Babor ........................ 4

Bacorame. . . . . . . . . . . . . . 5

Borrados. ........................ 6

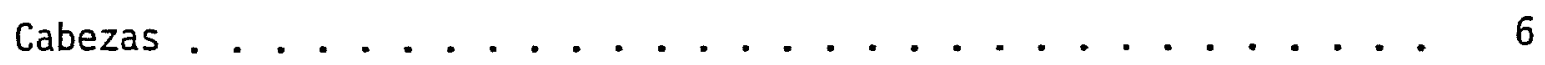

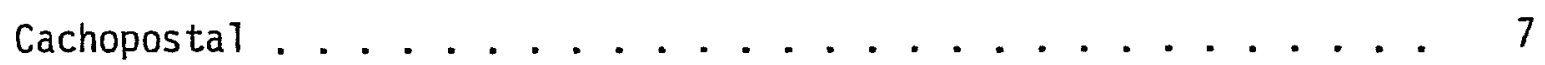

Campacuas ........................ 7

Canua .......................... 8

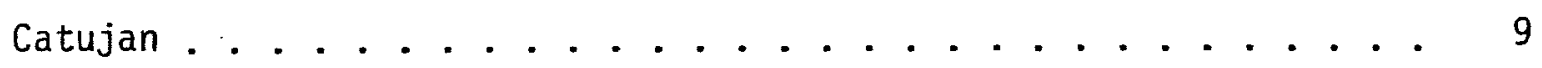

Cenizo. .......................... 9

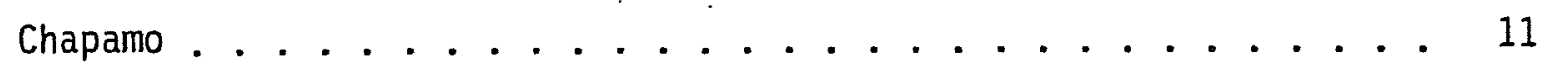

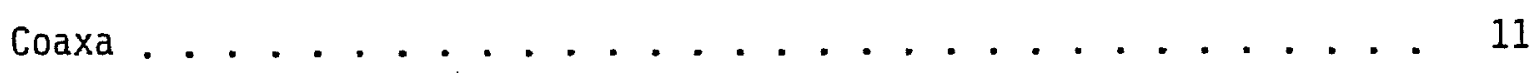

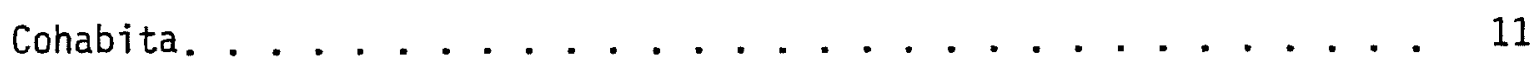

Colorados ............................... 12

Cucusa. ....................... 12

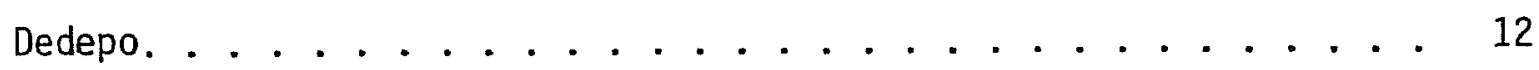

Ervipiame ......................... 13

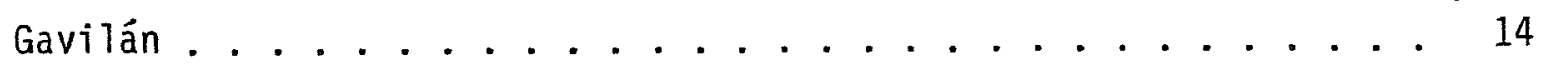


Table of Contents:

Page

Guachichil .................... 14

Gueiquesal ....................., 15

Guerjuadan ..................... 16

Hape ....................... 16

Hume . . . . . . . . . . . . . . . 17

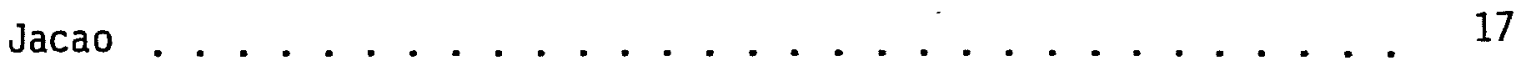

Jícaragrande ...................... 18

Juanca ........................ 18

Julime ............................ 18

Jumano . . . . . . . . . . . . . . . . 19

Macapao ........................... 19

Macocoma . . . . . . . . . . . . . 20

Malaguita................... 20

Mamuqui ................... 21

Manico.................... 21

Manos Prietas .................. 21

Matuimi .......................... 22

Maubedan. . . . . . . . . . . . . 22

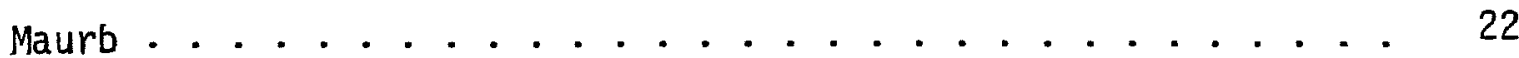

Mauyga (or Manyga). . . . . . . . . . . . 23

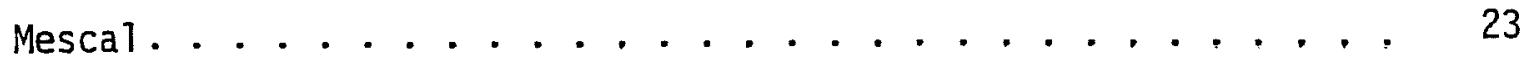

Mesquite.................... 24

Muruame ........................ 25

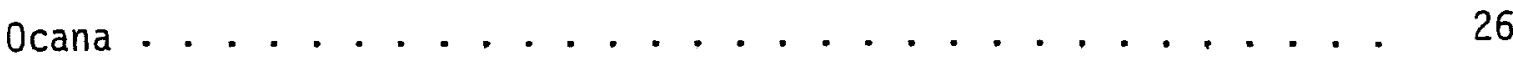


Table of Contents:

Page

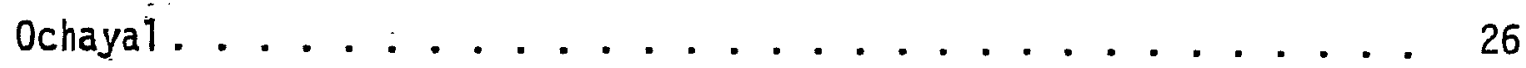

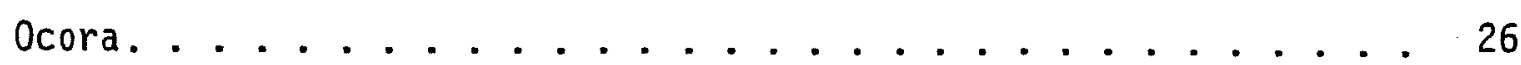

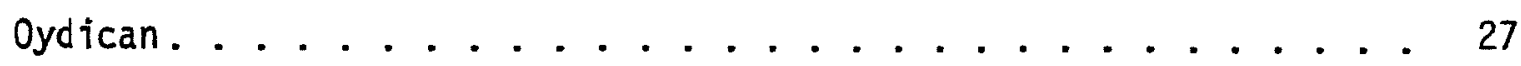

Paac ...................... 27

Pachal ......................... 28

Pachana. ....................... 29

Pacoa.......................... 29

Pacuache ................... 30

Pamajo.......................... 31

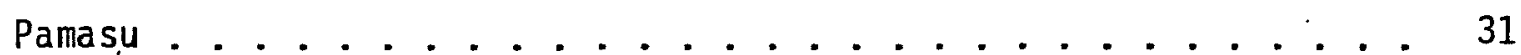

Pampopa. ....................... 32

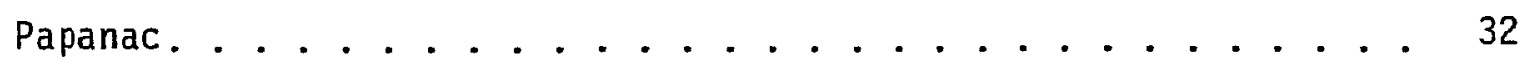

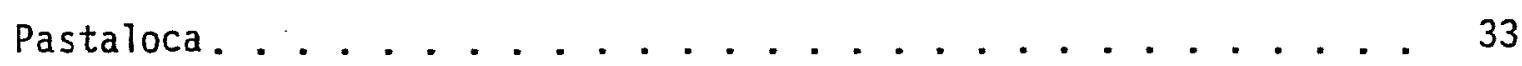

Pastancoya ..................... 35

Patacal......................... 36

Pataguo......................... 36

Patzau .......................... 37

Pausane ............................... 38

Pausaqui ....................... 38

Payaya .............................. 39

Payuguan ........................... 39

Piedras Chiquitas ................. 40

Piniquu. ................... 40

Pita..................... 41 
Table of Contents:

Page

Pitahay. .................... 42

Pitalac. ........................ 42

Pomulum. ................... . . 43

Pomuzeno ..................... . . . 44

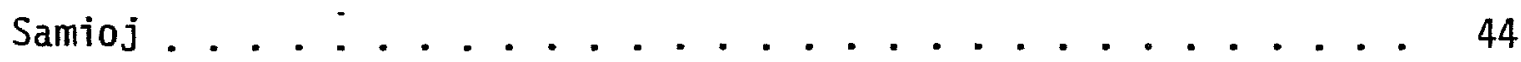

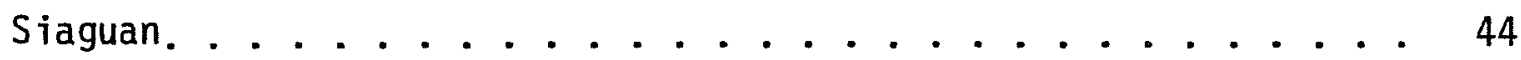

Siausi...................... 45

sijame ...................... 46

Tejas.................... 46

Tepehuan ................... 46

Terocodame ................... . . 4 47

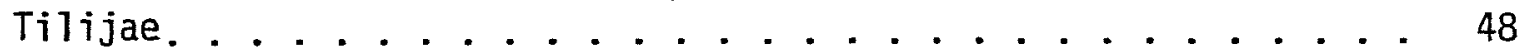

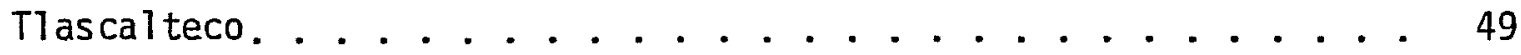

Toboso ........................ 49

Tripas Blancas ................... 50

Tumamar. . . . . . . . . . . . . . 50

Tusan....................... 51

Tuteneiboica ................... . 5 51

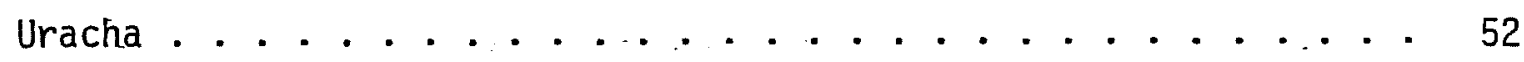

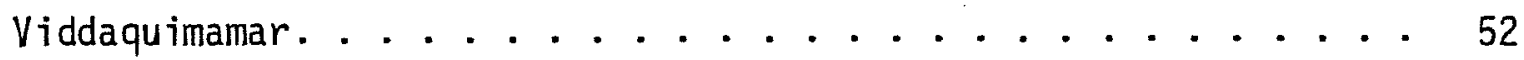

Xarame ................... 52

Yorica............................ 53

Yujan....................... 54

References Cited. . . . . . . . . . . . . 60 


\section{PREFACE}

One of the major goals of the Gateway Project was to undertake a thorough ethnohistorical study of the Indians that populated the missions of San Juan Bautista, San Francisco Solano and San Bernardo. The missions are located near present-day Guerrero, Coahuila. Earlier research had documented the presence at these missions of a number of Indian groups who were derived from what is now southern Texas and northeastern Mexico. However, the situation was a confused one, as many of the previously identified groups probably never existed, but had been "created" by well-meaning scholars who had not carefully scrutinized available ethnohistoric materials. Additionally, no intensive effort had been made to develop cultural information about any of the neophyte-groups. The generalities about "Coahuiltecans" needed to be cleared away and replaced with facts about specific, identifiable groups: who were these groups? where did they come from? what do we really know about their cultures? Early in the project, it had been hoped that a link could be established between archaeological materials from the mission Indian quarters and particular Indian groups. This has not been possible to date, although we can attribute some distinctive tool forms found in the middens where some of these groups originally lived (see Lithic Technology, Vol. VI, Nos. 1-2, p. 11) to certain parts of South Texas.

Dr. Thomas N. Campbe11, emeritus professor in the Department of Anthropology at The University of Texas at Austin, carried out the task of compiling a comprehensive study of the Indians at the Guerrero missions. The present monograph consists of essays on 88 distinct Indian groups recorded at the mission at various times during the 18th century. Dr. Campbell has also synthesized these data for publication in a book on the Gateway Project now in preparation. Dr. Campbell has made a number of significant contributions to the ethnohistory of southern Texas in recent years, and through his exhaustive archival research, we are now able to speak more confidently about specific Indian groups in southern Texas and northeastern Mexico. I believe that archaeologists, anthropologists, ethnohistorians, historians, and all who are interested in the Spanish mission system will find this monograph to be a treasury of information to which they will continually refer.

The Gateway Project was supported in large part by the National Endowment for the Humanities. Additional funding was generously provided by the Kathryn $0^{\prime}$ Connor Foundation and the Sid Richardson Foundation. Research done in Mexico was under the terms of a permit from the Instituto Nacional de Antropologia e Historia.

Thomas R. Hester December 1979 


\section{LIST OF TABLES}

Page

1. Indian Groups Represented at Guerrero Missions . . . . . . . . 55 


\section{INTRODUCTION}

Three Spanish missions, San Francisco Solano, San Juan Bautista and San Bernardo, were established near the Rio Grande at present Guerrero, northeastern Coahuila, during the years 1700-1703. Remnants of at least 88 distinctively named Indian groups at various times came to live at one or more of these missions. In 19751976, the Center for Archaeological Research, The University of Texas San Antonio, supported by funds from the National Endowment for the Humanities and the Kathryn 0 'Connor Foundation, conducted archaeological excavations at two of these missions, San Juan Bautista and San Bernardo. Since the cultural debris recovered from excavations is attributable to Indians as well as Europeans, I was asked to examine Spanish colonial documents and assemble and interpret such ethnohistoric information as could be found on the various Indian groups represented at the three Guerrero missions.

To the final report on the Guerrero investigations I have contributed a chapter entitled "Resident Indian Populations at the Guerrero Missions." In that chapter I identified the known Indian groups represented, indicated certain areas from which they had come, and made statements about their linguistic and cultural affiliations. Considerable information was collected that could not be presented in detail. In the following pages I present summaries of the information collected on each of the 88 Indian groups. Some of this information is new in the sense that attention has never been called to its existence.

Presentation of critical summaries of data collected for each of the Guerrero mission Indian groups is probably the most effective way of establishing a boundary between what is known and what is not known. Much of what is known consists of miscellaneous bits of information, often trivial in nature, haphazardly recorded by Europeans who varied in native intelligence and educational background. It is not wise to take each bit of recorded information at face value; it must be challenged in various ways before being accepted. What the following summaries glaringly show is how little can be positively stated about the culture of most of the Indian groups under consideration. As the same kinds of information were rarely recorded for many groups, it is not easy to establish notable similarities and differences. With such scant and poorly controlled data it is very difficult to make plausible generalizations.

The information on each group is segregated and arranged in alphabetical order by graup name. The table of contents may be used as an index. More detail is given, if it exists, for Indlan groups that are less well known. For groups that have already received special study, the pertinent publications are merely cited. It must be emphasized that the Indian groups covered are merely those who are known to have been represented at the Guerrero missions. Many Indian groups of the surrounding area were not reported at these particular missions. Some Indian group names recorded in documents pertaining to the Guerrero missions have not been previously reported in modern ethnohistoric literature. Whenever appropriate, attention is called to this.

Since recorded information on the Guerrero mission Indian groups is meager and widely scattered in documents, an attempt is made to identify key pages in the more important sources, both published and unpublished. The information found 
in primary sources can sometimes be interpreted in different ways, and the serious inquirer may want to evaluate the evidence independently. Secondary sources are frequently cited, especially when they contribute to interpretation of primary sources or contain stultifying errors. Numerous secondary sources, however, are not cited because, when written, they added little to what had already been said about the Guerrero mission Indians.

Variants of Indian group names that appear in the Guerrero mission registers and censuses, as wel1 as in certain other key documents, are included, but no attempt is made to present complete lists of known name variants for all groups. Sample lists are frequently included, primarily to show range of name variation and to call attention to various kinds of error.

In studies of the numerous distinctively named Indian groups of northeastern Mexico and southern Texas there has always been confusion about group names. This confusion can be greatly reduced by very detailed comparisons of names recorded in numerous documents, but the confusion cannot be eliminated entirely because some names were too infrequently recorded. There is always a residue of uncertainty. In this study of groups represented at the Guerrero missions attention is called to errors that appear in the Handbook of American Indians (Hodge 1907, 1910). Some group names in the handbook are invalid because it can be demonstrated that they are variants of other group names with separate entry status. The following 14 names should no longer be regarded as names of separate and distinct ethnic groups: Guisoles, Haeser, Hihame, Morbana, Ohaguames, Pachaloco, Pacuachiam, Pasteal, Psaupsau, Putaay, Quesal, Sinicu, Taimamares and Tusonid.

In the following summaries, information on the Indian groups at San Francisco Solano is presented in a special way that requires brief explanation. Solano was the first mission to be established at Guerrero (1700), but it remained there only about five years. In 1705, because of a water shortage problem, it was moved to a locality called San Ildefonso, some 40 miles west of Guerrero, near present Zaragoza, Coahuila. Sometime in 1708 it was moved again, this time to San José, some eight miles up the Rio Grande from Guerrero. Ten years later, in 1718, it was transferred to what is now San Antonio, Texas, where it became known by a new name, San Antonio de Valero (Solano Registers). The surviving mission registers make it possible to determine which Indian groups entered San Francisco Solano at each of its successive locations. Segregation of data according to mission locale, which is done in the summaries, permits tentative conclusions to be drawn about the pre-mission ranges of some of the more obscure Indian groups.

As so many of the Indian groups represented at the Guerrero mission were also represented at other missions of northeastern Mexico and Texas after 1690, these missions are identified. Inclusion of this information helps to document the magnitude of the disorganization and the fragmentation produced by the combined effects of Spanish and Apache displacement in this area. Some groups at the Guerrero missions were represented at as many as five, six or even seven different missions. Fragments of the groups represented at the Guerrero missions were present at a total of 23 additional missions, mainly in northeastern Coahuila and Texas. Approximately 25\% of the Guerrero groups entered other missions of northeastern Coahuila, and about $40 \%$ entered one or more of the 
five missions established at San Antonio, Texas, after 1718. Only 6\% were represented at missions of northern Nuevo León and northern Tamaulipas.

Because one of the original objectives of the study was determination of where each of the various Guerrero mission Indian groups lived before it was displaced, special attention is given to reports of where specific groups were reported as seen or otherwise said to be living under native conditions prior to mission entry.

Although population figures for specific groups rarely occur in documents, three kinds are included: (1) occasional head counts made by Spaniards in native encampments, (2) population estimates made by missionaries that refer either to Indian groups in missions or groups still living under native conditions, and (3) population figures compiled from mission registers and censuses (see Table 1). Some population figures, erroneously reported in ethnohistoric literature, are corrected.

Group intermarriage as indicated in Guerrero mission registers and censuses is noted, but frequency figures are not included. Since all mission groups were remnants of displaced populations, caution is advised in inferring aboriginal associations from these intermarriages, which were recorded at various times over a period of at least 72 years.

For relatively few Indian groups represented at the Guerrero missions is it possible to make positive statements about the language spoken prior to mission entry. Several dialects of one language, Coahuilteco, are known to have been spoken at San Juan Bautista and San Bernardo, and some speakers are identified by group names (Garcîa 1760:title page). It can be inferred, from remarks made by one of the early missionaries, Damiann Mazanet (Gómez Canedo 1968:240) that certain other groups may have spoken dialects of the same language. Beyond this, all is pure conjecture. Hence, in the following summaries, linguistic affiliation of a specific group is mentioned only when enough evidence is available to warrant some kind of statement. If nothing is said about the linguistic affiliation of a group, this may be taken to mean "language unknown." Aithough they have minimal linguistic value because meanings are not given, the few native personal names recorded in mission registers and censuses are included.

Cultural information is included only when it can be safely attributed to a specific ethnic unit. No attempt is made to relate the summarized cultural information to Ruecking's "Coahuiltecan ethnography," which is a demonstrably invalid construct (Ruecking 1953, 1954b, 1955b).

\section{GUERRERO MISSION INDIANS}

Achoj. In the census taken at Mission San Juan Bautista in 1772, three adul.t males are identified as "Achoj," one adult female as "Achogtatal," and one adult male as "Ochayal" (Rodriguez 1772b:125-127,129). Evidently, the five individuals arrived at San Juan Bautista sometime after the census of 1734, which failed to record them. These names may refer to one, or two, or even three ethnic units. Only in documents of southern Coahuila are somewhat similar names recorded. These southern Coahuila documents were written mainly 
between 1600 and 1640 and include such names as Oche, Ooche and Ocho (Griffen 1969:164,171; Martinez del Rio 1954:54). This suggests that the group (or groups) represented by these Achoj, Achogtatal and Ochayal individuals may have originally lived somewhere in southern Coahuila.

\section{Achogtatal. See Achoj.}

Aguayan. This name, also twice rendered as "Aguayam," appears only in the census taken at Mission San Bernardo in 1772 (Rodriguez 1772a:65,68-73). The Aguayan population at that time consisted of 11 individuals: 6 adult males, 2 adult females, and 3 children, 1 male, 2 female. An identity for this population has yet to be established. Earlier documents of this and adjoining areas do not refer to an ethnic group with a name similar to Aguayan. It may be a late distortion of the name Payuguan, which was not recorded in the 1734 and 1772 censuses of San Bernardo. Espinosa (1746:483), however, mentions that some Payuguan were at San Bernardo in its earlier years. Whoever the Aguayan were, they evidently arrived at San Bernardo sometime between 1734 and 1772 .

Apache. The Apache were enemies of most of the Indian groups represented at the Guerrero missions, and the few Apache individuals reported were probably captives taken by efther Indians or Spaniards during the pre-mission and early mission periods. Of the seven Apache individuals indicated in the San Francisco Solano records, five are children, ages three to nine, without parents (Solano Registers). The singhe Apache identified in the 1734 census taken at San Juan Bautista was an elderly female (Garza Falcón 1772b:18). All these persons are identified simply as "Apache," without any indication of affiliation with a specific Apache sub-group.

Babor. At least 30 individuals can be identified as Babor in the San Francisco Solano baptismal register for the years 1706-1707, when the mission was at San Ildefonso, some 40 miles west of Guerrero. These are referred to by three names, "Babor," "Bobor," and "Pabor," all presumably synonymous. One individual is listed in one entry as "Babor" and in another as "Bobor" (Solano Registers). Hodge (1910,II:182) has referred to these under the name "Pabor." Of the 30 individuals, 9 are adult males, 7 are adult females, and 14 are children, 7 male and 7 female, the ages ranging from 1 to 9 years. Few spouses are ethnically identified: other "Babor" or "Bobor," "Juman" (Jumano), and "Terocodame."

Circumstantial evidence seems to indicate that the Babor of San Francisco Solano were the same people as those frequently referred to in other documents as "Bob01." A number of similar names are probably synonymous, among them Babel, Babola, Baboram, Baburi or Babury, Bobo, Boboram, Bovol, and Pabori. The presumed population was known at least as early as 1665, and for some 30 years thereafter was occasionally reported at various localities in northeastern Coahuila and the closely adjoining part of Texas, but particularly along the Rio Sabinas and the Rio Grande west and northwest of present-day Guerrero. Maps prepared by Jimênez Moreno (1944) and by Driver and Massey (1957) show "Boboles" within the area designated here, but the map of Ruecking (1955a) places the "Bobole" so far to the south in eastern Coahuila that they are not near the Rio Grande or north of it. One reason why the Babor are so frequently mentioned in documents is that 
prior to 1700 they were usually friendly toward Spaniards and sometimes joined them on exploratory and punitive expeditions northward toward the Rio Grande and beyond. Most of the details can be found in the following published sources: Alessio Robles (1938), Bolton (1916), Castañeda (1936,I), Figueroa Torres (1963), Griffen (1969), León y otros (1961), Portillo (1886) and Steck (1932).

The Babor entered other missions, but none of these were located to the east of Guerrero in southern Texas and northern Nuevo León. All were in the vicinity of modern Monclova, the principal ones being San Miguel de Aguayo and Santa Rosa de los Nadadores (Griffen 1969:56-57; Porti110 1886:247,251). At least 49 "Bobol" were still living at San Miguel de Aguayo as late as 1762. The Babor thus seem to have gone to missions that were nearest to their original territory.

Some cultural information can be gleaned from several sources (Bolton 1916:305; Figueroa Torres 1963:67,104-107,114-115; León y otros 1961:147-149). Most of the details involve both the Babor and various groups associated with them. Settlements were temporary and were placed near springs and flowing streams, usually in a wooded spot. Most encampments were shared with other groups. House form is not described, but one structure, apparently built by Indians for missionary use as a chapel, is said to have been made of poles covered with grasses. It is specifically stated that horticulture was not practiced. Fruits and roots were gathered, including the root crown of the maguey plant. Deer and bison were hunted, the latter especially north of the Rio Grande. Fishing was done in the Rio Grande and other perennial streams of the area. A limited amount of cannibalism is said to have been connected with warfare. In smallpox epidemics at early temporary missions, the Babor and their associates reacted by dispersing themselves in the surrounding area.

Bacorame. In 1706, when San Francisco Solano was located at San IIdefonso, some 40 miles west of Guerrero, eight individuals (three families) were identified as Bacorame (written once as "Barocame," evidently the result of transposing consonants). Of these eight persons, two are recorded as adult males, three as adult females, and three as male children, ages two to five. Spouses are identified as other Bacorame (Solano Registers). These Bacorame appear to be the same people as those who, in earlier documents (1674-1688), are referred to by such names as Bacora, Bacaran, Bacaranan, Bascoram, Basioram, Bocora and Bocore (Alessio Robles 1938:219,232; Bolton 1916:305-306; Figueroa Torres 1963:61-62, 77-78,119; Griffen 1969:38,53,88,156). The Bacorame can be attributed to an area that extended northward from Monclova to the vicinity of present-day Del Rio, Texas, but especially between the Rio Sabinas and the Rio Grande east of the mountain front. In 1675 Bosque visited a "Bacora" encampment that by actual head count included 150 individuals--62 men and 88 women and children (Bolton 1916:305-306). The camp was said to have been in a wooded area near springs and also near a stream called "Nueses," which Bolton suggested might be the modern Río de San Diego of northeastern Coahuila. The encampment locality was probably somewhere south of Del Rio.

A few details on the culture of the Bacorame are given by Figueroa Torres (1963: 77). His "Basioram" (possibly a misreading of handwritten "Bascoram") and their associates (16 groups named) were said to eat roots, acorns and bison meat. A 
clue to housing is provided by a missionary's statement that for over 100 years these Indians had kept a cross in a round hut (choza) covered by dressed bison hides. The detalls imply extensive bison hunting, which helps to identify their area with northeastern Coahuila east of the mountains, where the earliest documents report bison hunting by both Indians and Spaniards. Other sources (Griffen 1969:53,58) indicate that the Bacorame participated in various Indian rebellions of central Coahuila, and there are references to horse theft and death attributed to witchcraft by a specified "Bacorame" male. One Indian enemy group is identified, the "Irbipia," evidently the Ervipiame.

Borrados. In 1767 Borrados were mentioned as being represented among the 33 families of Indians then living at Mission San Juan Bautista (Kinnaird 1958:187). This is confirmed by two "Borrado" individuals, both adults, one male, the other female, noted in the census of 1772 taken at that mission (Rodriguez 1772b:128129).

The Borrados of San Juan Bautista almost certainly came from the southeast. Borrados is a Spanish word, probably best translated here as "smeared with ink," that was used in Nuevo Leôn and parts of Tamaulipas to refer to Indians who painted or tattooed their bodies in patterns that involved closely spaced parallel lines (Hoyo 1972:2). In Spanish documents a specific group was sometimes referred to by the Spanish name alone, sometimes by the name Borrados in conjunction with a native group name. Apparently no one has yet attempted to complie a list of native-named groups that were also referred to as Borrados. Such a list would be helpful.

Groups referred to as Borrados seem to have been extensively displaced by Spaniards during the eighteenth century. Remnants entered numerous missions in Nuevo León and Tamaulipas, but some moved northward across the Rio Grande to live near the coast in southern Texas. It was some of these coastal Borrados who entered San Antonio missions, particularly Nuestra Señora de la Purisima Concepciôn de Acuña and San Francisco de la Espada (Concepción Marriage Register 1767; Cabe110 1780b:37-38; Dolores 1762a:52 and 1762b:171,178b).

The name Borrados was also used by Spaniards in southern and western Coahuila, as well as in Chihuahua (Griffen 1969:57,156,172-174), but apparently the Borrados of San Juan Bautista and the San Antonio missions were not of western origin.

Cabezas. The name Cabezas is Spanish for "heads." The census of 1734 at San Juan Bautista identifies four individuals, a man and his three children, as "Cavezon" or "Cavezos" (indistinct handwritting), almost certainly a variant. of the name Cabezas (Garza Falcon 1734b:16). Griffen (1969) has summarized data from numerous documents that pertain to the Cabezas and has given their pre-mission territory as probably southern Coahulla, particularly between Monclova and Parras. It is evident that by 1700 the Cabezas were represented only by remnants that had-survived the extensive. Spanish-Indian hostilities of seventeenth-century Coahuila. 
Cachopostal. Nearly all references to the Cachopostal can be traced back to a single documentary source, the report of Sevillano de Paredes (1727:42-43), which was written in 1727 during his inspection of missions near the Rio Grande at modern Guerrero. In this report the "Cacho Postal" are said to be few in number and living very close to the Pampopa on the Nueces River some 55 to 60 miles east of the Rio Grande missions. Direction, distance and identification of the river suggest that in 1727 these Indians were living in the area now covered by eastern Dimmit and western La Salle Counties, Texas. Since most secondary sources have combined "Cacho Postal" into "Cachopostal or "Cachopostale," the combined form is used here. Clerical and typographical errors have led to two additional variants: "Cachopostate" (Powell 1891:69) and "Cacahapostal" (Webb $1952, I: 263$ ).

So far as is now known, the Cachopostal entered only one Spanish mission, San Juan Bautista, for which the census of 1772 identifies four individuals: two adult males, one adult female, and one male child (Rodriguez 1772b:123-127). In this census the name is rendered in two slightly different forms, "Cachsaputal" and "Cachsopota1." The adult female, it may be noted, was married to a Pampopa. The suggestion (Branda 1976:132) that the Cachopostal may have been the same as the Postito recorded at Mission San José y San Miguel de Aguayo of San Antonio, Texas, may be disregarded. Postito seems better interpreted as an Hispanicized diminutive form of the name Pastia.

Close association of the Cachopostal with the Pampopa, who are believed to have spoken a dialect of Coahuilteco, suggests that the Cachopostal may also have spoken the Coahuilteco language.

Campacuas. The name Campacuas, also rendered as "Campaguas," "Canpacuas," and "Canpaguas," appears in the San Juan Bautista census report of 1772, in which 14 individuals are so identified (Rodriguez 1772b:124-126,128-129). Of these, two are adult males, eight are adult females, and four are children, one male and three female. Identified spouses include "Panpopa" (Pampopa), "Pataloco" (Pastaloca) and "Payaya." Records pertaining to the area west of Guerrero contain no similar group names, but records connected with areas farther east, dating after 1780, refer to a group whose name is variously rendered as Campacues, Campaquases, Tanpacua, Tanpaquazes, Tanpaqueces and Tompacuas, for which Hodge (1910,II:687) has used the name "Tanpacuazes." The Guerrero names and the eastern names undoubtedly refer to the same ethnic group.

In 1780 Cabel10 (1780a:37) wrote that the "Tanpacauses" were one of 10 Indian groups then ranging an area near the Texas coast between the Nueces River and the Rio Grande. Some of these survived well into the nineteenth century in northern Tamaulipas. In 1834 Berlandier (mis., III:843-846) reported "Campacues" still surviving near Reynosa, Tamaulipas, and stated that they, along with other ethnic group remnants of the area, lived by hunting and gathering, particularly during the summer months. Foodstuffs mentioned include deer, rats, roots, prickly-pear fruits, and mesquite beans. In 1853 "Tanpaquash" and "Carcese" (Carrizo) were said to be raiding settlements north of the Rio Grande somewhere downstream from Laredo (Winfrey and Day 1966, III:261-263). In 1886 Gatschet found that the "Tampakua" were remembered by surviving speakers of the Comecrudo language living near Camargo, Tamaulipas (Swanton 1940:5,103). 
Until recently this ethnic group name survived in two place names of Hidalgo County, extreme southern Texas: "Tompacuos," a town, and "Tampaguas," a lake (MacManus 1885:map; Trowbridge 1923:map). Parisot and Smith (1897:39) have referred to "Campacuas" as a name recorded in the registers of unspecified San Antonio missions, but this has yet to be verified. Gatschet (1891:44,50-51) once suggested that the name "Tampacua" may have referred to the Karankawa, a connection that has not been substantiated.

The bulk of the evidence indicates that the Campacuas of San Juan Bautista were refugees from an area that extended northward an unknown distance from that section of the Rio Grande which lies downstream from Camargo (Tamaulipas) and nearby Rio Grande City (Texas). It does not appear that this group ranged very far south of the river.

Canua. The Canua, also recorded by such similar names as Cana or Canna, Cano, Canoa and Canon, appear to have ranged over a fairly large area that included the more easterly portion of northeastern Coahuila, northern Nuevo León, and adjoining parts of the South Texas Plain across the Rio Grande.

The earliest reference to the Canua is provided by Cuervo y Vaidês $(1700 a: 11,16)$, who identified "Canua" as one of five Indian groups represented at the foundation of Mission San Felipe (or Santiago) de Valladares in 1700 near present Candela of eastern Coahuila. Three years later, when Mission San Bernardo was established near present Guerrero, the name "Canuas" was entered on a list of 12 Indian groups recorded as present (Ximënes 1762a:112-113; Morfi 1935b:231).

In 1708 Espinosa cited the name "Canoas" on a long list of Indian groups then living across the Rio Grande in a generalized easterly direction from Mission San Bernardo (Maas 1915:36). In the same year San Buenaventura y Salazar (ibid.:23), evidently referring to a time several years prior to that date, listed "Canoas" as one of nine groups, all speaking the same language (not identified), that lived along the Rio Grande both upstream and downstream from present-day Laredo, and frequently visited and traded at Mission Nuestra Señora de los Dolores near modern Lampazos of northern Nuevo León. These records of 1708 show that in the early eighteenth century some of the Canua were still living under aboriginal conditions on both sides of the Rio Grande well downstream from Guerrero.

In a document of 1713 the name "Canos" appears on a list of four Indian groups from the north side of the Rio Grande that had been persuaded to enter Mission San Bernardino de la Candela near present Candela, Coahuila (Bolton 1913:423; Rivera y Villalón 1945:126,131). At some unspecified time after 1720 "Canas" are said to have entered Mission San José y San Miguel de Aguayo of San Antonio, Texas (Forrestal 1931:20; Morfi 1935a:98). The Durán map, compiled prior to 1744, is probably based on information derived from early eighteenth-century sources. On this map the designation "105 Canas," which may refer to the Canua, is entered in an area southwest of San Antonio (Durán 1744).

It is not known just how many Canua became residents of the various Spanish missions noted above. The only informative records are the Mission San Bernardo censuses for the years 1734 and 1772. The census of 1734 identifies only one Canua individual, an adult male named Antonio, who is referred to as a "Canon" (Garza 
Falcón 1734a:21). The census of 1772 identifies four "Canoa," two adult males and two adult females, one of the males being named Antonio, possibly the same Antonio earlier referred to as a "Canon" (Rodriguez 1772a:65-66,72).

A number of errors pertaining to the Canua require correction. The Canua of Mission San Bernardo are given as "Cahuas" by A. L. Velasco (1897,XIX:14) and as "Camisas" by Naranjo (1934:56), both evidently errors of transcription or printing. Hodge (1910,II:1035) gives the name "Cana" as a synonym of Sana, but no evidence has been found which supports this judgment. Martin (1947:26) has mistakenly equated Canua with Ocana. Spanish documents consistently make a distinction between Canua and Ocana, both names sometimes appearing on the same compiled list of Indian groups.

Although the record, as summarized above, seems sufficient to establish an identity for the Canua, this ethnic unit seems to have been overlooked by many modern scholars. Hodge, as noted, considered the name "Cana" to be synonymous with Sana. Since Swanton (1940, 1952) and Ruecking $(1954 a, 1955 a)$ followed the lead of Hodge, they paid no attention to the Canua.

Catujan. In various documents the name Catujan occurs in a number of readily recognizable variants: Catujane, Catujano, Catajane, Catjuano, Catujan, Catuxan, Catuxzan and Cotujan. Nearly all early references to the Catujan, beginning about 1650, place them south of the Rio Grande in extreme northeastern Coahuila and northern Nuevo León (Alessio Robles 1938:199,232,238,249,272; Bolton 1916: 304; Cavazos Garza 1964:190; Figueroa Torres 1963:102,105,122; León y otros 1961:189-190; Rivera y Villalón 1945:126). In 1675, however, one missionary reported some of the Catujan north of the Rio Grande, apparently in a general northerly direction from Guerrero (Figueroa Torres 1963:105), and this may mark the northern boundary zone of their pre-mission territorial range. Near the Coahuila-Nuevo León boundary, just west of Lampazos, Nuevo León, is the Mesa de Cartujanos (or Catujanos), which is said to derive its name from the Catujan Indians (Alessio Robles 1938:199; González 1885:252-253). The maps of Jimenez Moreno (1944) and Ruecking (1955a) place the Catujan within the area described above.

The Catujan have been identified with the foundation of Mission San Bernardo in 1703 (Ximénes 1762a:112), and this is confirmed by the censuses of 1734 and 1772. In the 1734 census two "Catujan" are identified at San Bernardo: an adult male and his three-year-old daughter (Garza Falcón 1734a:21). In the census of 1772 (Rodriguez 1772a:67-68), five "Catujan" and "Catujam" are identffied: two adult males, one adult female and two male children. The spouses are given as other "Catujan" and "Ocan" (Ocana). Some Catujan were also at other missions south and southwest of Guerrero: San Bernardino de 1 a Candela of eastern Coahuila (Rivera y Villalón 1945:126) and San Miguel de Aguayo near Monclova, Coahuila (Portillo 1886:251).

Cenizo. The ethnic name Cenizo is evidently of Spanish origin, its basic meaning being "ash" or "ashes." A native name for this Indian group may appear in Spanish documents, but as yet no linkage clue has been found. A widely distributed shrub in northeastern Mexico and southern Texas is known by the Spanish name ceniza (or cenizo), known in Texas as Texas silverleaf or purple sage 
(Gould 1962:80). It is doubtful if there is any etymological connection between the Spanish name for the plant and the ethnic name Cenizo. Hodge (1910,II:509) has alluded to a possible relationship between the ethnic name and the "white goose-foot," a plant also said to be known as cenizo.

Such evidence as is available indicates that the pre-mission territorial range of the Cenizo was in extreme northern Nuevo Leon and the adjoining part of northwestern Tamaulipas, particularly between Lampazos, Nuevo León, and the Rio Grande both above and below modern Laredo, Texas (Maas 1915:16-23). How far north of the Rio Grande the range may have extended is unknown.

The Cenizo seem to have been first recorded in 1698 as one of five Indian groups represented at Mission San Antonio Galindo Moctezuma when it was founded (Portillo 1886:265-269). This mission was some 25 miles north of Monclova, near the junction of the Coahuila and Nadadores rivers. All five groups were said to be refugees from the northern frontier of Nuevo León who had repeatedly fled from an encomentero of that region. The mission did not last very long because of pressure from local Spanish settlers and attacks from hostile Coahuila Indians identified as Toboso (Alessio Robles 1938:372373; Morfi 1856:424-425).

Six "Zenizo" are identified in the baptismal register of San Francisco Solano for the year 1706, when this mission was located at San Ildefonso. Included are two adult males and four children, one male and three female, ages four to ten. Spouses of the adult males are listed as "Gabilan" and "Ocana" (Solano Registers).

A few Cenizo ended up at Mission San Antonio de Valero, San Antonio, Texas. In various mission register entries between the years 1720 and 1739 four individuals are identified by group names that appear to be variants of the name Cenizo (Valero Registers). These are alphabetically listed below:

$\begin{array}{ll}\text { Ceniso } & \text { Senixso } \\ \text { Ceniza } & \text { Senixzo } \\ \text { Censoc } & \text { Senizo } \\ \text { Censoo } & \text { Sinico } \\ \text { Saczo } & \text { Sinicu } \\ \text { Senicso } & \text { Siniczo } \\ \text { Seniczo } & \text { Sinixzo } \\ \text { Seniso } & \text { Zenizo }\end{array}$

Hodge (1910 II:70,426) identified one of these, "Sinicu," as the name of a separate Indian group, and this was followed by Swanton (1940:135) but not by Ruecking (1955a).

Remnants of the Cenizo survived in northeastern Mexico well into the latter half of the eighteenth century. In 1752 Cenizo were noted in northwestern Tamaulipas near the present Falcon Reservoir on the Rio Grande (Saldivar 1946:88-89), and in 1777 some were recorded in northern Nuevo León near modern Vallecillo (Gonzålez 1885:256-257). 
Chapamo. This name appears onty in the report of the 1772 census taken at Mission San Juan Bautista. Two individuals are identified as "Chapamo," a man and his adult son (Rodriguez 1772b:127). A similar name, "Chapamaco," is mentioned in a document of 1708 written by Espinosa (Maas 1915:36-37), who includes it on a list of Indian groups said to be living north of the Rio Grande but in an easterly direction from the Guerrero missions. Although the documents are separated by more than 60 years, the two names are probably synonymous.

Bolton (in Hodge 1910, II:426) reported "Chapamaco" as occurring in the registers of Mission San Antonio de Valero at San Antonio, Texas. Inspection of these registers reveals that a woman known both as Rosa Maria and Juana Rosa, who lived at San Antonio de Valero between 1732 and 1748, was identified as Chapamaco twice and as Secmoco seven times (Valero Registers). This suggests that Chapamo, Chapamaco and Secmoco may be variants of the same group name. Hodge (1910, II:426,494,575-576,1136), Swanton (1940) and Ruecking (1955a) are probabiy incorrect in assuming that the names Chapamaco and Secmoco refer to separate groups.

All that can be said about the Chapamo is that their territorial range, as indicated by Espinosa, was somwhere in lower Texas east of Guerrero and south of San Antonio. The name Chapamo superficially resembles the name Siupam, but the two names evidentiy refer to separate ethnic units, since Espinosa's i ist of south Texas groups in 1708 includes both "Chapamaco" and "Xipam," the latter almost certainly referring to the Siupam.

Coaxa. One Coaxa individual, a four-year-old female, was baptized at San Francisco Solano in 1707, when the mission was located at San Ildefonso (Solano Registers). The pre-mission territory of the Coaxa remains uncertain, but association with San Francisco Solano at its San Ildefonso location suggests an area northwest of Guerrero. Coaxa might be a variant of the name Cuaguila (Coahuila), a term often used by Spaniards to refer collectively to Indians of that province (Griffen 1969:159).

Two somewhat similar names appear in Spanish records, but the evidence is insufficient to relate them to Coaxa. Each name is known from a single primary document. The first is Coayo, the name of a group briefly encountered by Nuñez Cabeza de Vaca $(1542: 38 a)$ in the prickly-pear fields of. southern Texas in 1535, about 170 years before the name Coaxa was recorded at San Francisco Solano. The second is Cuajin; the name of an Indian group known to Juan Jarri (Jean Gery), a Frenchman who deserted the La Salle expedition (1685-1687) and made his way westward from Matagorda Bay to live among the Indians of southern Texas. He was taken into custody by Spaniards north of present-day Guerrero in 1688 (León y otros 1961:219). Just where in southern Texas this Frenchman encountered the Cuajin cannot be determined.

Cohabita. One adult male "Cohabita" is identified in the baptismal register of San Francisco Solano in 1707, when the mission was at San I7defonso. This man is listed as a Christianized Indian who was in charge (en su poder) of a five-year-old Apache girl that was being baptized, presumabiy a captive he 
had adopted (Solano Registers). The name Cohabita is referable to a population, elsewhere recorded as Cocobipta and Cucubipi, that originaliy ranged over parts of northern Coahuila and northeastern Chihuahua. In the late seventeenth century this group is named among others that habitually crossed the Rio Grande below the mouth of the Pecos River to hunt bison in winter (Griffen 1969:88,93-94,158-159,177; Hackett 1926,II:395; Porti110 1886:77-78). In 1793 Revilla Gigedo (1966:60) reported "Cocobipta" as still present in one or more unspecified Coahuila missions.

Colorados. In 1706, when San Francisco Solano was at San Ildefonso, one adult female was identified as "Colorados" in the baptismal register. She was married to a "Cucusa" (Solano Registers). Griffen (1969:passim) has described the role of the Colorados in various Indian rebellions of western Coahuila during the seventeenth century and considers their range to have been in central Coahuila, particularly the area southwest of Monclova (ibid.:140). Some of the Colorados entered other missions in Coahuila prior to 1700 . They were at Parras (as early as 1629), at San Buenaventura de las Cuatro Ciénegas near modern Cuatrociénegas, and at San Miguel de Aguayo of Monclova (ATessio Robles 1938:269-270,305,530; Griffen 1969:157-158; Porti110 1886:251,405-406). They seem to have maintained an ethnic identity in Coahuila missions as late as 17.67 (Kinnaird 1958:154).

One female referred to as de la nación. Colonado, married to a "Payaya," is recorded (1720) in the baptismal register of Mission San Antonio de Valero of San Antonio, Texas (Valero Registers). The Spanish name of this group is most often recorded in the plural form and is perhaps best translated as "reddish people." The Colorados of Coahuila may or may not be the same as the colorados of the Rio Conchos in Chihuahua.

Cucusa. Ten Cucusa individuals are recorded in the baptismal register of San Francisco Solano for the years 1706-1707, when the mission was at San Ildefonso (Solano Registers). Of these, 3 are adult males, 1 is an adult female, and 6 are children, 3 male, 3 female, whose ages range from 1 to 10 years. The six children are linked with the adult males. A native name, Ysmague, is recorded for one female child. Spouses are identified as "Colorados," "Macocoma," and "Terocodame." These Cucusa of San Francisco Solano are probably the same people referred to as "Cocuytzam," who in 1674 were 1 isted as one of many groups known to Spaniards of central Coahuila (Alessio Robles 1938:232). Such evidence as is available suggests that the Cucusa lived somewhere to the west or northwest of modern Guerrero.

Dedepo. The registers of San Francisco Solano do not identify any Dedepo, but Espinosa (Maas 1915:35; Weddle 1968:54) clearly stated that some Dedepo were present when that mission was located at San IIdefonso. Various accounts of Indian raids and rebellions suggest that originally the Dedepo (the name is occasionally rendered as Idedepo) lived somewhere in central Coahuila (Alessio Robles 1938:232; Cuervo y Valdês 1698:6; Griffen 1969:33,88,90). 
Ervipiame. The name Ervipiame, which appears in both Spanish and French documents, has been rendered in an astonishing number of ways. At least 84 orthographic variants have been collected, among which are Barbipian, Berttipane, Chivipane, Erbipiamo, Etiepen, Gueripiamo, Heruipiane, Hierbipiam, Hyerbipiana, Irripian, Jerbipiam, Yeripiame, Yrbipia and Yurbipian.

The Ervipiame became known to Spaniards during the period 1670-1688, when they were reported as being hostile to Spaniards and other Indian groups of northeastern Coahuila and the adjacent part of Texas (Bolton 1916:297; Griffen 1969: 19,88,90,160). In 1700 a short-lived mission, San Francisco Xavier, was established for about 200 "Yerpiames" near present Villa Union, Coahuila (Bolton 1913:422; Cuervo y Valdés 1700a:12,16; Portilio 1886:269-271). In the same year Ervipiame were said to be causing trouble for Mission San Juan Bautista (Weddle 1968:42-43), indicating that some Ervipiame probably had not entered San Francisco Xavier.

In 1706, when Mission San Francisco Solano was at San Ildefonso, three "Hyerbiptan" were identified in the baptismal register: one adult male, one adult female, and one male child, age three (Solano Registers). Two years later, in 1708, Espinosa reported "Yervipianos" as one of the Indian groups then living north of present Guerrero, somewhere between the Rio Grande and the southern margin of the Edwards Plateau (Maas 1915:36-37). Apparent7y sometime after 1708 most of the Ervipiame migrated northeastward to east-central Texas, although a few may have entered San Juan Bautista. One adult male "Yorivipramo" is identified in the San Juan Bautista census of 1734 (Garza Falcón 1734b: 15).

As noted above, the Ervipiame, along with remnants of various groups from northeastern Coahuila and vicinity, moved into the area northeast of present Austin, mainly between the Colorado and Brazos Rivers. This move seems to have been prompted by a desire to escape from both Spanish and Apache pressures. After 1708, Spanish and French traveling parties often passed through the new Ervipiame territory, and some documents refer to a large aggregation of Indians known as Rancheria Grande, made up of the migrants and some Indian groups native to that area (Bolton 1914:329-331 and 1915:143-145; Hodge 1910, II:354). The Ervipiame seem to have provided leadership for the Rancheria Grande assemblage.

By 1720 at least some of the Ervipiame were willing to enter a mission at San Antonio. In 1722 a new mission, San Xavier de Naxera, was initiated at San Antonio, primarily for the Ervipiame and their associates-from Rancheria Grande, who were led by a chief known as Juan Rodriguez. They were assembled at the locality where Mission Nuestra Señora de la Purisima Concepción de Acuña was later established in 1731. The Indians remained at this locality until 1726, being served by missionaries from nearby Mission San Antonio de Valero, and this is indlcated by a separate set of registers which cover the period from March 12, 1721 to April 20, 1726 (Valero Registers). As no structures were ever built at San Xavier de Naxera, the Indians were incorporated into the Valero establishment (Bolton 1907:298-301,303 and 1915:144; Forrestal 1935: $10,18,61$; Hodge $1910, I I: 354,458)$. In the combined registers of San Antonio de Valero and San Xavier de Náxera at least 101 Ervipiame individuals can be identified between the years 1720-1770. The registers make it clear that many of these Ervipiame were from Rancheria Grande. 
In 1748 Mission San Francisco Xavier de Horcasitas was established as one of three missions on the San Gabriel River of present Milam County, Texas, which was within the range of the earlier Rancheria Grande Indians (Bolton 1914). In a mission census of 1750 (Dolores 1750:48-49), 36 "Hierbipian" were identified at San Francisco Xavier. Some of these may have been at San Antonio earlier, but it appears that others were Ervipiame who had never left Rancheria Grande. By 1752 this mission had begun to disintegrate, and it was finally abandoned in 1755 . Some of its Indians went to San Antonio missions, but others remained in the area and afterward were occasionally referred to as Ervipiame associated with Tonkawa.

Bolton (in Hodge 1910,II:778) assumed, but did not prove, that the Ervipiame spoke a Tonkawan language, and this has been widely accepted (Hoijer, in Webb 1952, II:778; Sjoberg 1953:281-282,300-303). No sample of Ervipiame speech seems to have survived, and Bolton's argument for Tonkawan affiliation is debatable. It is doubtful if the linguistic status of the Ervipiame will ever be determined.

Gavilän. In the baptismal register of San Francisco Solano, mainly for the years 1706-1707, when the mission was at San I1defonso, 14 individuals are identified as "Gabilan" (Solano Registers). Gavilán is a Spanish name ("sparrow hawk"). Of these 14 Gavilán, 2 are adult males, 10 are adult females, and 2 are children, both male, ages 2 and 6 . Two female names may be of native origin, Masuriba and Masudradre, the latter indistinctly written. Spouses are identified as other "Gabilan," "Mauyga" (or "Manyga"), "Terocodame," "Ticmamar" (Tumamar), and "Zenizo" (Cenizo). Griffen (1969:passim) has summarized Gaviián-Spanish relations in the seventeenth century and places the original Gavilan territory in western Coahuila and closely adjacent parts of Chihuahua and Durango. The Gavilán of San Francisco Solano seem to represent remnants displaced eastward that managed to survive into the early eighteenth century. The presence of Gavilan at San Francisco Solano is confirmed by other documents that refer to the earliest years of the mission (Maas 1915:25,35; Weddle 1968:54-55).

Guachichil. In 1716, when San Francisco Solano was 1ocated at San José, about eight miles from Guerrero, one adult male was identified in the marriage register as a "Guacacil." At the time he was serving as governor of the mission Indian village (Solano Registers). In 1772 at least 12 individuals were identified as "Huacacil" and "Guachasil" in the census report for Mission San Bernardo (Rodríguez 1772a:65-66,69-70,72). Of these, 3 are adult males, 2 are adult females and 7 are children, 4 male and 3 female. Spouses are 1isted as "Aguayan," "Pacó" (Pacoa), "Pamulien" (Pomulum) and "Paquachi" (Pacuache).

The presence of a few Guachichil at these northeastern Coahuila missions is not surprising. The Guachichil (this name is also variously rendered as Cuachichil, Guaxchil, and Huachichil) originally occupied a large area that extended from southern Coahuila and southern Nuevo León southward to the northern boundary zone of Mesoamerica (Jiménez Moreno 1944:map;1958). These Guachichil were broken up as the Spanish frontier moved northward in the sixteenth century, and surviving remnants also moved northward with the Spaniards or ahead of them. Early records of both Coahuila and Nuevo León indicate presence of Guachichil in various parts of northeastern Mexico (Alessio Robles 1936; Cavazos Garza 1966a,b; González 1885, 1887; Hoyo 1963, 1972; León y otros 1961; Porti110 1897). Although the Guachichil language has frequently been 
classified as Uto-Aztecan, this is not based on studies of recorded speech samples, and opinions about its status have been varied, as is shown by the foll lowing sources: Gursky (1964); Jimenéz Moreno (1958); Johnson (1940); León (1901); Mason (1940); and Swadesh $(1959,1967)$.

Gueiquesa1. This name has been rendered in at least 42 different ways, some of which are evidently abbreviated forms. The following sample indicates the range of variation: Cacxa1, Coetzal, Guericochal, Huequetzal, Huisacal, Quechal and Quetzal. At San Francisco Solano two individuals were identified in 1706-1707, when the mission was at San IIdefonso. These were listed as "Quesal" and "Quizal," one an adult male, the other an adult female, and both are said to have formerly been at Mission Santa Rosa de Nadadores of the Monclova area. The female was married to a "Tepeguan" (Solano Registers).

Between 1674 and 1708 the Gueiquesal were most frequently reported as ranging over northeastern Coahuila east of the mountain front and also northward across the Rio Grande as far as the southern margin of the Edwards Plateau (Alessio Robles 1938:279-280,536; Bolton 1916:285,299,301-308; Figueroa Torres 1963:58-69,89,103-119; Griffen 1969:33,35,38,53,87-90,103,117,126,132,155-168; Steck 1932:6-7,9-13,19-21,24-26). An account of 1708, however, reported "Cacxales" in northern Nuevo León east of present Lampazos (Maas 1915:23). The maps of Jiménez Moreno (1944) and Swadesh (1959) show the earlier range of the Gueiquesal accurately, but the maps of Driver and Massey (1957) and Ruecking (1955a:"Kesale") place them too far west in Coahuila.

Gueiquesal also entered other missions in Coahuila. "Cotzales" and "Quechales" were present at Santa Rosa de Nadadores when it was founded in 1677 (Bolton 1916:287; Orozco y Berra 1864:302), and this is confirmed by the San Francisco Solano records noted above. "Coetzales" were at El Dulce Nombre de Jesús de Peyotes when it was founded in 1698 near present Villa Unión (Morff 1856:433434; Portillo 1886:187). Some also entered San Miguel de Aguayo of Monclova, 26 individuals being reported there as late as 1762 (Portillo 1886:251).

Demographic and cultural information on the Gueiquesal may be found in the various sources cited above. At one of the early, temporary missions in northeastern Coahuila a total of 512 "Guyquechales" was said to be present in 1674, and shortly afterward Spaniards observed a war party of 98 Gueiquesal males at a locality north of the Rio Grande. It is said that the Gueiquesal, like all of their associates in the area, did not practice horticulture. Foods included various unspecified roots, root crowns of the maguey plant, fish, and deer and. bison flesh. In common with other Indian groups of the same area, the Gue- iquesal sometimes killed bison north of the Rio Grande and carried dried meat back to encampments south of the river.

Warriors in the party of 98 mentioned above were described in missionary reports. Each man wore a breechcloth of deerskin and a headdress that is confusingly described but seems to have consisted of an encircling band of reed or cane to which were attached mesquite and other leaves as well as multi-colored feathers. The warrior's face and body were painted, the designated colors being red, yellow and white (derived from ochre and clays). The painted face was said to resemble a mask, but the arms, shoulders and chest had designs formed by lines 
or stripes. Each man carried a bow, arrows and a leather-covered shield. Entry into battle began with "yelling." In the described battle seven or eight enemy warriors were killed and four women and three children taken captive before the enemy fled. One document mentions an adopted Spanish boy captive which the Gueiquesal said had been obtained from "Cabezas." The boy"s face and body were marked, probably by tattooing, but it is uncertain whether the designs should be attributed to the Cabezas or to the Gueiquesal. According to Bolton's translation (1916:301), there was "a black streak on his face running from the forehead to the nose, and two on the cheeks, one on each, like $0^{k} \mathrm{~s}$, and many rows of them on the left arm and one on the right."

A "ball game" (five men on each team) was once played--Gueiquesal against Tobosos--for custody of a Spanish missionary. The Gueiquesal were friendly to Spaniards and wanted to keep the missionary-alive; the Tobosos wanted his "head" for use in a ceremony. The Gueiquesal lost the game but did not keep their word. They fought the Tobosos, who outnumbered them, and won. In another document mention is made of the Gueiquesal performing a "dance" in honor of a missionary.

Hodge (1907,I:511,512; 1910, II:339) has given separate group status to "Gueiquesales," "Guisoles," and "Quesa1," but these are now considered to be variants which refer to a single ethnic unit.

Guerjuadan. In 1707, when San Francisco Solano was located at San Ildefonso, one Guerjuadan, a five-year-old girl, was baptized (Solano Registers). Two similar names, Guergaida and Guerjuatida, were recorded for one individual, an adult female, at Mission Sàn Antonio de Valero of San Antonio, Texas (Valero Registers, entries of 1721 and 1727). This individual was said to have come from "Rancheria Grande," which refers to an aggregation of refugee groups, many of them from northeastern Coahuila, located northeast of San Antonio between the Colorado and Brazos Rivers (Hodge 1910, II:354). A11 three names may refer. to the same ethnic unit. Circumstantial evidence suggests that the Guerjuadan once 1 ived west or northwest of Guerrero.

Hape. The Hape have been recorded under at least 23 similar names, among which are Aba, Ape, Gaapa, Heape, Iape, Jeape, Xape, Xapoz and Xiapez. Documentary evidence seems to indicate that the Hape originally 1 ived near the Jumano in west-central Texas, particularly in the San Angelo area, until both groups were displaced southeastward by Apaches.

Missionaries from New Mexico worked among the Jumano of west-central Texas in 1629 and reported that the "Iape" (also recorded as "Jape" and "Xapi") were neighbors of the Jumano (Ayer 1916:63,165,278; Forrestal 1954:62-63,165; Hodge, Hammond and Rey 1945:95-96,164,195,318-319). In 1675 Bosque (Bolton 1916:296) encountered "Jeapa" some 10 or 12 miles north of the Rio Grande, apparently not far from present Eagle Pass, Texas. They were then living south of the Rio Grande but had crossed the river to hunt bison. In 1684 Dominguez de Mendoza 
(Bot ton 1916:339-340), who was guided by Jumano, met or heard of "Abas" in the western part of the Edwards Plateau. In the years 1689, 1690 and 1691 "Apes;" "Apis," and "Hapes" were reported at various localities both north and south of the Rio Grande in the Guerrero-Eagle Pass sector, usually associated with groups that included the Jumano (Botton 1916:356; Gơmez Canedo 1968:8-9,91,134, 160; Weddle 1973:177). In one encampment that included Hape, Jumano and Mescal; not very far south of Guerrero, Spaniards in 1689 observed a tall pole to which were attached 16 heads of slain enemies.

In 1699, when Mission San Juan Bautista was first established on the Rio Sabinas of northeastern Coahuila, some Hape were present (Ríos 1959:106), and some of these appear to have gone with the mission when it was moved northward to Guerrero in 1701 (Maas 1915:30). Thereafter no Hape were recorded at this mission. One "Jape" female was identified at Mission San Francisco Solano in 1705 when it was still at Guerrero. This woman was married to an "Xarame" (Solano Registers). In 1727 Rivera y Villalon (1945:126) noted the presence of a few "Apes" at Mission San Bernardino de-la Candela near modern Candela in eastern Coahuila. After this no more is heard of the Hape.

Hume. The Hume are known by some 11 similar names, among them Jume, Jumi, June, Lume, Xomi, Xume and Yume, some representing errors made in transcription. Espinosa (Maas 1915:30) stated that some "Jume" were at Mission San Juan Bautista prior to 1708, but the censuses of 1734 and 1772 do not identify any group with a similar name. One "Xume" (adult female) was recorded at San Francisco Solano in 1708, when this mission was at San Ildefonso (Solano Registers). The premission territory of the Hume was mainly north to northwest of Guerrero, between the Rio Grande and the southern margin of the Edwards Plateau of Texas, where they were variously recorded as "Humez," "Jume," and "Jumee" in records of 1675 and 1684 (Bolton 1916:298,308,339-340). Their range probably al so extended southward across the Rio Grande. Some Hume were included in delegations which visited the Spaniards of Monclova in 1675 (Portillo 1886:81,96). At Teast two Hume can be identified in the registers of Mission San Antonio de Valero of San Antonio, Texas, where in 1719 they were listed as "Jume" and "Jumi" (Valero Registers).

The documents contain a few details on Hume warfare: some women were seen carrying bows and arrows; children were taken captive, presumably for adoption; and there is mention of cannibalism connected with warfare.

Jacao. This name, along with several obvious variants, is known only from the two censuses taken at Mission San Bernardo. In the census of 1734 (Garza Falcón. 1734a:20,23) five Jacao are listed under the names "Jacajo" and "Xacajo." Two families are involved, and the identified Jacao include two adult males, one with two children, the other with one child (sex of children not specified). The wives of the two men are not ethnically identified. In the census of 1772 (Rodriguez 1772a:65-66,68) eight Jacao are identified as either "Jacao" or "Jaco." These eight individuals are associated with six families, and the Jacao reported consist of two adult males, four adult females, and two children, one male, the other female. Spouses are identified as "Chaguan" (Siaguan), "Pacó" (Pacoa), "Paquachi" (Pacuache), and "Paxac" (Paac).

The name Jacao and its variants (Jacajo, Jaco and Xacajo) are all known from the year 1734 or later. They probably refer to an ethnic unit recorded in earlier documents (1670-1703) by such plural forms as Acafs or Acafes, Cacages, Cacajes, 
Decafes, Garafes, Jacafes, Xacafes and Xacajes. This unit can be linked with an area that includes extreme northeastern Coahuila and the adjoining part of northern Nuevo León (Alessio Robles 1938:232,238,351-352,371, 385-386; Cuervo y Valdếs 1700:11,16; González 1887:268; Griffen 1969:159; Portîl10 1886:64,205). In 1693 Salinas Varona (Gómez Canedo 1968:306) encountered "Cacages" on the Rio Grande in the same locality where the Guerrero missions were established a few years later.

An early published suggestion (Hodge 1907,I:731) that the "Acafes and Cacafes" of Spanish writers may be identified with the Kuasse and Akasquy reported by chroniclers of the La Salle expedition (1685-1687) should be disregarded.

Jfcaragrande. Three adult females, identified as "Jicaragrande" and "Hicaragrande," were recorded at San Francisco Solano in 1706-1707, when the mission was at San Ildefonso (Solano Registers). The name is Spanish and is probably best translated as "large gourd cup." One of the women is identified by a native personal name, Macacura, and she is said to have been married to a "Ticmamar" (Tumamar) who at the time was serving as leader (capitan) of the Terocodame. Another woman was married to a Terocodame. The name Jicaragrande has not been found in other Spanish documents, but the recorded associations with Terocodame suggest that the Jfcaragrande may have originally lived on both sides of the Rio Grande northwest of Guerrero.

Juanca. Two Juanca individuals were recorded at Mission San Bernardo, one adult male in the census of 1734 (Garza Falcón 1734a:22) and one adult female in the census of 1772 (Rodriguez 1772a:70). A few Juanca were also recorded in the registers of Mission San Antonio de Valero at San Antonio, Texas, under a variety of names similar to Juanca (Valero Registers). Information on the Juanca has recently been summarized by Campbell (1977). The Juanca pre-mission range seems to have centered around present Frio County, Texas, southwest of San Antonio.

Julime. Two adult Julime females were recorded in the baptismal register of San Francisco Solano in the years 1706-1707, when the mission was at San Ildefonso (Solano Registers). One entry in the register identifies the person as "Julimes o Juribes." Spouses are not ethnically identified. In 1708 Espinosa (Maas 1915:35) mentioned that Julime were present at San Francisco Solano.

The Julime, sometimes also referred to as Julimeño, were not native to northeastern Coahuila. They were refugees from much farther west, particularly along the Rio Conchos of present northeastern Chihuahua (Forbes 1959,1960; Hackett 1926, II; Kelley 1952-1953; Sauer 1934). Although poorly documented, a considerable number of Julime seem to have moved into northeastern Coahuila in the middle eighteenth century. For a time they lived in a "pueblo" at or near Mission San Francisco Vizarrón, which was established at present Vill la Unión, Coahuila, in 1737 (Bolton 1913:89; Kinnaird 1958:150-151,188; Morfi 1856:435-436; Revi11a Gigedo 1966:61; Weddle 1968:299-300,306,330,333-334). In Coahuila these Julime were friendly with the Mescalero and other Apache and may have been absorbed by these Apaches in the latter part of the eighteenth century. It is generally believed that the Julime spoke a Uto-Aztecan language, although no sample of the language appears to have survived. 
Santos (1966-1967:138) has claimed that a few Julime were at Mission San Antonio de Valero of San Antonio, Texas, but this is in error. He evidently confused the records of San Antonio de Valero with those of San Francisco Solano, which are housed together in the San Fernando Archives of San Antonio.

Jumano. Documents pertaining to the Jumano of western Texas and northern Chihuahua have been intermittently studied over a period of some 75 years and considerable information has been presented in publications by Bolton $(1911,1912)$, Forbes (1957, 1959, 1960), Hodge (1910), Kelley (1955), Sauer (1934) and Scholes and Mera (1940). These indicate that the problem of Jumano identity is complex and that the documentary evidence can be interpreted in various and sometimes contradictory ways. The concern here is with evidence of Jumano presence at the Guerrero missions and in the surrounding area near the end of the seventeenth century, prior to the time when the name Jumano was also used to refer to certain Wichita groups of the Red River region.

In earlier documents the name Jumano appears in a least 30 recognizable forms, including Auman, Chaumen, Chomen, Chouman, Humana, Iumana, Jaman, Lumano, Shuman, Tuman, Umano, Xoman, Xumana and Jumana. In northern Chihuahua the Jumano were a]so known to Spaniards by several variants of the name Patarabueye.

A point of special interest is that as early as 1684 there is good evidence of Apache displacement of Jumano from the southern Plains and western Edwards Plateau regions of Texas, particularly in the report of Dominguez de Mendoza's expedition from the El Paso area eastward into the Edwards Plateau (Bolton 1916: 313-343). After this the Jumano were repeatediy encountered by Frenchmen connected with the La Salle expedition of 1685-1687 and by Spaniards connected with successive attempts to occupy Texas and thereby halt further French intrusion. In the documents published by Gómez Canedo (1968:index) Jumano are repeatedly reported in the area lying between the Rio Sabinas of northeastern Coahuila and the Guadulupe River northeast of San Antonio, Texas. Remnants of these same Jumano were recorded at Guerrero missions.

At least 16 individuals were identified as "Juman" in the baptismal register of Mission San Francisco Solano during the period 1706-1708, when the mission was at San Ildefonso (Solano Registers). Included are 4 aduit males, 6 adult females, and 6 children ( 2 male, 4 female, ages 2 to 10 years). Two personal names of children may be of Indian origin: Mueracuba (female) and Yquia (male). Spouses ace identified as "Babor" and other "Juman." Santos (1966-1967:158) has reported "Juman" at Mission San Antonio de Valero at San Antonio, Texas, but this is the result of confusing the registers of Valero with those of Solano.

Evidently Jumano never entered the missions of northeastern Mexico and southern Texas in any numbers. In 1708 Espinosa (Maas 1915:33) mentioned that "Yomines" were then present at Mission San Juan Bautista, but the censuses of 1734 and 1772 do not record any Jumano. Other Jumano who survived into the eighteenth century may have joined relatives along the lower Rio Conchos of northern Chihuahua or have been absorbed by their former Apache enemies.

Macapao. One adult female Macapao is recorded in the San Francisco Solano baptismal register for the year 1706, when the mission was at San Ildefonso (Solano Registers). Her husband is listed as a "Siaban" (Siaguan). This is the only known record of 
the Macapao. Ruecking (1955a:312) has equated Macapao with Macapaqui, the name of a group reported in the vicinity of Monterrey, central Nuevo León, prior to 1650 (León y otros 1961:189). This linkage, which is evidently based only on similarity in the names, has yet to be demonstrated. Since so many western and so few eastern groups came to San Francisco Solano when it was at San IIdefonso, the Macapao probably lived somewhere west of the Guerrero mission center.

Macocoma. An aduit female Macocoma was present at San Francisco Solano in 1706, when the mission was located at San Ildefonso (Solano Registers). It has sometimes been assumed that Macocoma and Cocoma are synonymous names (Hodge 1910,II: 426; Ruecking 1955a:261,302,312,313), which appears reasonable on the bas is of such information as is available. In 1741 two individuals, one a Macocoma (also rendered as Mecocoma) and the other a Cocoma, were recorded at Mission San Antonio de Valero at San Antonio (Valero Registers). The Cocoma seem to be recorded under several similar names (Cocomaque, Cocomate and Cocuma) for a large area that extends from the Rio Conchos of Chihuahua eastward to the northern side of the Rio Grande not far from Guerrero (Bolton 1916:299; Griffen 1969:88,158; Hackett 1926,II:395 and 1931, I:138-139; Porti11o 1886:78; Revi11a Gigedo 1966:60).

Malaguita. This name has been rendered in at least 25 different ways, including Maguyalita, Malagueco, Malaguito, Malaquit, Maraguita, Marahuiayo, Maraquita and Marhita. So far as the Guerrero missions are concerned, the Malaguita were a late increment from the east. During the eighteenth century they were recorded at various localities along the Gulf coast, extending from the Nueces River of Texas southward across the Rio Grande into northern Tamaulipas (Benson 1950:30; Bolton 1915:97,104-106; Cabello 1780a:37-38 and 1780b:78-79; De Villiers du Terrage et Rivet 1919:415; Saldivar 1943:map). During this period Padre Island (lower Texas coast) was sometimes referred to as La Isla de los Malaguitos.

The Malaguita were represented at two Guerrero missions, San Bernardo and San Juan Bautista, for which they were recorded only in the census of 1772 (Rodriguez 1772a:67,69 and 1772b:124-126,128-129). At San Bernardo there were two

"Malaguite," one an adult male married to a "Paco" (Pacoa), the other a male child, an orphan. At San Juan Bautista were 10 "Maraquite": 5 adult males, 4 adult females and 1 male child. Spouses were identified as other "Maraquite," "Mescal," "Patacalo" and "Passtacalo" (Patacal).

Malaguita entered other missions east of Guerrero. At San Antonio, Texas, Malaguita were represented at three missions, all established after 1731: Nuestra Señora de la Purisima Concepción de Acuña, San Francisco de la Espada, and San Juan Capistrano (Cabel 10 1780a:37 and 1780b:77-78; Dabbs 1940:9; Dolores 1762a: 52; Habig 1968:175,218; Santos 1966-1967:157). At Mission Refugio of present Refugio, Texás, Malaguita were still being recorded as late as 1819 (Bolton 1913: 447; Oberste 1942:271,398). On the south bank of the Rio Grande in northern Tamaulipas, remnants of the Malaguita entered two missions after .1750 : San Agustín de Laredo at Camargo and Señor San Joachín del Monte at Reynosa (Bolton 1913:450-451; Castañeda 1938, III:159; Troike 1962:Table 1); and in eastern Nuevo León the Malaguita were also present in at least two missions (Kinnaird 1958: 195). It is evident that the massive colonization of Tamaulipas in the middle eighteenth century led to extensive displacement of the Malaguita. 
Mamuqui. The name Mamuqui occurs once in the San.Francisco Solano baptismal register. This is for the year 1706, when the mission was at San I7defonso (Solano Registers). Although it has been accepted as an ethnic group name (Hodge 1910,II:733; Swanton 1940:134), the context in which it appears in the Solano register suggests that it is probably the native personal name of an adult female. This conclusion receives some support from the fact that in documents of the surrounding areas no ethnic group name has been found which closely resembles Mamuqui.

Manico. The Manico, also known by several similar name variants (Manicu, Minicau and Minicu), were first recorded in 1690 by Mazanet, who encountered them on what is now the Frio River, apparently in or near present-day Frio County, Texas (Gómez Canedo 1968:160). In 1704 at least one "Minicau" individual, a.female of undesignated age, was baptized at Mission San Francisco Solano when the mission was still at Guerrero (Solano Registers). In 1708 Espinosa 1isted the "Manicu" among Indian groups then Tiving north of the Rio Grande in a generalized easterly direction from the Guerrero mission center (Maas 1915:36-37). Some of the Manico thereafter entered Mission San Bernardo. In the census of 1734 five "Minicu" were identified: two adult males and their three children (Garza Falcon 1734a:21-22); and in the census of 1772 four "Minicu" were recorded: one adult male, two adult females, and one male child (Rodriguez 1772a: 68,71 ). Spouses are listed as other "Minicu," "Paco" (Pacoa), and "Paquachi" (Pacuache). After this the Manico disappear from the record.

In Hodge $(1910,1 \mathrm{I}: 256,1091)$ the name "Piniquu" is listed as a synonym of "Minicau," but this does not seem to be phonetically reasonable; furthermore, in 1704 "Minicu" and "Piniquu" individuals were distinguished in the baptismal records of Mission San Francisco Solano (see also Piniquu). Hodge (1907, I:795,800,845) also speculated that the Manico may have been the same people as the "Maliacón" encountered by Nuñez Cabeza de Vaca in 1535 and also the same as the "Meracoumen" recorded in 1687 by Henri Joutel, chronicler of the La Salle expedition to Texas. This speculation is based on presumed similarities in the names, two of which are recorded in Spanish, the third in French. Some plausibility is attached to the Maliacôn-Manico linkage, since Krieger (1961) has presented evidence which supports placement of the Maliacón inland on the South Texas Plain somewhere south of the lower Nueces River, possibly in the area of present Duval and Jim Wells Counties, which could be within the greater territorial range of the Manico as known some 150 years later. The Meracoumen-Manico 1 inkage seems farfetched, since Joutel (Stiles 1906:126) makes it clear that the Meracoumen were encountered while a French party was traveling northeastward from Matagorda Bay to the present Colorado River. The probability is low that the Meracoumen of 1687 would have moved, only three years later, some 175 miles westward to become Mazanet's Manico of 1690.

Manos Prietas. This name is Spanish ("dark hands"), and no native name for this group has ever been identified. The Manos Prietas were most frequently reported as living in northeastern Coahuila along and east of the mountain front but not ranging as far east as Guerrero (Griffen 1969:88-89,160,162). It is clear that at times they ranged north of the Rio Grande in modern Texas, particularly to hunt bison (Steck 1932:14-15,21). An even wider range is suggested by the Marin report of 1693 (Hackett 1926, II: 395 ), which noted Manos. Prietas on the lower Rio
Conchos of northeastern Chihuahua. 
In 1706, when San Francisco Solano was located at San Ildefonso, one adult female, married to a "Terocodame," was identified as Manos Prietas. The register entry states that this woman had previously been baptized at Mission Santa Rosa de Nadadores (Solano Registers). The Manos Prietas apparently never entered the missions of San Juan Bautista and San Bernardo, and they were not reported at other missions farther east. Hodge (1910, II:426) indicated that some Manos Prietas were at Mission San Antonio de Valero of San Antonio, Texas, but this represents confusion of the Valero records with those of San Francisco Solano. In 1674 some Manos Prietas gathered at the early but temporary mission of San I7defonso de la Paz, located between the Río Sabinas and the Rio Grande, possibly near present-day Zaragoza, Coahuila (Figueroa Torres 1963:77,115). Some were also at Santa Rosa de Nadadores, north of Monclova, as early as 1675 (Alessio Robles 1938:269,279; Figueroa Torres 1963:67). Manos Prietas were a] so recorded (1698-1701) for missions of the Parras area of southern Coahuila (Griffen 1969:162,172-174). Sti11 others entered Mission San Miguel de Aguayo at Monclova, where 25 individuals were reported still in residence as late as 1762 (Porti110 1886:251).

One account of 1675 reported the Manos Prietas as numbering 232 individuals (Alessio Robles 1938:242-243). Recorded cultural details include absence of horticulture, eating of unspecified wild roots and fruits, fishing, hunting deer and bison with bow and arrow, joint dances with other groups, and formal exchange of bows and arrows to symbolize peaceful. relations (Bolton 1916:306; Figueroa Torres 1963:67,104; Steck 1932:14-15).

Matuimi. Two Matuimi individuals are identified in the baptismal register of San Francisco Solano for the year 1708, when the mission was at San Ildefonso. One is an adult male, the other his one-year-old son. The man's wife is listed as a "Terocodame" (Solano Registers). As the name Matuimi has not been found in other Spanish documents, its recording at San Francisco Solano with the names of so many groups of western origin suggests that the Matuimi may have originally lived west and northwest of the Guerrero mission center.

Maubedan. Two Maubedan individuals, a father and his four-year-old son, are identified in the baptismal register of San Francisco Solano in 1706, when this mission was at San Ildefonso. The man's wife is listed as a "Terocodame"

(Solano Registers). Ruecking (1954a:17; 1955a:315) has erroneous7y rendered this name as "Manbedan." Maubedan as a group name has not been found in other Spanish documents. Such information as is available suggests that the premission territorial range of the Maubedan was probably west and northwest of Guerrero.

Maurb. In the 1734 census taken at Mission San Juan Buatista, one adult male is identified as "Miguel Maurb" (Garza Falcón 1734b:15). "Maurb" here may be merely part of the personal name, or it may be an ethnic group name which through oversight was not set off by punctuation. Since neither Maurb nor any similar name has been found in other documents, it appears more reasonable, at least for the present, to interpret Maurb as part of the personal name, probably of native origin. 
Mauyga (or Manyga). In the baptismal register of San Francisco Solano for the years 1706-1707, when this mission was at San IIdefonso, 10 individuals (4 famiTies) are recorded as either Mauyga or Manyga ( $u$ and $n$, when handwritten, are often difficult to distinguish). Of these 10 individuals, 2 are adult males, 2 are adult females, and 6 are children, 4 male, 2 female, whose ages range from 1 to 9. Spouses are identified as "Gabilan," other "Mauyga, "Tepehuana" (Tepehuan), and "Terocodame." The second name of one male child (his mother was a Tepehuan) appears to be of Indian origin: Andrés Pabotasona (Solano Registers).

The names Mauyga and Mauiga are entrenched in the 1iterature (Hodge 1920, II:733; Ruecking 1954a:18 and 1955a:320; Swanton 1940:134), but it now appears that the missionaries at San Francisco Solano were actually recording the names as Manyga. Griffen $(1969: 76-77,171)$ has found a series of group names similar to Manyga in Parras records (southern Coahuila) for the period 1605-1635. These names include Managua, Manague, Managui, Manahua, Manahue, Manaue and Manave. Griffen considers these to be variants of the same name and suggests that the ethnic group involved may have been a subdivision of the Guachichil of Zacatecas and parts of certain closely adjoining states (Durango, Coahuila, Nuevo León and San Luis Potosi). It may be noted that one Guachichil individual was present at San Francisco Solano, and 12 Guachichil were also recorded at Mission San Bernardo in 1772 .

Mescal. Mescal is an Hispanicized Nahuatl word that originally referred to various species of the maguey plant. In Spanish documents that pertain to the area surrounding Guerrero the Indians known as Mescal were consistently distinguished from all other ethnic groups with native names. The name has been rendered in at least 18 different ways, including Mefcal, Mescata, Messcal, Mexcal, Mezcal, Miscal, Mixcal and Mizcale. These Mescal Indians are not to be confused with the Mescalero Apache, who appeared in the area after the Mescal were were well known (Schroeder 1960, III:12-13).

The pre-mission territorial range of the Mescal is fairly well documented. It extended from the Rio Sabinas in northeastern Coahuila north-northeastward to the Guerrero sector of the Rio Grande, and then northeastward to the vicinity of San Antonio, Texas. The Mescal were most frequently seen near three rivers which cross this territory, the Rio Grande, the Nueces and the Frio. The most informative sources on territorial range are Bolton (1916:354-358,389-390,406), Gómez Canedo (1968:xi ii , 8-9,72,75, 88, 90-91, 134,160,173, 232, 280, 289, 305-306, 356) and Weddle (1973:132-147,174-178). After missions were established at Guerrero, some of the unmissionized Mescal migrated farther northeastward to an area near the junction of the Little and Brazos Rivers in east-central Texas and were part of an aggregation of refugees and local groups known to Spaniards as Ranchería Grande (Hodge 1910, II:554; Tous 1930a:14,16-17).

The Mescal were well represented at San Juan Bautista at its two locations. Some were present when the mission was first established on the Rio Sabinas in 1699 (San Buenaventura y Salazar 1699:45), and when the mission was moved to the Guerrero area in 1701, some of the Mescal followed. In 1727 Sevillano de Paredes (1727:42) reported the Mescal as still present, and in the census of 1734 (Garza Falcón 1734b:15) 17 "Mescale" individuals are identified: 6 adult males and their 11 children. Spouses are not ethnically identified. A document of 1738, cited by Porti110 (1886:283), records 81 Mescal at San Juan Bautista, 
but the census of 1772 (Rodriguez 1772b:123-128) indicates only 27 Mescal individuals: 12 adult males, 5 adult females and 10 children, 6 male, 4 female. Spouses identified include "Cachsaputal" (Cachopostal), "Maraquito" (Malaguita), "Pacoa," "Panpopa" (Pampopa), "Passtalaco" (Pastaloca), "Patacal" and "Sixama" (Sijame).

Five Mescal are identified in the baptismal register of San Francisco Solano for the year 1706, when this mission was at San Ildefonso. These include an adult male and his four children, two male and two female, ages one to eight years. The second names of two boys are probably of native origin, Comaranaucos and Terocupan (Solano Registers).

Some Mescal were recorded at Parras in southern Coahuila, 1719-1721 (Griffen 1969:163,173-174). A few Mescal were also present at San Antonio de Valero of San Antonio, Texas, but only one individual is identified (1728) in the records (Valero Registers). This person probably came from Rancheria Grande. Most of the Mescal who ehose to enter missions went to San Juan Bautista.

From various records cited above a few details on Mescal culture may be gleaned: encampments usually shared with other groups; absence of horticulture; frequent shifting of settlements in order to obtain foodstuffs; seasonal gathering of wild plant foods, including fruit of the prickly pear; bison hunting with bow and arrow; grass-covered houses (possibly round in floor plan, since it is stated that the houses resembled haystacks); tattooing; and heads of recently slain enemies attached to a tall pole. To these may be added other details connected with Spanish capture of a Frenchman who had become a revered leader of the Mescal and their close associates. European influence is obvious. The list of recorded traits includes: Targe structure for the French leader, apparently consisting of a wooden framework (form undescribed) covered with bison hides; inside the structure was a platform for the leader, with chairs, cushions and rugs, all involving use of bison hides; interior of structure said to be "decorated"; honor guard (42 warriors); attendants removed perspiration from leader"s body, fanned him with feathers, and burned incense consisting of animal fat and other unspecified substances.

The language spoken by the Mescal has been identified as Coahuilteco by Garcia (1760:title page), and this receives support from Mazanet's early statement about the prevailing language spoken in the area ranged by the Mescal (Gómez Canedo 1968:240).

Mesquite. Some confusion is connected with Mesquite as an ethnic group name. Mesquite was used by Spaniards in referring to several apparently unrelated Indian groups in three areas: northeastern Chihuahua, southern Texas and central Tamaulipas. The Mesquite recorded at Guerrero missions were probably the Mesquite of southern Texas, for which Ruecking (1955a:323) has coined a special name, Mesquitexa.

In a document of 1670 (Griffen 1969:156), the name "Biay" is listed among the troublesome Indian groups living somewhere considerably to the north of Monterrey. In 1708, while working at one of the Guerrero missions, Espinosa (Maas 1915:36-37) reported "Bioy o Mesquites" as living an unspecified distance east of Guerrero, 
meaning somewhere in southern Texas. This seems to identify "Bioy" as the native name of a group also known as Mesquite. The two names, "Biay" and "Bioy," may refer to the people who were recorded in 1754 as "Viayan" and "Biayan" and said to be a subdivision of the Pamaque (Guadalupe 1754:179). The Pamaque can be linked with an area near the Gulf Coast between the San Antonio and Nueces Rivers.

In 1716, when San Francisco Solano was located at San José, about eight miles up the Rio Grande from Guerrero, two adults, one male, the other female, were identified as Mesquite (Solano Registers). The male, however, was also identified as "Mesquite o Lagaun." If "Lagaun" here is a native name for the Mesquite, it would appear that the Mesquite at San Francisco Solano were not the same as the Mesquite-Bioy of Espinosa, and this suggests that these Solano Mesquite may have come from northeastern Chihuahua (see Hackett 1926, II:395; Reindorp 1938: $12,26)$. This evidence is tenuous and should be approached with caution.

The Mesquite of southern Texas entered several missions at San Antonio: San Antonio de Valero (the Valero registers identify 28 Mesquite individuals between the years 1720 and 1761), San Francisco de la Espada, and San José y San Miguel de Aguayo (Habig 1968:214; Kress and Hatcher 1931:51; Sandoval 1733: 165,168-169). Apparently the Mesquite of southern Texas were the same as the Mesquite reported (1716) in the refugee encampment known as Rancheria Grande, located near the junction of the Little and Brazos Rivers in east-central Texas (Tous 1930a:8,16).

The Mesquite of central Tamaulipas (Saldivar 1943:30) appear not to have been displaced very far northward from the area where they were first reported.

Muruame. Three "Muruame" are listed in the baptismal register of San Francisco Solano in 1707, when the mission was at San Ildefonso. These represent a single family: man, wife, and male infant (Solano Registers). In 1708 Espinosa (Maas 1915:36-37) stated that the "Moroamo" lived at an unspecified distance eastward from the Guerrero missions and north of the Rio Grande. The Muruame were later well represented at Mission San Antonio de Valero of San Antonio, Texas, in whose registers at least 42 Muruame individuals can be identified between the years 1721 and 1775, the group name being variously rendered as Mariame, Marueana, Merguan, Merhuam, Moroame and Moruane (Valero Registers).

The pre-mission territorial range of the Muruame is consistently reported to have been along and between the Colorado and Guadalupe Rivers east and southeast of San Antonio (Gómez Canedo 1968:161,244,300,306). They have often been equated with the "Mariames" of Nuñez Cabeza de Vaca, a group which seems to have been associated with the lower Guadalupe River in the early sixteenth century. This equation is plausible, although some 170 years separate the two bodies of information.

Hodge (1907, I:943) recognized "Morbanas" as the name of a separate ethnic group, but comparison of documents clearly shows that Morbana is a variant of the name Muruame. The equation of Meracouman and Menenquen with Muruame should be disregarded (Hodge 1907,I:845 and 1910,II:1089). As no sample of Muruame speech seems to have been recorded, Swanton's $(1940: 136)$ speculation that the Muruame language 
"may have been Coahuiltecan or Tonkawan" cannot be tested. It could just as well have been some other language that has not been recorded.

Ocana. The Ocana are known by several similar names, including Acani, Cane, Ocam, 0can and Ocano. They seem to have been first recorded in 1670 as one of many Indian groups from the north that occasionally raided farm and ranch settlements in the vicinities of Monterrey and Saltillo (Bolton 1916:284; Griffen 1969:163). Fray Manual de la Cruz, during missionary work north of the Rio Grande in 1674, recorded "Ocanes" at a locality about eight miles north of that river, possibly in present Maverick County, Texas (Figueroa Torres 1963: 105). The next year, 1675, the Bosque-Larios expedition heard of "Ocane" in the same area (Bolton 1916:296-297,308). Domínguez de Mendoza also met or heard of "Acanis" in 1684, when he was in the western part of the Edwards Plateau in Texas (Bolton 1916:339). In 1691 and again in 1693 Mazanet encountered "Ocan" and "Ocanas" on both sides of the Rio Grande in the Guerrero sector (Gómez Canedo 1968:235,280; Hatcher 1932:52). Most of the pre-mission records thus place the Ocana along the Rio Grande in the Eagle Pass-Guerrero area.

In 1700, when Mission San Felipe de Valladares was established near present Candela, eastern Coahuila, the "Ocanes" were named as one of five groups present (Cuervo y Valdés $1700: 11$ ). At least one Ocana female was at Mission San Francisco Solano in 1706, when it was at its San Ildefonso location (Solano Registers). Three of her children were baptized on the same day, and it is recorded that the father of her children was a "Zenizo" (Cenizo).

Documents of a later time which refer back to the foundation of Mission San Bernardo in 1703 agree that the Ocana were present when the mission was formally established (Espinosa:1964:756; Morfi 1935b:321; Ximenes 1762a:112-113 and 1762b: 108-109).. In 1708 Espinosa (Maas 1915:33) referred to the Ocana as one of the groups well represented at San Bernardo. In the census of 1734 taken at Mission San Bernardo, nine individuals are identified as "0cam": three adult males and their six chilldren (Garza Falcón 1734a:21-22). Six "Ocan" and "Ocam" were still there in 1772, the census for that year (Rodríguez 1772a:66-68) indicating the presence of six persons: three adult males, two adult females, and one male child. Spouses are listed as "Catujan," "Pachal" and "Paquachi" (Pacuache). A few Ocana also found their way to Mission San Antonio de Valero at San Antonio, Texas. Two adult females died there in 1728, and one of these was married to a "Siaguan" (Valero Registers). Mazanet's observations on languages spoken in southern Texas suggest that the Ocana spoke Coahuilteco (Gómez Canedo 1968:240).

Ochayal. See Achoj.

Ocora. In the San Bernardo census of 1734 (Garza Falcón 1734a:20) four "Ocora" are Tisted, an adult male and his three children. Apparently the name refers to the same ethnic group recorded as "Cora" in 1674, who were named on a list of 17 Indian groups said to be represented at a temporary mission known as San Ildefonso de la Paz (Figueroa Torres 1963:77). This mission was in northeastern Coahuila between the Rio Sabinas and the Rio Grande west or northwest of. Guerrero, possibiy near modern Zaragoza, Coahuila. In 1708 Espinosa (Maas 1915: 
36-37) referred to "Cocore" in a list of groups at that time said to be living across the Rio Grande north of the Guerrero missions. If the names Ocora, Cora and Cocore are accepted as synonymous, the original 0cora range must have extended from the Rio Sabinas northward across the Rio Grande, perhaps as far as the southern margin of the Edwards Plateau. Hodge $(1907,1910)$ does not have entries for any of these names. According to sources cited by Figueroa Torres, the "Cora" and groups associated with them ate roots, acorns and bison meat.

Oydican. Seventeen "Oydica" and "Oydican" can be identified in the baptismal register of San Francisco Solano for the years 1706-1707, when the mission was at San Ildefonso (Solano Registers). Of these, seven are adult males, two are adult females, and eight are children, four male, four female, whose ages range from two months to nine years. Bolton (Hodge 1910,II:180) has stated that the Oydican intermarried with the Terocodame at this mission, but no spouses are ethnically identified in the baptismal register. The second names of two children are probably of Indian origin: Simón Cupiol and Clara Hayuni.

Oydican may be a shortened form of the name Doaquioydacam, which occurs on a list of 24 groups said to have submitted to Spanish authority in Coahuila by the year 1674 (Alessio Robles 1938:232). The pre-mission territorial range of the Oydican was probably somewhere northwest of Guerrero.. Santos (1966-1967: 158) has reported that four Oydican are recorded in the burial register of Mission San Antonio de Valero of San Antonio, Texas, but my inspection of the register failed to confirm this report.

Paac. The Paac appear to have been first recorded under the name "Pahaque" in a document of 1675 (Portillo 1886:175) which lists the names of 18 Indian groups that sent representatives to Monclova, Coahuila. These Indians, it is said, were interested in having missions established in the region northeast of Monclova. Eight additional names on this 1675 list are identifiable as those of Indian groups that later entered missions at Guerrero.

Massanet observed "Paac" sharing encampments with other Indian groups in 1690 and 1691 (Gómez Canedo 1968:160,235; Hatcher 1932:52). In 1690 the Paac were named as one of nine groups seen on the Nueces River in what is now central Zavala County, Texas. In 1691 they were named as one of six groups encamped on arroyo de Caramanchel, believed to be present Comanche Creek, also in Zavala County. Since the Indian encampment was said to be about eight miles from a locality bearing the name Guanapacti, recorded as meaning in Spanish arroyo de Dos Aguas, it seems plausible to locate the encampment eight miles above the junction of Comanche and Chaparrosa Creeks in southwestern Zavala County. Thus, as of 1690-1691, the Paac can be associated with the area between the Nueces River and the Rio Grande that lies northeast of Guerrero. In 1707 Diego Ramon (1707:57) encountered a temporary settlement of 21 "Pacque" in the same area but east of the Nueces River, apparently in the vicinity of present Big Wells in northeastern Dimmit County, Texas (Hester and Hill 1975:21).

The 1734 census taken at Mission San Bernardo (Garza Falcón 1734a:21) identifies three "Pajaca" (one man and his two children), and the 1772 census at the same mission (Rodríguez 1772a:68) identifies five "Paxac" and "Paxaguis": one adult male, three adult females, and one female child. Paac spouses are identified as 
"Jacao" and "Paquachi" (Pacuache). The Paac, so far is now known, were not recorded at other Spanish missions of southern Texas and northeastern Mexico. Mazanet's statements about languages spoken in southern Texas suggest that the Paac spoke Coahuil teco (Gómez Canedo 1968:240).

Pachal. At least 18 names, some of which represent various kinds of recording error, refer to the Pachal: Pacal, Pacgal, Pachale, Pachan, Pachat, Pachol, Pacuchal, Paischa1, Paschal, Pasteal, Patcal, Patchal, Patehal, Patzal, Patshal, Pauchal, Paxchal and Paszchal.

The Pachal were represented at Mission San Juan Bautista when it was established in 1699 at its first location on the Rio Sabinas north of Candela, eastern Coahuila (Esteves 1699:40; Weddle 1968:21-25), but when this mission was transferred northward to the Guerrero locality the Pachal apparently did not move with it. Instead they entered Mission San Bernardo in 1703 (Weddle 1968:53), where they formed one of its more numerous Indian groups. Sevillano de Paredes $(1727: 49)$ noted their presence at San Bernardo in 1727 . The censuses taken later indicate 21 Pachal in 1734 and 24 in 1772.

The 21 Pachal of the 1734 census (Garza Falcón 1734a:21-23) are variously recorded as "Pachal," "Pacuchal," "Paischa1" and "Pauchal." Included are 10 adult males and 11 children of unspecified ages and sexes. The wives of the adult males are not ethnically identified. The 24 Pachal identified in the census of 1772 (Rodríguez 1772a:65-70,72) are all recorded under one name, "Pachal," indicating name standardization by that late date. of these 24 persons, 9 are given as adult males, 4 as adult females and 11 as children, 5 male, 6 female. Spouses are identified as "Aguayan," "Canoa" (Canua), "Ocan" (Ocana), "Patacal," and "Pacó" (Pacoa). Two "Pachal," an adult male and his young daughter, are recorded in the baptismal register (1732) of Mission San Antonio de Valero at San Antonio, Texas. This male was married to a "Terocodame" (Valero Registers).

The recorded pre-mission territory of the Pachal extended from the Río Sabinas of northeastern Coahuila (vicinity of present Lago de Don Martín) northward to Guerrero and across the Rio Grande to the Nueces and Frio Rivers north and northeast of Guerrero (Gómez Canedo 1968:160,236; Maas 1915:36-37). Guerrero seems to have been fairly close to the center of the Pachal's known territorial range. One cultural detail has been recorded. When San Buenaventura y Salazar (1699:45) was working at San Juan Bautista at its initial location on the Río Sabinas, he noted that the Pachal and their associates gathered prickly-pear fruits from the surrounding area. The observations of Mazanet on languages spoken in southern Texas suggest that the Pachal spoke Coahuilteco (Gomez Canedo 1968:240).

In connection with the Pachal, several published errors need correction: Bolton (in Hodge 1910, II:208) identified "Pasteal" as the name of a separate and distinct ethnic group of the Coahuila-Texas area. This error has been perpetuated by Ruecking (1954a:19; 1955a:342-343), Swanton (1940:135; 1952:310) and Webb (1952,II:344). Pasteal is actually a misreading of Patcal, which is a variant of Pachal (compare Dr. Velasco 1958:318 and Gômez Canedo 1968:160); (2) in the synonymy section of Hodge (1910,II:1117), Pastia is erroneousiy equated with Pasteal (see above); (3) in Branda (1976:708), I mistakenly equated Pasteal with Patacal. The name Pasteal should be struck from the 
record as the name of a separate group and also as a synonym for Pastia and Patacal; (4) Bolton (in Hodge 1910, II:183) referred to Pachaloco as "evidently a division of Pachal," but this cannot be demonstrated.

Pachana. One adult male is identified by this group name in the census taken at Mission San Juan Bautista in 1734 (Garza Falcón 1734b:17). As no closely similar name has been found in other Spanish documents of the general area, the name may be a distortion of some better known name, possibly Pausane (2 "Paysano" individuals are recorded in the San Bernardo census of 1734).

Pacoa. García (1760:title page) listed "Pacaos" and "Pacoas" as names for separate groups of the San Antonio and Guerrero missions that spoke Coahuilteco dialects. Cyrus Thomas (in Hodge 1910, II:191-192) ignored this distinction and equated the two in his article entitled "Pakawa." Data from the 1734 and 1772 censuses of the Guerrero missions, which were not available to Thomas, make it very clear that the "Pacao" and "Pacoa" were indeed separate and distinct ethnic units. The "Pacao" were represented only at San Antonio missions (mainly San Francisco de la Espada, with a few at San Antonio de Valero and Nuestra Señora de la Purisima Concepción de Acuña), and the "Pacoa" were represented oniy at the Guerrero missions (San Bernardo and San Juan Bautista).

The Pacoa seem to have been first recorded in 1699, under the name "Pacco," in a report on the re-establishment of Mission El Dulce Nombre de Jesús de Peyotes in northeastern Coahuilà, near modern Villa Unión (Cuervo y Valdés 1699:230-234). The "Pacuq" encountered in 1707 by Diego Ramón in what is now Dimmit County, Texas (east of Guerrero) were probably Pacoa (Ramón 1707:68-69; Hester and Hill 1975:21), since in 1708 Espinosa listed "Paco" as one of the Indian groups then living north of the Rio Grande and east of the Guerrero missions (Maas 1915:36):

The most informative statements about Pacoa territorial range were made in 1727 by Sevillano de Paredes $(1727: 49,50,55)$. When he was inspecting the Guerrero missions, Sevillano de Paredes was told that there had been a recent "revolt" of the "Paco" and "Pantascoyas" (Pastancoyas). These two groups moved down the Rio Grande about 40 miles to a place called El Carrizo, which evidently was about midway between Guerrero and Laredo, or somewhere in the vicinity of modern Hidalgo, Coahuila. When Sevillano. de Paredes was inspecting Mission Nuestra Señora de los Dolores de la Punta, near present Lampazos, Nuevo Leon, he learned that the "Pacoa" were a numerous "nation" with a population over 300 and that they were then living about 78 miles north of the mission. This distance would place the Pacoa in the area of El Carrizo noted above. Thus the available data suggest that the pre-mission range of the Pacoa was east and southeast of Guerrero in extreme northeastern Coahuila and the adjoining part of Texas, especially Dimit and Webb Counties.

Various. accounts of mission foundations indicate that no Pacoa were present at either San Juan Bautista or San Bernardo when they were first established at Guerrero. No Pacoa are reported in the Census of 1734 at San Juan Bautista, but in the 1772 census (Rodríguez 1772b:123-127) 10 individuals are identified as "Pacoa" and one as "Pacoatal," probably a variant of the name Pacoa. Included 
among the 11 individuals are 6 adult males, 2 adult females and 3 children, 1 male, 2 female. Spouses are identified as "Coyota" (Spanish-Indian hybrid), "Messcal," "Panpopa" (Pampopa) and "Pastalacto". (Pastaloca).

At San Bernardo the Pacoa are identified in both censuses. In the 1734 census (Garza Falcón 1734a:21-24), six individuals (five adult males and one male child) are identified as "Pacos," "Pacuas," and "Paquas." The census of 1772 (Rodriguez 1772a:65-70) shows a notable increase- in numbers, 26 individuals, a 11 identified as "Paćo." Included are 8 adult males, 12 adult females, and 6 children, 2 male, 4 female. Spouses are listed as "Chaguan" (Siaguan), "Huacicil". (Guachichil), "Jacao," "Malaguito," "Minicu" (Manico), "Pachal," "Paquachi" (Pacuache), "Papanac," and "Passtaloc" (Pastaloca).

Pacuache. The name Pacuache has been recorded in at least 45 different ways, some of them clearly the result of clerical and typographical errors. The range of forms is illustrated by the following: Nacuache, Pacahuche, Pacuachiam, Pacuasian, Pacuazin, Pacuche, Pagnache, Paguachi, Pajuache, Paquachi, Paquasian, Paquatche, Pascuache and Taguache.

The pre-mission territorial range of the Pacuache, which is fairly well documented, was confined to an: area north and northeast of Guerrero across which flow the Nueces, Leona and Frio Rivers (Foik 1933:9-10; Gómez Canedo 1968:8-9, $160,236,281-282,306$; Hoffmann 1935:44-45 and 1938:314; Maas 1915:34,51;

Sevillano de Paredes 1726:40-41; Shelby 1923:177; Tous 1930a:6; Wheat 1957,I: Map No. 115). In 1684 Dominguez de Mendoza (Bolton 1916:340) either met or heard of "Puguahianes" when he was in the western part of the Edwards Plateau of Texas. This suggests that at times the Pacuache ranged northward into the Edwards Plateau, possibly for seasonal bison hunting. "Two groups, Sacuache and Tepacuache, known only from a single source of 1693 (Gómez Canedo 1968:282), were seen near Pacuache on the Nueces. River northeast of Guerrero and may be subdivisions of the Pacuache.

Some of the Pacuache entered various missions of Coahuila and Texas, but most of them preferred San Bernardo of the Guerrero area. Two Pacuache are recorded in the baptismal register of Mission San Francisco Solano for the years 1712 and 1716, when the mission was at San Jose. One of these is an eight-year-old girl identified as a "Paquasia." The other is an adult female, married to an "Xarame," identified in one entry as a "Paquasia" and in another as a "Paquache" (Solano Registers).

The Pacuache seem to have been the dominant group at Mission San Bernardo during the 1720s. In 1727 Sevillano de Paredes (1727:50) stated that some 350 Pacuache had left the mission because of a food shortage. The census of 1734 (Garza

Falcón 1734a:23), however, suggests that few of the Pacuache had returned. This census records only five Pacuache individuals, three adult males and two children, listed as "Paquachi" and "Pacuache." After this the Pacuache evidently returned to San Bernardo in considerable numbers, for in the 1772 census (Rodriguez 1772a: 66-73) 85 persons are identified as either "Paguachi" or "Paquachi." - Of these, 37 are adult males, 28 are adult females and 20 are children, 14 male and 6 female. Spouses include "Aguayam" or "Aguayan," "Canoa" (Canua), "Huacacil" (Guachichi1), "Jacao," "Minicau" (Manico), "Ocam"- (Ocana), "Pacó" (Pacoa), other 
"Paquachi," "Passtancoya," "Patacal," and "Paxac" (Paac).

Some Pacuache entered Mission San Antonio de Valero at San Antonio, Texas, whose registers permit identification of at least 13 Pacuache individuals between the years 1722 and 1766 (Valero Registers). One of these was previously at San Francisco Solano. A few of the Pacuache from San Antonio de Valero were briefly (1749-1755) at Mission San Ildefonso in present Milam County northeast of Austin, Texas, serving as teachers and interpreters (Bolton 1915:202; Gilmore 1969:49-50).

Enough evidence has been recorded to indicate that the Pacuache, when first known to Europeans, had a population of about 400. In 1708 Espinosa (Maas 1915: 34) stated that the Pacuache population at that time totalled more than 300 individuals, and in 1727 Sevillano de Paredes, as noted above, wrote that about 350 Pacuache bad been at San Bernardo. Garcfa (1760:title page) named the Pacuache on a short list of groups who spoke dialects of the Coahuilteco language. A few details on Pacuache culture appear in various sources cited above: hunting of bison, deer, rats and mice; use of bow and arrow; temporary settlements, usually shared with other groups, in wooded areas near streams; one house form (poorly described), apparentily a lean-to, made of branches covered with grasses, open on one side; hides processed by women and decorated with designs in red and yellow paint; smoke signaling; horses stolen at night from a Spanish travel party; decorated hides and other unspecified items traded to Spaniards and Indians at the Guerrero mission center.

In Hodge $(1910, I I: 183,191-192,1115)$ the Pacuache have received very confused treatment. "Pacuaches" and "Pacuachiam" are erroneously given as names of two separate Indian groups, and various group names and name variants are also erroneously equated, either directly or indirectly, with "Pacuaches":

Paachiques, Pacaos, Pachagues, Pachao, Pachaques, Pachoches, Pacoas, Pacos, Pacuas, Paikawa, Paikawan, Pakawa, Pakawai, Parchaques and Tompacuas.

Pamajo. The census taken in 1734 at San Bernardo identifies two individuals as Pamajo, a man and his young daughter (Garza Falcon 1734a:21). The man's wife is not ethnically identified. No identical or even closely similar group names have been found in other documents, and at present there is not enough evidence to relate it to somewhat similar group names, such as Pamache and Pamaque.

Pamasu. In 1727 Sevillano de Paredes (1727:49) gave the name Pamasu on a list of five Indian groups then represented at Mission San Bernardo, but the censuses of 1734 and 1772 do not identify any Pamasu at this mission. A document of 1675 (Porti1lo 1886:175), written at Monclova, Coahuila, lists the names of 18 Indian groups who had sent representatives to confer with Spanish officials. One name on the list is Pamafeo, which may be a misreading of Pamaseo (handwritten 6 and $s$ of that period are similar). If so, Pamasu and Pamaseo may refer to the same Indian population. Another possibility is that Pamasu may be equivalent to Pomuzeno, the name of a group represented by one individual at nearby Mission San Juan Bautista in 1772. Little can be said about the probable aboriginal location of the group or groups represented by these names. 
Pampopa. The name Pampopa has been recorded in at least 16 different ways, including Campoa, Pampo, Pampoa, Pampoca, Pampoja, Pamposa, Pampoja, Panpoc, Pompopa and Pumpoa. The pre-mission territorial range of the Pampopa is fairly well documented, and extended from the Medina River near San Antonio southward and southeastward almost to the Rio Grande. They were most commonly reported as living along the. Frio and Nueces Rivers, particularly in the area now covered by Dimmit, La Salle, and McMullen Counties (Maas 1915:36-37; Sevillano de Paredes 1727:42-43,48; Shelby 1923:177-179; Tous 1930b:4-5; Wheat 1957; I:Map No. 149).

The Pampopa entered missions at Guerrero (San Juan Bautista) and at San Antonio (San José y San Miguel de Aguayo). In the San Juan Bautista census of 1734 (Garza Falcón 1734b:17-18), six Pampopa (three adult males and three children) are listed under three name variants: "Campoa," "Pampoa," and "Pumpoa." Portillo (1886:283) cites a document which indicates the presence of nine Pampopa at San Juan Bautista in 1738. The San Juan Bautista census of 1772 (Rodriguez 1772b:123-129) indicates the presence of 31 "Panpopa": 14 adult males, 8 adult females and 9 children, 5 male and 4 female. Spouses are identified as "Achoj," "Achogtatal," "Cacsaputal" (Cachopostal), "Campacuas," "Messcal," "Paccoa," "Pita," "Pachsa" (Patzau), other "Panpopa," and "Coyota" (Spanish-Indian hybrid).

Little is known about the number of Pampopa who entered Mission San José y San Miguel de Aguayo at San Antonio. They seem to have entered this mission when it was founded in 1720 (Dabbs 1940:8; Forrestal 1931:20-21; Habig 1968:83,85, 271).

Sevillano de Paredes $(1727: 42-43,48)$ estimated that about 500 Pampopa were still living along the Nueces River in 1727, but this figure may include remnants of other groups associated with the Pampopa. García (1760:title page) listed the Pampopa among the groups that spoke dialects of the Coahuilteco language. Very few cultural details were recorded for the Pampopa, but the following may be cited: frequently moved temporary encampments and gathering and storage of pecans for food (Campbell 1975:18-19; Tous 1930b:4-5,10-11). .

Papanac. At least 23 variants of the name Papanac occur in various documents. Those found onty in primary sources include Panac, Papan, Papanac, Papanaca, Papanacam, Papanaque, Papani, Papanico, Paponaca, Paponal and Popan. The remainder, all similar to the preceding, represent errors made in secondary sources.

Papanac individuals and families were present at two of the Guerrero missions, San Francisco Solano and San Bernardo. It is clearly indicated that some Papanac were present when San Francisco Solano was established at Guerrero in 1700 (Cuervo y Valdés 1700b:24-27; Weddle 1968:31). Later, in 1706-1707, after this mission had been moved westward to San Ildefonso, three Papanac individuals were recorded in the baptismal register. All were adult females, two of them having Xarame husbands (Solano Registers). In 1708 Espinosa (Maas 1915:37) reported that some of the Papanac were still living under native conditions somewhere north of the Guerrero mission center.

Identified in the census taken at San Bernardo in 1734 (Garza Falcón 1734a:20, 23) are five Papanac individuals, two adult males and their three children. One of the men was serving as governor of the mission Indian village in that 
year. In the census report of 1772 at the same mission (Rodriguez 1772a:65) three Papanac adults appear, two males and one female. Their spouses are listed as "Aguayan," "Pacó" (Pacoa) and "Jalam" (Xarame).

Some Papanac also entered Mission San Antonio de Valero at San Antonio, Texas. In the various mission registers covering the years 1727-1764, at least 19 different Papanac individuals are identified (Valero Registers); and a document of 1772 (Leutenegger 1977:25-26,28) indicates that three Papanac individuals, all male, were still living at this mission. One female, who was buried at San Antonio de Valero in 1739, is said to have been baptized at San Francisco Solano, indicating that at least some Papanac followed San Francisco Solano to its fourth and final location, at San Antonio, where it was renamed San Antonio de. Valero. It would appear from the evidence summarized above that not many Papanac took up permanent residence at missions.

The most informative pre-mission records of the area place the Papanac along the Nueces, Leona and Frio Rivers between Guerrero and San Antonio, particulariy in the area now embraced by parts of Dimmit, Zavala and Frio Counties, Texas (Gómez Canedo 1968:160,236; Hatcher 1932:53; Mazanet 1957:356). It is probable that, prior to Apache expansion southeastward, the Papanac also at times ranged northward into the Edwards Plateau, since in 1684 Domínguez de Mendoza met or heard of "Papanes" when he was in the western portion of the plateau (Bolton 1916:339-340; W117iams 1962). It is also probable that the Papanac at times ranged southward across the Rio Grande into northeastern Coahuila, but the only indicator of this is a document of 1675 published by Porti17o (1886:175). The observations of Mazanet on languages spoken in southern Texas suggest that the Papanac were among those who spoke a Coahuilteco dialect (Gómez Canedo 1968:240).

Pastaloca. Documents pertaining to the Guerrero missions make it possible to clear up some of the confusion that surrounds the Pastaloca. Pastaloca and Pachaloco have usually been regarded as names for two separate ethnic groups (Branda 1976:682,707-708; Hodge 1910, II:183,204; Swanton 1940:135 and 1952:310). Ruecking (1954a:4,19 and 1955a:332,342,346-347) 1isted Pastaloca as a synonym for Pachaloco but did not specify any reasons for making such a judgment. I have re-analyzed the evidence, some of which Ruecking did not use, and it now appears that his apparently intuitive judgment is correct. Since the documentary sources are relatively abundant for the name Pastaloca and rare for Pachaloco, it is here suggested that Pastaloca be used as the primary name and that Pachaloco be regarded as a synonym. Actually, as will be shown below, Pachaloco is an erroneous distortion of the name Pastaloea that entered the record relatively late in time and was repeated so often thereafter that it came to be regarded as the name of an Indian group separate from Pastaloca.

The pertinent evidence has to do with the orthography of Indian group names associated with Mission San Juan Bautista. Basic documents, to be cited later, of the years 1708,1727, 1734 and 1738 , all refer to the Pastaloca as a major group represented at this mission. Pachaloco first occurs in a document of 1762. Later, in a census of 1772, Pastaloca returns to the record in nine recognizable name variants. Finally, during an inspection trip of the northern provinces in 1777-1778, Morfi saw at San Juan Bautista the document of 1762, the only other document of the eighteenth century that. contains the name Pachaloco. Morfi's recording of Pachaloco for San Juan Bautista was thereafter used in 
secondary sources, along with Pastaloca, giving rise to the belief that two ethnic groups bearing the names Pastaloca and Pachaloco were represented at San Juan Bautista.

No other name similar to Pachaloco seems to have been recorded at other Spanish missions of the general area, with the possible exception of a name recorded at Mission Nuestra Señora de la Purisima Concepción de Acuña at present San Antonio, Texas. In the fragmentary records of this mission, seven "Pachalaque" individuals are identifiable between the years 1733 and 1756. Ruecking (1955a:346347) believed that Pachalaque, Pachaloco and Pastaloca were synonymous names for the same Indian population. He may again be correct, but as yet I have not encountered enough evidence to demonstrate a valid linkage of Pachalaque with Pachaloco/Pastaloca.

The Pastaloca were seen by Mazanet in two shared encampments in 1690 and again in 1691 (Gómez Canedo 1968:160,235; Hatcher 1932:52; Mazanet 1957:354). They were recorded under the names "Pastaluc" and "Pastulac." The locale in 1690 was the central part of present-day Zavala County, Texas. In 1691 it was arroyo de Caramanchel, considered to be present Comanche Creek of Zavala County. Thus the Pastaloca territorial range at this time included lands between the Nueces River and the Rio Grande northeast of Guerrero. A11 later records refer to Pastaloca at missions of Coahuila and Texas.

When Mission San Juan Bautista was moved from the Rio Sabinas to the Rio Grande in 1701, it appears that no Pastaloca were initially present. Some arrived shortly before 1708, however, for in that year Espinosa (Maas 1915:33) reported that over 100 "Pastaloques" had recently entered the mission. In an inspection report of 1727 . Sevillano de Paredes indicated that "Pastalocas" were among the three most numerous Indian groups represented at San Juan Bautista (Sevillano de Paredes 1727:42; Weddle 1968:174).

In the census taken at San Juan Bautista in 1734, six "Pastaloca" were recorded: three adult males, one of them having three children of unspecified sex (Garza Falcón 1734b:15,17-18). Portil10 (1886:283) refers to a document of 1738 which reported 71 "Pastalocos" at San Juan Bautista. The census of 1772 (Rodríguez 1772b:123-127,129) identifies 20 individuals whose recorded ethnic names are probably all variants of the name Pastaloca: Passtacalo, Passtaculo, Passtalaco, Passtalca, Passtaloca, Passtaloco, Pastalacto, Pastaloco and Pataloco. Of these 20 individuals, 9 are adult males, 5 are adult females and 6 are children, 3 male and 3 female. The spouses are ethnically identified as "Campacua," "Maraquite" (Malaguita), "Messcal," "Messtiza" (Spanish-Indian hybrid), "Pacoa," and "Patacalo" (Patacal). One of the adult males was serving as governor of the mission Indian village in 1772.

It was in an inspection report at San Juan Bautista, written in 1762, that the name Pachaloco was first used to refer to the Pastaloca (Ximénez:1726b:106), and Morfi's almost verbatim phrasing drawn from this 1762 report reveals how the confusion concerning Pachaloco and Pastaloca was initiated (Morfi 1856:440441; Orozco y Berra 1864:303).

In the absence of primary documents on the foundation of Mission San Bernardo in 1703, it cannot be established that any Pastaloca were there from the beginning. In 1727 Sevillano de Paredes (1727:46; Weddle 1968:175) listed 
"Pastalocas" among the five principal Indian groups represented there. The 1734 census taken at San Bernardo identifies 15 individuals as either "Pastaloco" or "Pactaloco." Included are five males, each of whom had two children (sex unspecified). Ethnic affiliations of wives are not recorded (Garza Falcón 1734a:21-22). The 1772 census identifies only nine individuals as "Passtaloc" or "Pastaloc": three adult males, four adult females, and two children, both male (Rodriguez 1772a:67-73). Spouses identified include "Aguayan," "Canoa" (Canua), "Chaguan" and "Chajuanahan" (Siaguan), "Juanca," and "Pacó" (Pacoa).

Few Pastaloca seem to have entered the San Antonio missions. Two "Pastaloca" females are identified (1733) in the records of Mission San Antonio de Valero (Valero Registers). Mazanet's comments on languages spoken between Guerrero and San Antonio suggest that the Pastaloca spoke a dialect of Coahuilteco (Gómez Canedo 1968:240).

Pastancoya. The Pastancoya seem to have been first recorded in the middle seventeenth century under the names "Pastanquia" and "Pestanquia" (León y otros 1961:189-190). Each name appears on a long list of Indian groups, one said to be native to the Monterrey area (most likely northward from Monterrey), and the other said to be native to the vicinity of Cerralvo, an early Spanish mining settlement. Cerralvo, which still exists as a community, is nor.theast of Monterrey and about halfway between Monterrey and the Falcon reservoir on the Rio Grande. If the early Pastanquia are the same and the Pastancoya of a period some 50 years later, their original territorial range was probably in northern Nuevo León and adjacent parts of Texas. Orthographically all later variants of the name closely resemble Pastancoya.

Some doubt arises as to whether or not any Pastancoya individuals and families were actually at San Bernardo. when this mission was officially established in 1703. Nineteenth-century writers (Bancroft 1883, I:611; Orozco y Berra 1864: 303; A. L. Velasco 1897, XIX:14) list them as present, but the eighteenthcentury documents do not. In 1708 Espinosa (1708:42-43; Maas 1915:36-37) did not mention any Pastancoya at San Bernardo, but he included the name on a long list of Indian groups which at that time were living in an easterly direction from San Bernardo. Apparently some of the Pastancoya first entered San Bernardo between 1708 and 1727, for in 1727 Sevillano de Paredes reported that approximately 100 Indians, including some Pastancoya, had previously fled from the mission and were then living about 40 miles down the Rio Grande at a place called El Carrizo (Sevillano de Paredes 1727:49-50; Weddle 1968:175). The El Carrizo locality must have been roughly midway between modern Guerrero and Laredo. The Pastancoya evidently had moved in a direction which took them nearer to their postulated homeland noted above.

After deserting San Bernardo sometime prior to 1727, it does not appear that all of the Pastancoya fugitives returned to the mission. The census of 1734 (Garza Faicón 1734a:20-21) identifies onily eight Pastancoya (rendered variously as "Pastancoiam," "Pastancoian," and "Pastancoya"): four adult males, two of whom had a total of four children. The census of 1772 (Rodriguez 1772a: 69-71) lists five Pastancoya: four adult males and one female child. Thereafter the Pastancoya disappear from primary documents. 
Modern investigators who have been concerned with Tinguistic affiliation have suggested that the Pastancoya probably spoke a dialect of Coahuilteco (Hodge 1910, II:208; Powel1 1891:69; Ruecking 1954a:19; Swanton 1940:135). As noted above, there is evidence which suggests that the Pastancoya originally lived in northern Nuevo Leôn, and it is possible that they spoke another language before being fragmented and displaced by Spaniards, perhaps the Quinigua language recognized by Hoyo (1960) and Gursky (1964). The few Pastancoya at Mission San Bernardo could have become bilingual as the result of a half century of association with Coahuilteco-speakers.

Patacal. The Guerrero mission documents permit a better definition of the Patacal, whose name has been confused with names and name variants of other groups, particularly Pastaloca, Pasteal and Patcal (Branda 1976:708; Hodge 1910 , II $: 208,1117)$. Apparently the Patacal did not enter any other missions.

The Patacal were first noted in 1727 by Sevillano de Paredes (1727:42-43), who said that "Patacales" had been at Mission San Juan Bautista but had recently left and were living south of the Nueces River some 55 to 60 miles east of the Guerrero mission center. He placed the Patacal somewhat to the south of the Pampopa who, he said, lived along the Nueces River, probably in what is now eastern Dimmit and western La Salle Counties, Texas. From this it may be surmised that the Patacal were at that time associated with one or more southern tributaries of the Nueces River in the two counties named. San Roque Creek and Las Raices Creek are possibilities. Sevillano also said that the Patacal in 1727 numbered about 400. If this population estimate is reasonably accurate, it would seem that the Patacal were still relatively numerous as late as 1727.

Later records indicate that some of the Patacal eventually entered two of the Guerrero missions, San Bernardo and San Juan Bautista. In the San Bernardo census of 1734 (Garza Falcón 1734a:21), six "Patacal" are identified: two adult males and four children of unspecified sex. In the 1772 census at the same mission (Rodríguez 1772a:66-70), 12 individuals are identified variously as "Patacal," "Patacalh," and "Pattacal": 6 adult males, 1 adult female and 5 children, all male. Spouses are listed as "Pachal," "Paquachi" (Pacuache), and "Paxaguis" (Paac).

At San Juan Bautista no Patacal were recorded in the 1734 census, but in the 1772 census (Rodriguez 1772b:123-124,127-129), 14 individuals are identified by the following groups names: Pachtacal, Pachstacal, Paschtacal, Pasthtal, Patacal and Patacale. Since the first four names resemble Patacal more than they resemble the group names of other Indians at this mission, it is assumed that they are variants of the name Patacal. Of these 14 individuals, 7 are given as adult males, 3 as adult females and 4 as children, 2 of each sex. Spouses are listed as "Messcal," "Passtalca" (Pastaloca), and "Maraquita" (Malaguita).

Pataguo. In various documents the name Pataguo occurs in at least 25 forms, the main variations appearing in the terminal syllables, as shown by Patagu, Patagahu, Pataguac, Pataguaque, Patahua, Patao, Patau, Patavo, Pato and Patou. 
Swanton (1940:135) has listed "Patague" and "Patou" as names for separate groups, but no evidence has been found to support this distinction. Such data as are available indicate that the Pataguo pre-mission territory was north of the Rio Grande, northwest, north and northeast of Guerrero. There seems to have been an eastward shift, possibly the result of Apache pressure, since the later sources place the Pataguo along the Nueces and Frio Rivers northeast of Guerrero (Bolton 1916:297; Figueroa Torres 1963:105; Gómez Canedo 1968:160,236; Griffen 1969:164; Hatcher 1932:53; León y otros 1961:219; Maas 1915:36; Tous 1930a:7).

Most of the Pataguo who entered missions went to San Antonio de Valero at San Antonio, Texas, in whose records at least 31 Pataguo individuals can be traced between 1720 and 1763 (Valero Registers). Smal1 numbers of Pataguo are identified in each of the three missions established at Guerrero. In 1707, when San Francisco Solano was at San IIdefonso, one adult male "Pataguo" was recorded; and in 1712 and 1716, when the same mission was at its San José location, two more adult males were recorded, one designated as "Pataguo," the other as "Pataguan." The latter was married to an "Xarame" (Solano Registers). In the census of 1734 at San Juan Bautista, two "Pato" were identified, an adult male and his daughter (Garza Falcón 1734b:16), and in the San Bernardo census of the same year four individuals were identified as "Pataguo": three adult males and one male child (Garza Falcón 1734a:22-23). The few Pataguo at the Guerrero missions obviously could not maintain an ethnic identity very long, and this is supported by absence of Pataguo in the 1772 census reports.

Mazanet's statements about Indian languages spoken northeast of Guerrero suggest that the Pataguo may have spoken a dialect of Coahuilteco (Gómez Canedo 1968:240).

Patzau. At least 40 variants of the name Patzau can be found in Spanish documents and the range is indicated by the following: Paceo, Pacha, Pachao, Pachaug, Pacho, Paisau, Pazagual, Pasajo, Pasxa, Pattsou, Patzar, Pauchau, Paza, Pazajo, Psaupsau and Pucha. Swanton (1940:135) and Ruecking (1955a:344-347) have listed "Pachaug," "Psaupsau," and "Patzau" as names of three different Indian groups, ignoring Hodge's $(1910,11: 1114,1123)$ equation of the three names. Analyses of mission records reveal that the three names are synonymous.

Pre-mission records of the Patzau are few in number, but clearly place them in Texas northeast of Guerrero, particularly between the Nueces and Frio Rivers (Gómez Canedo 1968:160,236; Hatcher 1932:53; Mazanet 1957:352). The name "Pucha" was recorded in 1684 when Domínguez de Mendoza was in the western part of the Edwards Plateau (Bolton 1916:339-340), which suggests that the Patzau may at times have ranged northward onto the Edwards Plateau.

In 1708 Espinosa stated that "Pazaguales" were present at San Bernardo (Maas 1915:33), and this is confirmed by the census of 1734 in which three individuals are identified as "Pacsagual" and "Pasagual": two adult males and one male child (Garza Falcón 1734a:22). One female "Pazhajo" was baptized at Mission San Francisco Solano in 1712, when this mission was located at San José (Solano Registers). Three "Pachsa" appear in the 1772 San Juan Bautista census report: an adult male and his two children, one male, the other female (Rodríguez 1772b: 124). Most of the Patzau who entered missions went to San Antonio de Valero at 
San Antonio, Texas, whose registers permit identification of at 7 east 48 individuals between the years 1720 and 17.65. One Patsau male at San Antonio de Valero is, in various register entries, recorded as Pachajuen, Pachcagua, Pacsau, Pazahu, Pazajo and Pazau. (Valero Registers).

Locational data and Mazanet's observations on languages spoken in southern Texas suggest that the Patzau spoke Coahuilteco.

Pausane. Some 15 variants of the name Pausane have been encountered in Spanish doucments, among them Paisano, Paufane, Pauxane, Paysan and Pauzano. The Pausane pre-mission territory is not clearly recorded, but at various times after 1700 they were said to be living at localities in a fairly large inland area between the lower San Antonio River and the Rio Grande, and also extending a short distance across the Rio Grande into present northern Tamaulipas (Esçandón 1751:19-20; Maas 1915:36-37; Sevillano de Paredes 1727:49-50,55).

In 1708 Espinosa stated that some "Paisanos" were present at Mission San Bernardo but that others were still living under native conditions east of the Guerrero missions in the lower part of southern Texas (Maas 1915:33,36-37). Later, in 1727, Sevillano de Paredes $(1727: 49-50,55)$ said that about 100 "Pausanes" were in southern Texas, and farther along in the same document he referred to the Pausane as numbering about 300 and Tiving somewhere on the lower San Antonio River of Texas. Few of the Pausane seem to have remained very long at San Bernardo, for the census of 1734 (Garza Falcón 1734a:23) identified only two adult "Paysano," and that of 1772 identified none.

In 1723 one "Paisan" was baptized at Mission San Antonio de Valero of San Antonio (Valero Registers). Many of the Pausane of lower Texas were persuaded by missionaries to move westward and enter Mission San Francisco Vizarrón de los Pausanes in northeastern Coahuila when it was established in 1737 near present Villa Unión (Guadalupe 1754:173-183; Morfi 1856:435-436). In 1778 the Pausane at this same mission were said to be living in a village consisting of 12 houses (Anónimo 1778:202-203). It is the presence of Pausane at Mission San Francisco Vizarrón which earlier led me to assume that the Pausane were native to northeastern Coahuila (Branda 1976:711-712).

After 1750 some of the unmissionized Pausane entered Mission San Augustin de Laredo near Camargo, Tamaulipas. Escandon (1751:20) stated that 18 "Paysanos" were present there in 1751 and that they had come to this mission from both sides of the Rio Grande.

Garcia (1760:title page) indicated that "Pausanes" were among the missionized groups that spoke a dialect of Coahuilteco. Whether they originaliy spoke Coahuilteco or had learned it in missions cannot be determined.

Pausaqui. Two Pausaqui individuals were recorded at San Francisco Solano in 1713, when the mission was located at San José. They consist of an adult male and his newly born son; the wife is listed as a "Paiuguan" (Payuguan). Hodge (1910, II:426) does not have an entry for Pausaqui and merely gives the name on a list of Indian groups said to have been represented at Mission San Antonio 
de Valero of San Antonio. The name Pausaqui does not appear in the Valero registers, and it seems evicient that the records of Valero were confused with those of Solano. The only known occurrence of the name Pausaqui is in the baptismal register of San Francisco Solano (Solano Registers). Swanton (1940: 135), however, has listed Pausaqui as the name of an ethnic group. Ruecking (1955a:347) has equated Pausaqui with the name Pausay, but no evidence is cited in support of this equation. Pausaqui is undoubtedly a variant of some better known group name, such as Paachiqui, Pachaque, or Pausay, but at present not enough evidence is available to establish a linkage.

Payaya. Some Payaya were present at Mission San Francisco when it was still Tocated at Guerrero, as is indicated by 01 ivares $(1700: 49)$, who reported that in 1700 at least 14 Payaya males were killed in an attack on the mission by unidentified hostile Indians. Later, after this mission was moved to San I7defonso, two "Payaya" were baptized in 1706-1707: two adults, one male, the other female (Solano Registers).

For Mission San Juan Bautista, one "Payaya," an adult male, was reported in the census of 1734 (Garza Falcón 1734b:17), and in the census of 1772 (Rodrifguez 1772b:125), two "Payaya" were reported: an adult male and his son, the man listed as married to a "Canpacuas." For Mission San Bernardo no Payaya were reported until the census of 1772 (Rodriguez 1772a:68,73): six individuals, two adult males and four children, two male, two female. Most of the Payaya entered Mission San Antonio de Valero at San Antonio. At least 184 Payaya individuals can be traced through the Valero records between the years 1719 and 1789 (Valero Registers).

The known pre-mission range of the Payaya extended from the vicinity of San Antonio southwestward to the Frio River, but after 1700 a few Payaya were reported to be living northeast of San Antonio near the junction of the Little and Brazos Rivers. Most of what is now known about the Payaya has been summarized by Campbe11 (1975).

Payuguan. Approximately 40 forms of the name Payuguan appear in Spanish documents, and the range of variation is suggested by the following sample: Paiabun, Paiugan, Paiapan, Pajuguan, Pallugan, Payagua, Payahan, Payavan, Payoan, Payuhuan, and Poyoguan.

Although not abundantly documented, the pre-mission range of the Payuguan apparently covered a rather large area in extreme northeastern Coahuila and the adjoining part of Texas, extending from the Rio Sabinas below present Lago de Don Martin northward across the Guerrero section of the Rio Grande and then north-northeastward across the Nueces and Frio Rivers (Bolton 1916:339-340; Gómez Canedo 1968:160,236; Hatcher 1931:53; Maas 1915:16,18,23,29,36-37; Wedd $e$ 1968:31-32,108-109). The size of this territory seems to be reflected in the recorded presence of Payuguan at so many Spanish missions. The Guerrero locality was probably not far from the geographic center of the Payuguan territorial range. 
Some Payuguan were represented at San Juan Bautista when it was initially estabI ished on the Rfo Sabinas south of Guerrero in 1699 (San Buenaventura y Salazar 1708:15), and in the same year other Payuguan were reported at Mission El Dulce Nombre de Jesús de Peyotes west of Guerrero near present Villa Unión, Coahuila (Cuervo y Valdés 1699:230,233-234). When San Juan Bautista was moved to Guerrero in 1701, the Payuguan moved with it (San Buenaventura y Salazar 1708:17), but the censuses of 1734 and 1772 reported no Payuguan at San Juan Bautista. A few Payuguan are said to have entered San Bernardo (Espinosa 1746:483), but no date is indicated and the censuses of 1734 and 1772 reported no Payuguan there.

Various documents establish the presence of Payuguan at San Francisco Solano when it was founded at Guerrero in 1700 (Cuervo y Valdés 1700b:24-27; Maas 1915:35-37), and the mission registers later identify nine Payuguan: four at the Guerrero location, three at San IIdefonso, and two at San José. These include three adult males, five adult females, and one female child, variously identified as "Paiuguan," "Payuhuan," and "Payuguan." Spouses are given as "Pausaqui" and "Xarame" (Solano Registers).

Payuguan also entered still other missions: Nuestra Señora de los Dolores de la Punta at Lampazos, northern Nuevo León (Maas 1915:18-23), San Bernardino de la Candela of eastern Coahuila (Bolton 1913:243,427), and San Antonio de Valero at San Antonio, Texas (10 individuals are identified in the VaTero registers between 1720 and 1745$)$.

A few details on Payuguan foodstuffs have been recorded: rats, prickly-pear fruits, and unspecified roots and fruits. Mazanet's statements on languages spoken within the Payuguan range suggest that they spoke a dialect of Coahuilteco (Gómez Canedo 1968:240).

Piedras Chiquitas. This name, also rendered as Piedras Chicas, is Spanish "Tittle stones"). In 1698 the group was mentioned by Cuervo y Valdés $(1698: 6)$ in a context which suggests that they originally lived somewhere in northern Coahuila. The name does not appear in registers of Mission San Francisco Solano, but San Buenaventura y Salazar (Maas 1915:54-55; Weddle 1968:54-55) noted that some of the Piedras Chicas were at this mission when it was located at San Ildefonso. As the name is missing from the Solano registers, it is possible that the Spanish name refers to one of the groups listed by a native name.

Piniquu. One Piniquu female of unspecified age was recorded at San Francisco Solano in 1704, when the mission was still at Guerrero (Solano Registers). The name occurs in no other Spanish documents, although it is mistakenly said to occur in the baptismal records of Mission San Antonio de Valero of San Antonio, Texas (Hodge 1910,II:426). Bolton (in Hodge 1910, II:256) equated Piniquu with Minicau (Manico), but this is evidently based upon the slight similarity in names. He failed to note that Piniquu and Minicau individuals were baptized on the same day at San Francisco Solano. Absence of the name from documents referring to areas east of Guerrero suggests a more westerly placenent of the Piniquu territorial range. 
Pita. Establishing a clear identity for the group recorded as Pita is difficult because of certain complications. Pita occurs as the first two syllables in two other recorded group names of the same general area, Pitahay and Pitalac, and this suggests that Pita may at times have been a contracted form of either Pitahay or Pitalac. Pita is also a Spanish word with several meanings, one of which is the name for the maguey or century plant, an important food and fiber resource in both aboriginal and modern Mexico. Thus it is possible that Pita is not a name of Indian origin but a name given to a specific Indian group by Spaniards.

The population here referred to as Pita was probably first recorded in 1708 by San Buenaventura y Salazar (Mass 1915:23), who listed "Pittales" as one of nine Indian groups that spoke the same unidentified language and lived along both sides of the Rio Grande in an easterly direction from Mission Nuestra Senora de los Dolores de la Punta near present-day Lampazos, northern Nuevo León. Individuals from these nine groups, he wrote, came to Dolores to visit relatives and trade. The "Pittales" of this document could have been the Pitalac, but Pita seems to be the better identification, since the Pita are mentioned in this and later documents as being represented in the mission Indian population of Nuestra Señora de los Dolores. Elsewhere (in Branda 1976:736) I have identified these "Pittales" as Pitalac, but this interpretation now seems to be untenable.

Just where the nine groups were living on the Rio Grande cannot be determined with precision. If the phrase por partte del Oriente is taken literally, map study shows that the section of the Rio Grande east of Lampazos includes stretches of the river both upstream and downstream from modern Laredo, Texas. This would place the "Pittales" (Pita) and their associates in an area that includes parts of northeastern Coahuila, extreme northern Nuevo León, and the northwesternmost extension of Tamaulipas, as well as adjacent parts of Texas, mainly Webb County but possibiy also western Zapata County.

In 1727 Sevillano de Paredes (1727:54-55) visited Mission Nuestra Señora de los Dolores and reported that its Indian population at that time consisted of 50 individuals which he identified as "Pitas" and "Pajalves." These Pita must therefore have entered Dolores sometime between 1698, when the mission was estab1ished, and 1727, the year of Sevillano's mission inspection. In 1708 San Buenaventura y Salazar had failed to indicate if any Pita were then living at the mission, but he did specify the presence of several groups previously said to be associated with the Pita.

Few Pita were recorded at missions north of Lampazos. In 1727 one adult male "Pita" was baptized at San Antonio de Valero of San Antonio, Texas (Valero Registers). Portillo (1886:283) quotes from a document of 1738 which indicates that two familites of "Pitas" were then living at San Juan Bautista, and the census of 1772 identifies one adult male "Pita" still living at the same mission (Rodriguez 1772b:123). In 1793 Lafora (1939:196-197) listed the names of Indian groups represented at nine missions of Coahuila, and the name "Pitas" appears on the 11st. Among the Coahuila missions he visited was San Juan Bautista. This is the last reference to living Pita that has been found. 
Pitahay. The Pitahay are known in Spanish documents by at least eight notably similar names: Pitahaya, Pitajaya, Pitanay, Pitijaya, Piutaay, Putai, Putaay and Putay. This name may have been given to the group by Spaniards or it may be a native Indian name that fortuitously resembled the Spanish word pitahaya ("night-blooming cereus"). The earliest known references to the Pitahay are provided by Mazanet who, while traveling in 1690 and again in 1691, encountered them on the present Frio River, evidentiy in or near Frio County, Texas, where "Putaay" were associated with i5 differently named Indian groups (Gomez Canedo 1968:160,236; Hatcher 1932:53; Mazanet 1957:356).

In the year 1708, Espinosa (Maas 1915:36-37) 1isted "Pitijayas" among the Indian groups then said to be living across the Rio Grande in a generalized easterly direction from the Guerrero missions, apparently in the same area indicated earlier by Mazanet. In 1713 an unspecified number of Pitahay families from the "north" were persuaded to enter Mission San Bernardino de la Candela of eastern Coahuila (Bolton 1913:423), but nothing further seems to have been recorded about these Pitahay. Thereafter a few Pitahay entered Mission San Bernardo, for in the census of 1734 (Garza Falcón 1734a:21,23) two families consisting of four individuals (two adult males, each with one young son) are identified as "Putaj" and "Putay." The spouses are not ethnically identified. Apparently the Pitahay at San Bernardo lost their ethnic identity prior to the Rodriguez census of 1772, which records no Pitahay at San Bernardo. Candela and San Bernardo are the only Spanish missions with which the Pitahay have been linked.

From the scant documentary record it would appear that the pre-mission territorial range of the Pitahay was entirely north of the Rio Grande. Mazanet's remarks on languages spoken in that area suggest that the Pitahay may have spoken a dialect of Coahuil teco (Gómez Canedo 1968:240).

A number of errors concerning the Pitahay should be corrected. Hodge (1910,II: 264,337) lists "Putaay" as the name of an Indian group separate and distinct from the Pitahay, which is not verifiable. This error has been perpetuated by Swanton (1940:135) and by Webb $(1952,1 \mathrm{I}: 382,421)$. The Pitahay, as interpreted by Ruecking $(1955 a: 347,354,356)$, should be disregarded, since through an apparent clerical error he gave data on "Pitahaya" under the heading "Pita," and also equated "Putaay" with "Pausay," for which no supporting evidence has been found. Ewers (in Berlandier 1969:101n) has suggested that "Pitales," a misreading of "Pitalac," is synonymous with Pitahay, but this is not supported by any evidence now available.

Pitalac. The name Pitalac is not mentioned in pre-mission documents of the general Guerrero area and is recorded only once, relatively late in time, in connection with one Guerrero mission. In the San Juan Bautista census of 1772 , one adult, unmarried male is identified as "Pitalac" (Rodriguez 1772b:129). This individual probably came from one of the San Antonio missions. According to various documents, the Pitalac were at least initially associated with three missions that had been moved from eastern Texas to San Antonio in 1731: Nuestra Señora de la Purísima Concepción de Acuña, San Francisco de la Espada and San Juan Capistrano. Three Indian populations said to total about 1,000 individuals (an estimate that is probably exaggerated) were persuaded to enter these San Antonio missions, the group names being designated as Pacao, Pajalat, and Pitalac or Pitalaque (summarized by Bolton in Hodge 1910, II:92-93,191,435-436). 
One source (Pérez de Mezquía 1731:36) indicates that the Pitalac were also known by an alternate name, Alobja. Bolton's summary states that the three Indian groups came from the Frio and Nueces Rivers, presumably meaning somewhere near the junction of the two streams. Two sources not cited by Bolton indicate that prior to 1731 the three groups lived west of the lower San Antonio River in the area now embraced by Bee and Goliad Counties, which is not far from the junction of the Frio and Nueces Rivers (Sevillano de Paredes 1727:49; Wheat 1957: Map No. 115).

Except for the Concepcion marriage register, the early basic records of the three San Antonio missions have not survived. Eight of the Concepcion register entries, dated 1733-1759, refer to four individuals (two males, two females) as "Patalca". (Concepción Marriage Register). Since the Pitalac were linked with Concepcion in documents of 1737 , it appears reasonable to equate the two names. If this interpretation is accepted, it is no longer necessary to consider Patalca as the name of a separate ethnic group of southern Texas, as has been customary for some time (Hodge 1910, II:93,182-183; Branda 1976:709; Ruecking 1955a:344). One alternative remains, however: Patalca could be a variant of the name Patacal; but the evidence cited above better supports the equation of Patalca with Pitalac. There appears to be no basis for equating Patacal with Pitalac.

Pomulum. The Pomulum were recorded under at least 13 additional names, all recognizably similar: Molia, Muliam, Pamoliam, Pamuliam, Pamulan, Pamulian, Pamuliem, Pamulies, Pamults, Pamulum, Panulam and Pomuluma. Hodge (1970, II:278) referred to them as "Pomuluma" and, at the time of writing, knew them from only one source (Orozco y Berra 1864:303). The Pomulum seem to have first become known to Europeans in 1670 as one of numerous Indian groups from the "north" that occasionally raided Spanish settlements in the Saltillo and Monterrey areas (Griffen 1969:164). Their native territorial range appears to have covered parts of extreme northeastern Coahuila, extreme northern Nuevo León, northwestern Tamaulipas, and the closely adjoining portions of Texas. Traveling Spaniards never reported visits to specific Pomulum encampments, and the Pomulum are known principally from documents written at Spanish missions of northeastern Coahuila and northern Nuevo León.

It is clear that some of the Pomulum were among the Indian groups that entered Mission San Bernardo when it was officially established in 1703 (Ximénes 1762a: 112-113; Morfi 19355:321). In 1708 Espinosa (Maas 1915:36-37) 1isted "Pamulies" among the groups then living across the Rio Grande in an easterly direction from modern Guerrero; and in the same year, although referring to an unspecified earlier time, San Buenaventura y Salazar (Maas 1915:23) also mentioned "Pamulies" as one of nine groups from the Rio Grande who spoke the same unidentified language and who visited relatives and traded at Mission Nuestra Señora de los Dolores near present Lampazos in northern Nuevo León. The nine groups were said to be living along the Rio Grande east of that mission, which would place them in the Laredo area.

Apparently very few Pomulum remained long at Mission San Bernardo. The census of 1734 identifies one adult male "Pamuliem" (Garza Falcón 1734a:22), and the census of 1772 identifies one "Pamulien," an adult female married to a "Huacacil" 
(Guachichi1)(Rodríguez 1772a:70). Some "Pamulies" are known to have entered Mission San Miguel de Aguayo, founded in 1675 near Monclova, but the time of mission entry is not recorded (Porti110 1886:251).

Pomuzeno. In the 1772 census taken at San Juan Bautista, one adult male, a widower, is identified as a "Pomuzeno" (Rodríguez 1772b:127). This name may refer to the same group as the Pamasu reported at nearby San Bernardo in 1727, but there is not enough recorded information to establish such an identity. See also Pamasu.

Samioj. In the 1734 census of the Indians at Mission San Bernardo, one adult male and his three children (sexes unspecified) are listed as de nacion Samioj (Garza Falcón 1734a:21). The name Samioj, as written by Garza Falcón, probabiy should have been rendered as "Sanioj," which is similar to the group name "Sonayan," also rendered in various excerpts from the same primary document as

"Sanafan," "Sanyau" and "Sonayau." In 1690, and in the Tocality where Mission San Bernardo was later, established, Mazanet encountered "Sanyau" with five other named Indian groups (Gómez Canedo 1968:160; see also Dr. Velasco 1958:318).

If this equation of Samioj and Sonayan is accepted, it may be said that their late seventeenth-century territorial range was probably along both sides of the Rio Grande in the area immediately surrounding Guerrero. No similar names have been found in other reports of the various Spanish expeditions that traveled northeastward from Monclova before or after 1690.

Hodge $(1910,11: 165)$ has suggested that the "Sonayan" (actually a misreading of Sonayau) may have been identical with the Kouyam (or Kouayon) recorded in 1687 by Henri Joutel, chronicler of the La Salle expedition to Texas. This suggestion is best disregarded, not only on phonetic grounds but also because Joutel (in Stiles 1906:126) placed the Kouyam northeast of Matagorda Bay, over 250 miles from the Sanyau location recorded by Mazanet three years later.

Siaguan. Over 50 variants of the name Siaguan can be found in various documents, both published and unpublished. A number of these are the result of clerical and typographical errors. The range of forms is shown by the following abbreviated 1ist: Chaguan, Chamaguan, Chauhan, Chiaguan, Choguan, Mahuame, Ohaguame, Sciaguan, Siaban, Tziaban, Xhiahuan, Xiguan and Ziaban. The original Siaguan territory extended from the Río Sabinas of northeastern Coahuila (below Lago de Don Martin) northward across the Rio Grande to the Nueces River northeast of Guerrero. On the east the Siaguan sometimes ranged as far as the Laredo area (Cuervo y Valdés 1701:8-9; Gómez Canedo 1968:160,235; Hatcher 1932:52; Maas 1915: 16,23-24; Mazanet 1957:354).

Some "Chaguan" were at San Juan Bautista in 1699 when this mission was first established on the Río Sabinas (Cuervo y Valdés 1700a:12,16; 1701:8-9,12-14), but few of these seem to have followed the mission when it was moved to Guerrero in 1701. The 1734 census (Garza Falcón 1734b:18) recorded only one adult male "Chaguan," and none was recorded in the census of 1772. 
At San Bernardo, however, more Siaguan were reported. The 1734 census report (Garza Falcón 1734a:20-22) identifies 17 "Chaguan:" 7 adult males and 10 chilren (sexes unidentified). The census of 1772 (Rodriguez 1772a:65-68) shows seven individuals as "Chaguan" and "Chajuanahan." Included are three adult males, two adult females and two children. Spouses are listed as "Jacao," "Pacó" (Pacoa) and "Pastaloc."

At least 24 "Claban," "Siaban" and "Slaguan" are identiffed in the baptismal register of San Francisco Solano (Solano Registers). Ten of these can be linked with the mission at its Guerrero location (17.04); the remainder (14) can be linked with its San I1defonso location (1706-1707). Of the 24 individuals, 15 are adult males, 4 are adult females, and 5 are children, 3 male, 2 female, ages 1 to 10 years. Only two spouses are identified: "Macapao" and "Xarame."

Siaguan also entered other missions: Nuestra Señora de los Dolores de la Punta at present Lampazos, northern Nuevo León (San Buenaventura y Salazar 1699:44), San Miguel de Aguayo at Monclova, Coahuila (Porti11o 1886:251), and San Antonio de Valero at San Antonio, Texas. At least 49 Siaguan individuals can be traced through the San Antonio de Valero registers from 1720 until late in the century, the group name being varlously rendered as Chiaguan, Sciaguan, Siaban, Siguan, Tziaban, Xhiahuan and Zhiaguan (Valero Registers).

Only one cultural detail has been recorded for the Siaguan: the use of pricklypear fruit as food (Maas 1915:23-24). Mazanet's observations on languages spoken in southern Texas suggest that the Siaguan spoke a dialect of Coahuilteco (Gómez Canedo 1968:240).

Hodge $(1910, I I: 111,563)$ has given "Ohaguames" and "Siaguan" as names of two separate Indian groups, and in this he was followed by Swanton (1940:134-135) and Ruecking $(1955 \mathrm{a}: 329,365)$. It is now known that "Ohaguames" is a misreading of "Chaguames." "Mahuames" is listed by Hodge (1907, I:805; 1910, II:1085) as a synonym for "Mariames," but again "Mahuames" is a misreading of "Chahuames."

Siausi. One "Siausf" individual, a two-year-old girl, possibly an orphan, was baptized at San Francisco Solano in 1707, when the mission was at San Ildefonso (Solano Registers). This is one of 10 similar ethnic names which, without much question, all refer to the same group: Ciaefier, Ciaesier, Haeser, Saesse, Slaexe, Saeser, Siansi, Siausi and Xaeser. As considerable confusion surrounds these names, it is here suggested that Saesse be selected as the standard name for future use because it occurs in the earliest document (1675) and better represents the central orthographic tendency. The confusion arises from the fact that Hodge has presented "Haeser" and "Siansi" as names of two different groups (Hodge 1907, I:519; 1910, II:564). This error has never been corrected (see Branda 1976:367,878; Ruecking 1954a:7,21; 1955a:274,359,363,365; Swanton 1940:134,135).

Such records as have been found indicate that between the years 1675 and 1708 the Saesse (Siausi) ranged both sides of the Rio Grande between Eagle Pass and Del Rio, Texas, the area extending from the Coahuila mountain front northeastward across the Rio Grande at least as far as the southern margin of the Edwards Plateau of Texas (Alessio Robles 1938:232; Bolton 1916:299; Maas 1915:36-37). This would place the Saesse generally west, northwest, and north of the Guerrero mission center. 
Hodge $(1910,11: 426,546)$ and Santos (1966-1967:158) have reported "Siansi" and "Siausi" individuals at Mission San Antonio de Valero of San Antonio. This is in error. "Siansi" is a misreading of "Siausi," which occurs only in the records of San Francisco Solano.

Sijame. The name sijame has been recorded in at least 25 different ways, including Ciajame, Cijame, Hihame, Injame, Jijame, Scijame, Scipxame, Sicame, Sicxacama, Sixama, Syame, Tziame, Xixame and Zixame. The census of 1772 for Mission San Juan Bautista (Rodríguez 1772b:123) identifies one "Sixama," an adult male, married to a "Messca1," but this group is known to have been at other missions of northeastern Coahuila west of Guerrero. At El Nombre de Jesús de Peyotes, near present Villa Uniön, Coahuila, 76 "Sixames" were reported in 1734 (Zelis 1734:8-9). This mission had been founded in 1698. When San Francisco Vizarrón was founded nearby in 1737 , Sijame were present, and the same missionary report renders the name as both "Sijames" and "Hijames." It is said that the name means pescado, Spanish for "fish that have been caught for food" (Anónimo 1778:202-203; Morfi 1856:433-434).

The names Sijame and Hijame, noted above, have led to some confusion. Hodge (1907, I:549; 1910, I1:569-570) ambiguously refers to Sijame and Hihame as representing two separate groups and also designates the two names as synonymous. Swanton (1940:134,136) later 1isted them as separate groups, but Ruecking (1955a: 367-368) regarded the two names as synonymous.

The available information seems to indicate that the pre-mission Sijame territorial range was along the Coahulla mountain front west of Guerrero (Orozco y Berra 1864:302-303). Some Sijame who chose not to enter. missions in northeastern Coahuila, along with other local groups, migrated northeastward, and between the years 1709 and 1716 were reported in the area that extends from San Antonio northeastward to the lower San Gabriel River in Texas (Shelby 1923:176177; Tous 1930a:16-17; 1930b:5). It is this secondary location which has led to the suggestion that the Sijame may have spoken a Tonkawan language (Hodge 1910,11:569-570; Swanton 1940:136), which no longer seems plausible. After 1716 some of these Sijame migrants entered Mission San Antonio de Valero at San Antonio, whose records permit identification of at least 39 Sijame individuals between the years 1719 and 1763 (Valero Registers).

Tejas:- Three "Teja" individuals, a man and his two children (his wife is not ethnically identified), are recorded in the 1734 census report for San Juan Bautista (Garza Falcón 1734b:15). "Tejas" is an alternate name for the Hasinai, a Caddoan-speaking assemblage of central eastern Texas (Griffith 1951; Swanton 1942). As Guerrero was at the time on the main route of travel from Coahuila to the Spanish missions and settlements of eastern Texas, this family probably came to San Juan Bautista with Spaniards returning from that area. They may have gone back to their home territory shortly after this census was taken.

Tepehuan. Six Tepehuan can be identified in the baptismal register of San Francisco Solano for 1706-1707, when the mission was at San.I1defonso (Solano Registers). The group name is variously rendered as "Tepeguan," "Tepehuana" 
and "Tequeguan." Included are one adult male, three adult females, and two female children, ages two and six years. One of the children has a personal name that is probably of Indian origin, Guaparamana. Spouses are listed as "Mauyga" (or "Manyga"), "Mescal," and "Quesal" (Gueiquesal). The Tepehuan originally lived in Durango, but after their first major revolt in 1616-1618 (Bancroft 1884, I:319-329; Dunne 1936; Saravia 1937), some of them moved northeas tward into Coahuila and Nuevo León, where they were noted as early as 1626 (Cavazos Garza 1966a:190,199,276-277). The Tepehuan of San Francisco Solano were probably a small remnant that survived later rebellions in the Bolson de Mapimí area (Griffen 1969:passim).

Terocodame. In various documents the Terocodame are referred to by at least 25 similar names, of which the following are representative: Hierquodame, Hyroquodame, Hyroquodame, Iedocodame, Perocodame, Teocodame, Teodoran, Terrodan, Texocodame, Thezoccodame, and Toxocodame. The ir original territory is difficult to define but appears to have been a fairly large area on both sides of the Rio Grande north, west, and southwest of present Eagle Pass, Texas (Bolton 1916:288,299-300; Figueroa Torres 1963:118-119; Griffen 1969:38-39, $56,59-61,89,95,97,166)$.

The earliest reference to the Terocodame seems to have been under the name "Teodoran" in 1675 (Bolton 1916:299-301). The Bosque-Larios expedition of that year encountered them, along wi th "Xoman" (Jumano), "Teaname," and "Teimamar" (Tumamar), some 25 miles north of the Rio Grande, apparently somewhere north of present Eagle Pass, Texas. The four groups were encamped near a stream referred to by unspecified Indians as Ona, which they said meant "salty." The Spaniards made a head count of the total population, which was 1172 ( 425 males and 747 women and children). A few cultural details were recorded in connection with gifts which the Indians gave to the Spaniards: pieces of tallow and hides (animals not specified, but the Spaniards reported bison as numerous in the vicinity). The hides were said to have been used by the Indians for clothing and bedding.

In 1688 and again in 1694, Terocodame were mentioned in documents concerning Indian rebellions of central Coahuila that were put down by Spanish soldiers (Griffen 1969:38-39,95). Missionary reports of 1.701 indicate an expectation that the 1arge (mui crecida) Terocodame group would enter San Juan Bautista, but this did not happen (Sarmiento 1701:72; Weddle 1968:46-47). Instead they eventually entered Mission San Francisco Solano after it was moved from Guerrero to its San Ildefonso location near modern Zaragoza, Coahuila.

At least 73 individuals can be identified as "Terocodame" or "Theroquodame" in the baptismal register of San Francisco Solano. All except five of these were recorded for the years 1706-1708, when the mission was at San IIdefonso. The remaining five were recorded for the year 1712, when the mission was at San José. Of the 73 persons, 30 are adult males, 15 are adult females, and 28 are children (16 male, 12 female, ages ranging from 4 months to 8 years). Most personal names are Spanish, but a few seem to be of native origin: male-Cocossi, Gaguimo, Manomo, Taramo; female--Vidguadan. Spouses are identified as "Bobor" (Babor), "Cucusa," "Gavilan" (Gavilán), "Hicaragrande" (Jícaragrande), "Juman" (Jumano), "Manos Prietas," "Matuimi," "Maubedan," "Mauyga" (or "Manyga"), other "Terocodame" (five cases), "Ticmamar" (Tumamar), "Tuteneiboica," "Vidda- 
quimamar," and "Xarame" (Solano Registers). Most of the groups named on this spouse list are of western origin, that is, from Coahuila west of the Guerrero area, and were not represented at either San Juan Bautista or San Bernardo.

In 1718 San Francisco Solano was moved from its San José location to San Antonio, where it became known as Mission San Antonio de Valero. Very few Terocodame followed the mission to its new location. Only four Terocodame individuals can be found in the Valero registers: one adult male, two adult females, and one male child (1719-1732). Santos (1966-1967:158) has reported 23 "Texocodame" at San Antonio de Valero, but inspection of the records does not confirm this. The Valero records were evidently confused with those of San Francisco Solano.

After San Francisco Solano moved from its San Ildefonso location, most of the Terocodame there may have moved southward to enter Mission Santa Rosa de Nadadores northwest of Monclova. In documents of 1714-1722, the Terocodame of Nadadores were sometimes mentioned in reports of minor raids and rebe]1ions in central and western Coahuila (Griffen 1969:56,59-61,65-66,97-98). It is probably the Terocodame of Nadadores who are referred to in documents of 1724-1728, 1762, and 1767 as being among the Indian groups still present at Coahuila missions (Kinnaird 1958:154; Portillo 1886:251; Rivera y Villalón 1945:131). The Terocodame seem to have been last reported in a document of 1786, which indicates that sometime before that date the Indians at Nadadores had revolted and few had returned. After that the few Terocodame survivors were probably absorbed by the Mescalero and other Apache groups that had moved into northern Coahuila.

Swanton (1940:5,54-55) has published a 1 ist of 21 words "from a dialect spoken near the Mission San Francisco Solano" and said to have been recorded between 1703 and 1708 . This list had been discovered by H. E. Bolton. Nothing is said about which Indian group or groups spoke the dialect represented, which Swanton recognized as being different from Coahuilteco as recorded by Garcia (1760). Goddard (ms.) has recently examined the manuscript of Swanton's publication and reports that it contains an insert that was not published. According to this insert, Bolton had found the word list near the end of the baptismal register of San Francisco Solano and regarded it as a sample of Terocodame speech. No reasons for this judgment appear in the insert. A point at issue here is the fact that two Indian groups were numerically dominant at San Ildefonso, where the word list was probably assembled. These were the Terocodame and the Xarame, and of the two the latter outnumbered the former. Bolton's basis for selecting the Terocodame may never be known, but I am inclined to agree with his selection for the following reason. The Xarame were a more easterly group and were already known to the missionaries who worked at San Francisco Solano, whereas the Terocodame and their associates were new. The Terocodame dialect or language, which Goddard now refers to as the Solano dialect, was more likely to have been recorded by the missionaries.

Tilijae. The name Tilijae is known by at least 45 recognizable orthographic variants, among them Alijae, FiTixaye, Teloja; Thiloja. Tilofaya, Titijay, and Tolujaa. In 1708 Espinosa (Maas 1915:33) wrote that about 60 "Titijayas" had recently entered Mission San Juan Bautista but that most of them were 
away at the time of writing. In 1727 Sevillano de Paredes (1727:42-43) identified the "Filijayes" as one of the three most numerous groups represented at San Juan Bautista, the total Indian population at the mission then being about 240. These Tilijae must have left the mission during the next few years because the mission census of 1734 (Garza Falcon 1734b:16) recorded onity one adult male "Tilihay." Some had returned by 1738 , when 37 "Tilijayas" were reported (Portil10 1886:283). Thereafter the Tilijae seem to have left San Juan Bautista for good. One individual is mentioned in a document of 1754 (Guadalupe 1754:178), but the census of 1772 reported no Tilijae.

The Tilijae who abandoned San Juan Bautista may have gone to other missions. Some "Tilijai" were at San Francisco Vizarrón shortly after its foundation in 1737 near present Villa Unión, Coahuila, west. of Guerrero (Guadalupe 1754:178). Others entered missions at San Antonjo, Texas, after 1731. In the marriage. register of Nuestra Señora de la Purisima Concepción de Acuña one "Tiloja" is recorded for 1733 (Concepción Marriage Register), and "Thelojas" were said to be present at this mission in 1743 (Santa Ana 1743:69). At least 20 "Thelojas" were present at Mission San Juan Capistrano in 1737 (Habig 1968:164).

In 1675, before permanent missions were established in the area, the Tilijae apparently ranged mainly over northeastern Coahuila, particularly in the more easterly section (Bolton 1916:304). "Tilalajais" were at Mission San Bernardino de la Candela of eastern Coahuila at or shortly after its foundation in 1690 (Alessio Robles 1938:272,385-386). After 1700, however, Tilijae were reported north of the Rio Grande in southern Texas, especially in the Nueces River valley east of the Guerrero missions. In 1727 Sevillano de Paredes (1727:43) estimated that 300 "Tilixes" were living along the Nueces River below the Pampopa.

Garcia (1760:title page) identified "Tilijayas" as one of the mission groups that spoke dialects of Coahuilteco.

Tlascalteco. One "Tlascalteca" male, Pedro de la Cruz, was identified as the godfather of a Terocodame child baptized at San Francisco Solano in 1712, when this mission was located at San José (Solano Registers). The Tlascaltecans, a Nahuat1-speaking group of southern Mexico (east of Mexico City), aided Cortez in the conquest of Mexico and thereafter had a most-favored status among the Indians of Mexico. They were used by Spaniards in exploration, warfare, and colonizing (Gibson 1953; Simmons 1964). Christianized Tlascaltecan families were sometimes settled at newly founded missions of northeastern Mexico to serve as models for the hunting and gathering Indians.

Toboso. One Toboso female, said to be 80 years of age, was recorded at San Francisco Solano in 1706, when the mission was at San I1defonso (Solano Registers). Griffen's (1969:73-103) studies indicate that the original Toboso territory was probably in southeastern Chihuahua, but that by the middle seventeenth century they had been displaced and were ranging widely over the Bolsón de Mapimí area of eastern Chihuahua and western Coahuila. They were greatly reduced in Spanish-Indian wars, and by the latter part of the century not very many were left. The name Toboso was at times loosely used by Spaniards to refer 
to the Toboso and other closely associated refugee groups of the Bolson de Mapimi desert. As the Toboso were traditionally hostile to Spaniards, very few of them entered missions anywhere. The elderly female at San Francisco Solano may have been a captive or the sole survivor of one of the small refugee groups. Griffen (1969:142) has discredited the belief, long held, that the Toboso were either Apache or pre-Apache Athapaskan speakers.

Tripas Blancas. For the period 1706-1708, when Mission San Francisco Solano was at San Ildefonso, 20 Tripas Blancas (Spanish for "white bellies") are recorded in the baptismal register. Included are 5 adult males, 2 adult females, and 13 children (10 males, 3 females, ages 5 months to 7 years). Except for one "Vitdemamar" (Viddaquimamar), a 71 spouses are 7 isted as other "Tripas Blancas" (Solano Registers). The presence of Tripas Blancas at San Francisco Solano is also confirmed by Espinosa (Maas 1915:35) and by San Buenaventura y Salazar (1708:25). The pre-mission territorial range of the Tripas Blancas cannot be clearly specified, but records of participation in raids and rebellions suggest a western location, possibly central Coahuila (Alessio Robles 1938:417-418,550; Bolton 1913:423; Griffen 1969:54,60,103,168; Hodge 1910, II:819; Wheat 1957, I :Map No. 115).

Tumamar. This name occurs in about 30 different forms, among which are Feimama, Ja imamar, Lumamar, Ta imamar, Tasmamar, Teimamar, Ticmamar, Timama, Trasmama, Tuimamar, and Tunmamar. Some variants are obviously the product of bad handwriting. In Hodge (1910,II:672,837) there are separate entries for "Taimamares" and "Tumamar," but in the synonymy section the two are consistently equated.

The pre-mission territory of the Tumamar is not easily defined but seems to have been a large area in northern Coahuila and the closely adjoining part of Texas just north of the Rio Grande, all of it west and northwest of the Guerrero mission center (Alessio Robles 1938:232,255; Bolton 1911:79;1916:299; Figueroa Torres 1963:77,118; Griffen 1969:xi i,93-93).

In the baptismal register of Mission San Francisco Solano, 20 individuals are identified as "Ticmamar," "Trimamar," and "Tumamar." Included are 7 adult males, 6 adult females, and 7 children ( 4 male, 3 female, ages 1 to 6 years). Eighteen were baptized at San Ildefonso (1706-1707) and two at San José (1713). Spouses are listed as "Gabilan," "Terocodame," and other "Ticmamar." The personal name of one female, rendered in two ways, is probably of Indian origin: Jurgaquadan, Terguejuadan (Solano Registers).

One "Tumamar" is recorded in the census of 1734 taken at San Juan Bautista (Garza Falcón 1734b:15). Some of the Tumamar migrated northeastward after 1700 and lived at the refugee encampment known as Ranchería Grande, near the junction of the Little and Brazos Rivers of east-central Texas (Hodge 1910,II: 354). Some of these migrants eventually entered Mission San Antonio de Valero at San Antonio, in the registers of which at least 15 "Tumamar" are identifiable after 1722. In various entries one individual is identified as "Tamamare," "Ticmama," and "Timamar" (Solano Registers). 
Tusan. In 1762 Ximénes (1962b:106) reported that some Tusan had arrived at Mission San Juan Bautista in the preceding year, and he expressed disappointment over the fact that only five individuals had agreed to receive religious instruction. In copies of the Ximenes report, the name Tusan was misread as "Juran" and "Turan." Ximenes also stated that these Tusan had come from the east and that they were also known by another name, Carrizo. During the second half of the eighteenth century, the name Carrizo was often used collectively to refer to remnants of various Indian groups living along both sides of the Rio Grande between Laredo and the Gulf coast. At times the name was used to refer to both Comecrudo and Cotoname, possibly because in that area carrizo (Spanish for "cane") was commonly used in Indian house construction (Gatschet 1891:38; Kress and Hatcher 1931:35; Wheat 1957, I:Maps. No. 115,149; Wilcox 1946:349, 355-356).

The name Tusan appears only in documents pertaining to San Juan Bautista and was probably the native name for one of the more westerly "Carrizo" groups. The name "Tuisoni," which identifies an adult female in the San Juan Bautista census report of 1772 (Rodríguez 1772b:197), is evidently a variant of Tusan.

Hodge $(1910, \mathrm{II}: 841,854)$ has distinguished between "Tusanes" and "Tusonid," but these are now best regarded as names for the same Indian group. The sources cited by Hodge indicate that both names originated at San Juan Bautista during the period 1762-1772, and his "Tusonid" is probab7y the same as "Tuisoni" of the 1772 census report. Hodge's distinction between Tusanes and Tusonid was followed by both Swanton (1940:136) and Ruecking (1955a:384).

Some of the figures given for the Tusan population at San Juan Bautista are erroneous. Hodge (1910,II:841) refers to the presence of 213 "Tusanes" at San Juan Bautista in 1761. This figure refers not to the Tusan alone but to the entire mission Indian population of 1761 . Ruecking $(1955 \mathrm{a}: 18,384)$ cited Hodge's figure of 213 on one page but on another gave a figure of 102 .

The name Carrizo continued in use until the middle of the nineteenth century, when the assemblage of remnants known by that name lost its identity in northeastern Mexico and southern Texas (Berlandier 1969:51,62,85,165; Nance $1964: 233,470,540,552$; Winfrey and Day 1966, III :261-262). Goddard (ms .:3,15= $17,19)$ is currently making a study of "Carrizo" speech samples recorded in the nineteenth century.

Tuteneiboica. In the baptismal register of San Francisco Solano, two Tuteneiboica individuals are identified for the year 1706, when the mission was at San Ildefonso. The pair consists of a man and his one-year-old daughter; the wife is listed as "Terocodame" (Solano Registers). Hodge (1910, II $: 732,733,856)$ has an entry for the Tuteneiboica, but he also has a separate entry for a similar name, Tetanauoica, which cites a statement by Bolton that an Indian (apparently male) of that group was buried at San Francisco Solano in 1707. I have been unable to find this in the San Francisco Solano burial register, which may now have some entries missing. It is possible that Tuteneiboica and Tetanauoica are merely variants of the same group name and that the population originally lived in southern Coahuila. Griffen (1969: 
$167,172)$ found records of "Tetonbopoca" and "Tetenobapar" in Parras documents of 1636-1638.

Uracha. Documents pertaining to the Guerrero missions do not contain the name Uracha, but the baptismal register of Mission San Antonio de Valero at San Antonio identifies an Uracha (or Urache) family: man, wife, and newly born female child. This family is said to have formerly lived at San Juan Bautista on the Rio Grande. The entry date is 1765 (Valero Registers). Two similar ethnic group names occur in earlier documents: Uraca, southern Plains, about 1630 (Vetancurt 1971:96) and Orancho, western Edwards Plateau, 1684 (Bolton 1916:340). Scanty and unreliable information, as well as lengthy time gaps between the several documents, discourage further attempts to relate these recorded group names.

Viddaquimamar. Eleven Viddaquimamar (the name also rendered as "Biddaquimamar" and "Vitdemamar") are identified in the baptismal register of San Francisco Solano for the years 1706-1707, when the mission was at San IIdefonso (Solano Registers). Of these 11 individuals, 2 are adult males, 4 are adult females, and 5 are children ( 4 males, 1 female, with ages ranging from 3 months to 8 years). Two of the women are listed as married to "Terocodame" males and one to a "Pabor" (Babor). The Viddaquimamar seem to have been displaced from central Coahuila during the seventeenth century. They may also be recorded under such names as Biamoma, Biamomama, Bidamamara, and Bimama (Griffen 1969:90,156,174).

Xarame. In Spanish documents the Xarame are referred to by at least 25 similar names, and the range of variation is indicated by the following list: Arame, Charame, Charrom, Harane, Jalam, Jarame, Jurame, Sarame, Schiarame, Xalan, Xaram, Xharame, and Zarame. Xarame is sometimes confused with the name Aranama and its variants, which refer to a different ethnic group that ranged much farther to the east, near the Gulf Coast of Texas. The premission territorial range of the Xarame is not clearly defined, but such evidence as is available indicates an area that extended from the Río Sabinas of northeastern Coahuila northeastward across the Guerrero section of the Rio Grande to the Frio River southwest of San Antonio, Texas (Bolton 1916: 307-308; León y otros 1961:219; Tous 1930b:4).

Some Xarame were at Mission San Juan Bautista when it was first established on the Río Sabinas of northeastern Coahuila in 1699 (San Buenaventura y Salazar 1699:45) but few of these seem to have followed the mission when it was moved to Guerrero in 1701 (Morfi 1856:440-441). No Xarame were counted in the San Juan Bautista census of 1734 , but three "Jalam" were identified in the census of 1772 (Rodríguez 1772b:127): a man and his two daughters. Only two Xarame are recorded for Mission San Bernardo, an adult male "Jalan" in 1734 (Garza Falcón 1734a:22), and an adult female "Jalam" in 1772 (Rodríguez 1772a:65).

It was to San Francisco Solano that the Xarame went in considerable numbers.; and its registers indicate the presence of at least 98 individuals: 44 aduit 
males, 34 adult females, and 20 children ( 9 male and 11 female). Of these 98 persons, 25 can be associated with San Francisco Solano at its Guerrero location, 21 at its San Ildefonso location, and 52 at its San José location (Solano Registers). In most entries the group name is given as "Xarame," but in a few entries it is given as either "Xaram" or "Jarame." Spouses are identified as "Jape" (Hape), "Mesquite o Lagaun," "Papanac," "Paquache" (Pacuache), "Pataguan" (Pataguo), "Payuguan," "Siaban" (Siaguan), "Theroquodame" (Terocodame), "Thimamar" (Tumamar), and other "Xarame" (21 cases).

When San Francisco Solano was moved to San Antonio in 1718 and was renamed San Antonio de Valero, many Xarame transferred to the new mission location. In the registers of Mission San Antonio de Valero, 155 Xarame can be traced through the remainder of the century (Valero Registers). It is thus evident that the Xarame preferred Mission San Francisco Solano and were present in considerable numbers at all four of its successive locations.

Yorica. The name Yorica, often misread, occurs in at least 13 forms, among which are Corica, Giorica, Giorna, Gorica, Goxica, Hiorna, Lorica, Orica, Torica, and Yoxica. In documents which date from 1674 to 1691, the Yorica are repeatedly identified with the area that extends from the Rio Sabinas of northeastern Coahuila northward across the Eagle Pass-Guerrero section of the Rio Grande to the southern margin of the Edwards Plateau in Texas (Bolton 1916: 296-297,307-308,356; Figueroa Torres 1964:104; Gómez Canedo 1968:8-9,160,232, 306; Steck 1935:14-15).

The Yorica were listed among the groups at San Juan Bautista when it was initially established on the Río Sabinas in 1699 (Espinosa 1964:753), and they were also identified as being at San Juan Bautista after it had been moved to Guerrero in 1700 (Maas 1915:18,30,33). The censuses taken at San Juan Bautista, however, include no Yorica individuals. In 1704, one Yorica, an adult female, was recorded in the registers of San Francisco Solano when it was still located at Guerrero (Solano Registers). At least three Yorica can be identified in the records of San Antonio de Valero at San Antonio (1723-1730), and one of these is said to have come from Mission San Juan Bautista on the Rio Grande (Valero Registers). As so few Yorica individuals were recorded at the various missions, they may have rapidly declined in numbers before 1700, perhaps as the result of epidemics sometimes mentioned by advance missionaries of 16741675 (Steck 1932:15).

A few features of Yorica culture can be assembled, mainly from documents of 1674-1675. The Yorica are said to have had no horticulture and moved about in search of animal and plant foods. Deer and bison were hunted for meat and hides. Bison meat was sometimes dried at the scene of the kill and transported on human backs to encampments, occasionally at considerable distances. Two important plant foods were maguey root crowns and fruit of the prickly pear. The bow and arrow was used in hunting and warfare. The Yorica took boy captives, ate enemy flesh on occasion, and had "peace" ceremonies that involved body painting, dancing, and exchange of bows and arrows (Bolton 1916:296, 307-308; Figueroa Torres 1963:104,118-119; Hatcher 1932:50; Steck 1932:15). Mazanet's linguistic observations suggest that the Yorica spoke a dialect of Coahuil teco (Gómez Canedo 1968:240). 
Ruecking (1955a:274-275,399), who made use only of publ ished data, failed to note that "Giorna" is a variant of the name Yorica and lists the two as separate group names.

Yujan. In the census taken at Mission San Juan Bautista in 1772 (Rodriguez 1772b: $123,127,129$ ), three individuals, all adults (one male, two female) are identified as "Yujan" and "Yugana," the latter given for a female married to a "Pastaloco." Yujan and Yugana probably refer to the group given by Hodge (1907,I:574) as "Huanes," who were among the Indian groups that entered Mission San José y San Miguel de Aguayo of San Antonio, Texas, after 1731 (Forrestal 1931:20; Kress and Hatcher 1931:51). The Huane of Mission San José are also recorded various ly as Xamas, Xanas; Xauanaes, Xauanaos, and Xuanes. No documents have been found which indicate a pre-mission location, but circumstantial evidence suggests southern Texas, probably inland between San Antonio and the Rio Grande.

In 1684 Dominguez de Mendoza met or heard of "Juanas" when he was in the western part of the Edwards Plateau (Bo7ton 1916:339), but the evidence is not good enough to establish a relationship between these "Juanas" and the Huane of San José or the Yujan of San Juan Bautista. Although the name Yujan resembles Yojuane, the name of a group in eastern central Texas usually classified as a Tonkawan people, there is probably no connection. A few Yojuane were recorded at other missions in San Antonio (Valero and Concepción). but not at San José, whose Indian groups came mainly from southern Texas. 
TABLE 1. INDIAN GROUPS REPRESENTED AT GUERRERO MISSIONS

Population Figures Compiled from Registers and Censuses

San Francisco Solano

(Registers 1700-1718)

1

2

3 Apache: 7

4 Babor: 30

5 Bacorame: 8

\section{6}

7

8

9

10

11

12 Cenizo: 6

13

14 Coaxa: 1

15 Cohabita: 1

16 Colorados: 1

17 Cucusa: 10

18 Dedepo: present

19 Ervipiame: 3

20 Gavilán: 14

21 Guachichil: 1

22 Gueiquesal: 2

San Juan Bautista

(Censuses 1734,1772 )

Achoj: 0, 5

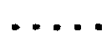

Apache: 1,0

Borrados: 0,2

Cabezas: 4,0

Cachopostal: 0,4

Campacuas: 0,14

Canua: 2,4

Catujan: 2, 5

Chapamo: 0,2

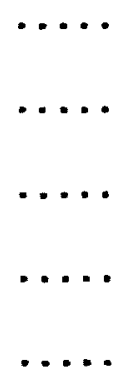

Ervipiame: 1, 0 
TABLE 1. (continued)

San Francisco Solano

(Registers 1700-1718)

23 Guerjuadan: 1

24 Hape: 1

25 Hume: 1

26

27 Jicaragrande: 3

28

29 Julime: 2

30 Jumano: 16

31 Macapao: 1

32 Macocoma: 1

33

34 Mamuqui : 1

(personal name)

35 Manico: 1

36 Manos Prietas: 1

37 Matuimi: 2

38 Maubedan: 2

39 Mauyga (or Manygua): 10

40

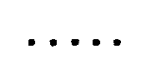

41 Mesca1: 5

42 Mesquite: 2

43 Muruame: 3

44 Ocana: 1
San Juan Bautis ta

(Censuses 1734, 1772)

Hape: present

Hume: present

Jacao: 5,8

Juanca: 1,1

Jumano: present

Malaguita: 0,10

Malaguita: 0,2

Manico: 5,4

- Maurb: 1,0

(personal name)

Mesca ]: 17,27

Ocana: 9,6 
TABLE 1. (continued)

San Francisco Solano

(Registers 1700-1718)

45

46 0ydican: 17

47

48

49

50

51 Pacuache: 2

52

53

54

55 Papanac: 3

56

57

58

59 Pataguo: 3

60 Patzau: 1

61

62 Pausaqui: 2

63 Payaya: 2

64 Payuguan: 9

65 Piedras Chiquitas: present

66 Piniquu: 1
San Juan Bautista

(Censuses 1734, 1772)
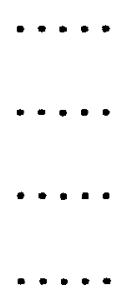

Pachana: 1,0

Pacoa: 0,11
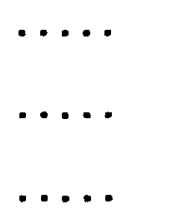

Pampopa: 6, 31

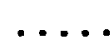

Pastaloca: 6, 20

Patacal: 0,14

Pataguo: 2, 0

Patzau: 0,3

Payaya: 1, 2

Payuguan: present
San Bernardo

(Censuses 1734, 1772)

ocora: 4,0

Paac: 3,5

Pachal: 21, 24

Pacoa: 6, 26

Pacuache: 5,85

Pamajo: 2, 0

Pamasu: present

Papanac: 5,3

Pastaloca: 15, 9

Pastancoya: 8,5

Patacal: 6, 13

Pataguo: 4, 0

Patzau: 3,0

Pausane: 2, 0

Payaya: 0,6

Payuguan: present 
TABLE 1. (continued)

San Francisco Solano

(Registers 1700-1718)

67

68

69

70

71

72 Siausi: 1

73

74 Siaguan: 24

75

76

77 Tepehuan: 6

78 Terocodame: 73

79

80 Tlascalteco: 1

81 Toboso: 1

82 Tripas Blancas: 20

83 Tumamar: 18

84

85 Tuteneiboica: 3

86

87 Viddaquimamar: 11

88 Xarame: 98

89 Yorica: 1
San Juan Bautista

San Bernardo

(Censuses 1734, 1772) (Censuses 1734, 1772)

Pita: 0,1

Pitahay: 4,0

Pitalac: 0,1

Pomulum: 1,1

Pomuzeno: 0,1

Samioj: 4,0

Siaguan: 1,0

Siaguan: 17,7

Sijame: 0,1

Tejas: 3,0

Tilijae: 1,0

Tumamar: 1,0

Tusan: 0,1

Uracha: present

Xarame: 0,3

Xarame: 1,1

Yorica: present 
TABLE 1. (continued)

San Francisco Sol ano

(Registers 1700-1718)

90

Totals 435
San Juan Bautista

(Censuses 1734, 1772)

Yujan: 0,3

46,156
San Bernardo

(Censuses 1734, 1772)

135,238 


\section{REFERENCES CITED}

Abbreviations used:

AGI Archivo General de Indias. Sevilla.

AGN Archivo General de la Nación. México.

BAN Boletín del Archivo de la Nación. México.

BAT Bexar-Archives Translations. Austin.

BTHCA Barker Texas History Center Archives. The University of Texas, Aus tin.

CIWP. Carnegie Institution of Washington, Publications. Washington, D.C.

NMHR New Mexico Historical Review. Santa Fe.

PITM Publicaciones del Instituto Tecnológico y de Estudios Superiores de Monterrey. Monterrey, Nuevo León.

PTCHS Preliminary Studies of the Texas Catholic Historical Society. Austin.

QSP Quivira Society Publications. Albuquerque and Berkeley.

QTSHA The Quarterly of the Texas State Historical Association. Austin.

SA Saltillo Archives. Saltillo, Coahuila.

SFGA San Francisco el Grande Archives (copy). The University of Texas, Austin.

SHQ - The Southwestern Historical quarterly. Austin.

SIBAE Smithsonian Institution, Bureau of American Ethnology, Bulletin. Washington, D.C. 
Alessio Robles, Vito

1936 Monterrey en la Historia y en la Leyenda. México.

1938 Coahuila y Texas en la Época Colonial. México.

Anónimo

1778 Descricion del Territorio del Precidio de San Juan Bautista de Rio Grande de1 Norte. AGN, Historia 29 (BTHCA, 2Q178, Vo1. 348:185-204).

Ayer, Mrs. Edward E., translator

1916 The Memorial of Fray Alonso de Benavides, 1630. Annotated by Frederick Webb Hodge and Charles Fletcher Lummis. Chicago.

Bancroft, Hubert Howe

1883 The Works of Hubert Howe Bancroft. Vol. I, Wild Tribes. San Francisco.

1884 The Works of Hubert Howe Bancroft. Vol. XV, History of the North Mexican States and Texas, 1531-1800. Vol. I. San Francisco.

Benson, Nettie Lee, translator and editor

1950 Report that Dr. Miguel Ramos de Arizpe... Presents to the August Congress on the Natural, Political and Civil Conditions of the Provinces of Coahuila, Nuevo Leon, New Mexico, Nuevo Santander, and Texas .: . University of Texas Press, Austin.

Berlandier, Jean Louis

1969 The Indians of Texas in 1830. Edited and introduced by John C. Ewers. Smithsonian Institution Press, Washington, D.C.

ms. Journey to Mexico during the Years 1826 to 1874. Translated by Sheila Ohlendorf.

Bolton, Herbert E.

1907 Spanish Mission Records at San Antonio. 2TSHA 10(4):297-307.

1911 The Jumano Indians of Texas, 1650-1771. 2TSHA 15(1):66-85.

1912 The Spanish Occupation of Texas, 1519-1690. SH2 16(1):1-26.

1913 Guide to Materials for the History of the United States in the Principal Archives of Mexico. CIWP 163. 
Bolton, Herbert E.

1914 The Founding of the Missions on the San Gabriel River, 1745-1749. SHQ 17(4):323-378.

1915 Texas in the Middle Eighteenth Century. Studies in Spanish Colonial History and Administration, University of California Publications in History, III. Berkeley.

1916 Spanish Exploration in the Southwest, 1542-1706. New York.

Branda, Eldon Stephen, editor

1976 The Handbook of Texas: A Supplement. The Texas State Historical Association, Austin.

Cabe110, Domingo

1780a Expediente. Cabello submits his report concerning activities of some citizens of Nuevo Santander who buy and sell Indians. BAT 96:33-39.

1780 b Letter Number 241, Cabel10 to de Croix. BAT 98:78-79. Campbe11, T. N.

1975 The Payaya Indians of Southern Texas. Southern Texas Archaeological Association, Special Publication 1. San Antonio.

1977 Ethnic Identities of Extinct Coahuiltecan Populations: Case of the Juanca Indians. Texas Memorial Museum, The Pearce-Sellards Series 26. Austin.

Castañeda, Carios E.

1936 Our Catholic Heritage in Texas, 1519-1936. Vo1. I, The Mission Era: The Founding of Texas, 1519-1693. Austin.

1938 Our Catholic Heritage in Texas, 1519-1936. Vo1. III, The Mission Era: The Missions at Work, 1731-1761. Austin.

Cavazos Garza, Israel

1964 Cedulario Autobiográfico de Pobladores y Conquistadores de Nuevo León. Biblioteca de Nuevo. León 2. Monterrey, Nuevo León.

1966a Catalogo y Síntesis de los Protocolos del Archivo Municipal de Monterrey, 1599-1700. PITM, Serie: Historia 4.

1966b El Municipio de Santa Catarina en la Historia. Humanitas: Anuario del Centro de Estudios Humanisticas, Universidad de Nuevo León 7:301-311. Monterrey, Nuevo León. 
Concepción Marriage Register

ms. This register is in the San Fernando Archives, San Antonio, Texas (see Santos 1966-1967). Photostat and microfilm copies in the Texas Cathol ic Archives, Austin.

Cuervo y Vaidés, Francisco

1698 Carta al Rey, Moncloba, 26 de Agosto de 1698. AGI, Audiencia de Guadalajara (BTHCA, 2Q145, Vo1. 72:5-7).

1699 Fundazion del Pueblo y Mision del Nombre de Jesus en el Nuebo Balle de San Bartolome de Yndios Gentiles de las naziones Chantafs, Pacco, y Payaguas. AGI, Audiencia de Guadalajara (BTHCA, 2Q136, Vo1. 17:225-236).

1700a Carta del Gobernador Don Francisco Cuervo de Valdes a S. M. fha. en Santiago de la Moncloba a 23 de Junio de 1700. AGI, Audiencia de Guadalajara (BTHCA, 2Q136, Vol. 20:10-17).

1700b: Fundacion del Pueblo y Mision de San Francisco Solano en el Nuebo Valle de la Zircunzision de Yndios Gentiles de las naciones Sarames, Papanac, Payaguan, y Siaguan. AGN, Provincias Internas 28 (BTHCA, 2Q203, VoT. 466:22-29).

1701 Testimonio de 1a Fundacion de San Juan año de 1701. AGN, Historia 29 (BTHCA, 2Q178, Vo1. 348:5-16).

Dabbs, J. Autrey

1940 The Texas Missions in 1785. PTCHS 3(6).

De Villiers du Terrage et $P$. Rivet

1919 Les Indiens du Texas et les Expéditions Françaises de 1720 et 1721 a la "Baie Saint-Bernard." Journal de la Société des Americanistes de Päris, Nouveile Série; Tome XI:405-442:

Dolores, Mariano Francisco de los

1750 Padrones de las Misiones del Rio San Xavier (de la Provincia de Texas) en 13 de Enero de 1750. SFGA (BTHCA, 2Q249, Vol. 5: 47-55).

1762a Informe rendido por los Ministros de las Misiones de el Rio de San Antonio a Fr. Francisco Xavier Ortiz. SFGA (BTHCA, 2Q256, Vol. 835:38-76).

1762b Fray Mariano de los Dolores...a Fray Francisco Xavier Ortiz, 6 de Marzo, 1762. AGN, Historia 28 (BTHCA, 2Q177, Vol. 347: 162-183). 
Driver, Harold E. and William C. Massey

1957 Comparative Studies of North American Indians. Transactions of the American Philosophical Society 47(2):165-456. Philadelphia.

Dunne, Peter M.

1936 The Tepehuan Revolt. Mid-America 18(1):3-14.

Durán, Miguel

1744 Descripcion y Mapa de la Nueva Provincia poblada de Barbaros que en la America Septentrional... (BTHCA: map collection).

Escandón, Joseph de

1751 Quaderno de las 18 Poblaziones fechas por el General Don Joseph de Escandón que en cada una de ellas se hall an avecindadas. AGN, Provincias Internas 180 (BTHCA, Transcripts, Vol: 420:1-373).

Espinosa, Isidro Félix de

1708 (untitled report on Coahuila missions). AGI, Audiencia de Mexico (BTHCA, 2Q146, Vo1. 77:29-43).

1746 Chrônica Apostólica y Serâphica de todos los Colegios de Prapaganda Fide de esta Nueva-España, parte primera. México.

1964 Chróniea de los Calegios de Propaganda Fide de la Nueva España. Mexico 1746 . New edition with notes and introduction by Lino G. Canedo. Academy of American Franciscan History, Washington, D.C.

Esteves, Francisco

1699 Misiones de Coahuila. AGI, Audiencia de México (BTHCA, 2Q145, Vol. 72:39-41).

Figueroa Torres, 3 , Jesus

1963 Fr. Juan Larios: Defensor de las Indios y Fundador de Coahuila, 1673-1676. México.

Foik, Paul J.

1933 Captain Don Domingo Ramón's Diary of His Expedition into Texas in 1716 . PTCHS 2(5).

Forbes, Jack D.

1957 The Janos, Jocomes, Mansos and Sumas Indians. NMHR 32:319-334. 
Forbes, Jack D.

1959 Unknown Athapaskans: The Identification of the Jano, Jocome, Jumano, Suma, and Other Indian Tribes of the Southwest. Ethnohistory 6(2):97-159. B Toomington.

1960 Apache, Navaho and Spaniard. University of Oklahoma Press, Norman.

Forrestal, Peter P.

1931 The Solis Diary of 1767. PTCHS 1(6).

1935 Peña's Diary of the Aguayo Expedition. PTCHS 2(7).

1954 Benavides' Memorial of 1630. Publication of the Academy of American Franciscan History, Documentary Series 2.

García, Bartholomé

1760 Manual para Administrar los Santos Sacramentos de Penitencia, Eucharistia, Extrema-uncion, y Matrimonio... México.

Garza Falcón, Blas de la

1734a Pueblo y Micion de S. Bernardo de el Rio Grande de el Norte. AGI, Audiencia de México (BTHCA, 2Q147, Vol. 84:19-24).

1734b Yndios de la Micion. AGI, Audiencia de México (BTHCA, 2Q147, Vol. $84: 15-19$.

Gatschet, Albert S.

1891 The Karankawa Indians, The Coast People of Texas. Archaeological and Ethnological Papers of the Peabody Museum, Harvard University 1(2). Cambridge.

Gibson, Charles

1952 Tlaxcala in the Sixteenth Century. Yale History Publications, Miscellany 56. New Haven.

Gilmore, Kathleen Kirk

1969 The San Xavier Missions: A Study in Historical Site Identification. State Building Commission, Archaeological Program, Report 16. Austin.

Goddard, Ives

ms. The Languages of South Texas and the Lower Rio Grande. 
66.

Gómez Canedo, Lino

1968 Primeras Exploraciones y Poblamiento de Texas (1686-1694). PITM, Serie: Historia 6.

González, José Eleuterio

1885 Colección de Noticias y Documentos para la Historia del Estado de Nuevo León. Monterrey.

1887 Apuntes para la Historia Eclesiastica de las Provincias que formaron el obispado de Linares, Monterrey.

Gould, Frank W.

1962 Texas Plants, A Checklist and Ecological Summary. Texas Agricultural Experiment Station, MP-585. College Station.

Griffen, William B.

1969 Culture Change and Shifting Populations in Central Northern Mexico. Anthropological Papers of the University of Arizona 13. Tucson.

Griffith, William Joyce

1954 The Hasinai Indians of Texas as Seen by Europeans, 1687-1772. Philological and Documentary Studies, Tulane University 2(3). New Orleans.

Guada lupe, Joseph

1754 Querella de San Juan Capistrano por los Agravios y Daños que le Causa Vizarron. Archivo de Colegio de Santa Cruz de Queretaro, KN 15 (BTHCA, 2Q237, Vo1. 768:172-183).

Gursky, Karl-Heinz

1964 The Linguistic Position of the Quinigua Indians. International Journal of American Linguistics 30(4):325-327. Baltimore.

Habig, Marion A.

1968 The Alamo Chain of Missions: A History of San Antonio's Five oed Missions. Franciscan Herald Press, Chicago.

Hackett, Charles Wilson, editor

1926 Historical Documents Relating to New Mexico, Nueva Vizcaya, and Approaches Thereto, to 1773. CIWP 330 (two volumes). 
Hackett, Charles Wilson, editor

1931 Pichardo's Treatise on the Limits of Louisiana and Texas, Vol. 1. University of Texas Press, Austin.

Hatcher, Mattie Austin

1932 The Expedition of Don Domingo Terán de los Ríos into Texas. PTCHS 2(1).

Hester, Thomas R. and T. C. Hill, Jr.

1975 Some Aspects of Late Prehistoric and Protohistoric Archaeology in Southern Texas. Center for Archaeological Research. The University of Texas at San Antonio, Special Report 1. San Antonio.

Hodge, Frederick Webb

1907, Handbook of American Indians North of Mexico. STBAE 30 1910 (two volumes).

1910 The Jumano Indians. Proceedings of the American Association for the Advancement of Science, n.s. 10:249-268.

Hodge, Frederick Webb, George P. Hammond, and Agapito Rey

1945 Fray Alonso de Benavides' Revised Memorial of 1634. Coronado Cuarto Centennial Publication, 1540-1940 IV. University of New Mexico Press, Albuquerque.

Hoffmann, Fritz Leo (translator)

1935 Diary of the Alarcón Expedition into Texas, 1718-1719, by Fray Francisco Céliz. Quivira Society Publications 5. Los Angeles.

1938 The Mezquía Diary of the A7arcón Expedition into Texas, 1718. SH2 41(4):312-323.

Hoyo, Eugenio de 1

1960 Vocablos de la Lengua Quinigua de Tos Indios Borrados del Nores te de Mexico. Humanitas 1(1):489-515. Universidad de Nuevo León, Monterrey.

1963 Indice del Ramo de Causas Criminales del Archivo Municipal de Monterrey (1621-1834). PITM, Serie: Historia 2.

1972 Historia del Nuevo Reino de León (1577-1723). PITM Serie: Historia 13. 
Jiménez Moreno, Wigberto

1944 Tribus e Idiomas del Norte de México. El Norte de México y el Sur de Estados Unidos. Tercera Reunión de Mesa Redonda sobre Problemas Antropologicos de México y Centro América, Sociedad Mexicana de Antropología:121-133. México.

1958 Estudios de Historia Colonial. Instituto Nacional de Antropologia e Historia, Serie Historica. Mexico.

Johnson, Frederick

1940 The Linguistic Map of Mexico and Central America. In: The Maya and Their Neighbors:88-114. New York.

Kelley, J. Charles

1952- The Historic Pueblos of La Junta de los Rios. NMHR 27(4):

$1953 \quad 257-296 ; 28(1): 21-51$.

1955 Juan Sabeata and Diffusion in Aboriginal Texas. American Anthropologist 57(5):981-995. Menasha.

Kinnaird, Lawrence

1958 The Frontiers of New Spain: Nicolas de Lafora's Description, 1766-1767, Quivira Society Publications 13. Berkeley.

Kress, Margaret Kinney, and Mattie Austin Hatcher

1931 Diary of a Visit of Inspection of the Texas Missions Made by Fray Gaspar José de Solís in the Year 1767-1768. SHQ 35(1): 28-76.

Krieger, Alex D.

1961 The Travels of Alvar Nuñez Cabeza de Vaca in Texas and Mexico, 1534-1536. In: Homenaje a Pablo Martinez del Río.en el XXV Aniversario de la Edición de Los Orígenes Americanos: 459474. México.

Lafora, Nicolas de

1939 Relación del Viaje que hizo a los Presidios Internas situados en la Frontera de la América Septentrional perteneciente al Rey de España, con un Liminar Bibliográfico y Acotaciones por Vito Alessio Robles. México. 
Leön, Alonzo, Juan Bautista Chapa y el Gral. Fernando Sánchez de Zamora 1961 Historia de Nuevo León, con Noticias sobre Coahuila, Tamaulipas, Texas y Nuevo México. Estudio Preliminar y Notas de Israel Cavazos Garza. Biblioteca de Nuevo León, Centro de Estudios Humanisticos de la Universidad de Nuevo León. Monterrey.

León, Nicolás

1901 Familias Lingüisticas de México. México.

Leutenegger, Benedict

1977 Inventory of the Mission San Antonio de Valero: 1772. Texas Historical Commission, office of the State Archeologist, Special Report 20. Austin.

Maas, P. Otto

1915 Viajes de Misioneros Franciscanos á la Conquista del Nuevo México. Sevilla.

MacManus, T. E.

1885 La Sal del Rey, or the King's Salt. . Brownsville.

Martin, George C. (editor)

1947 Expedition into Texas of Fernando del Bosque, Standard-bearer of the King, Don Carlos II, in the Year 1675. Translated by Betty B. Brewster. San Antonio.

Martinez del Río, Pablo

1954 La Comarca Lagunera a Fines del Siglo XVI y Principios del XVII según las Fuentes Escritas. Publicaciones del Instituto de Historia, Primera Serie 30. México.

Masanet (Mazanet), Damián

1957 Diario que hicieron los Padres Misioneros que Principia en 16 de Mayo y que Finaliza en 2 de Agosto de 1691. BAN 28(2):349-475. México.

Mason, J. Alden

1940 The Native Languages of Middle America. In: The Maya and Their Neighbors:52-87. New York. 
Morfi, Juan Agustín de

1856 Viage de Indios y Diario del Nuevo-México. Documentos para la Historia de México, Tercera Serie 1:305-487. México.

1935a History of Texas, 1673-1779. Translated and Annotated by Carlos Eduardo Castañeda. Quivira Society Publication 6 (two vol umes). Albuquerque.

$1935 b$ Viaje de Indios y Diario del Nuevo México. Noticia Bibliografica y Acotaciones por Vito Alessio Robles. México.

Nance, Joseph Milton

1964 Attack and Counterattack: The Texas-Mexican Frontier, 1842. University of Texas Press, Austin.

Naranjo, Leopoldo

1934 Lampazos: Sus Hombres, Su Tiempo, Sus Obras. Monterrey.

Nuñez Cabéza de Vaca, ATvar

1542 La Relacion que dio Alvar Nuñez Cabeza de Vaca. . . Zamora (photostat copy, BTHCA).

Oberste, William H.

1942 History of Refugio Mission. Refugio, Texas.

01 ivares, Antonio de San Buenaventura y

1700 Carta del Padre 01 ibares del Rio Grande (a Fray Felipe Galindo), 1700. (BTHCA, 2Q203, Vol. 466:48-51).

Orozco y Berra, Manuel

1864 Geografía de las Lenguas y Carta Etnográfica de México. México. Parisot, P. F., and C. J. Smith

1897 History of the Catholic Church in the Diocese of San Antonio, Texas. San Antonio.

Pérez de Mesquía, Pedro

1731 Carta al Señor Marqs. de Casa-Fuerte, Virrey de està Nueva España, Mayo 4 de 1731. AGN, Provincias Internas 236 (BTHCA, 2Q215, Vol. $531: 36-40$ ). 
Portillo, Esteban L.

1886 Apuntes para la Historia Antigua de Coahuila y Texas. Saltillo.

1897 Catecismo Geográfico, Político, e Histórico del Estado de Coahuila de Zaragoza. Segunda Edición. Saltillo.

Powe11, J. W.

1891 Indian Linguistic Families of America North of Mexico. Seventh Annual Report of the Bureau of Ethnology, 1885-86. Washington, D.C.

Ramón, Diego

1707 Diario de 1 a Jornada que executo Sergento Mr. Diego Ramón... AGN, Provincias Internas 28 (BTHCA, 2Q203, Vol. 466:53-71).

Reindorp, Reginald C.

1938 The Founding of Missions at La Junta de los Rios. Supplementary Studies of the Texas Catholic Historical Society 1(1). Austin.

Revilla Gigedo, Conde de

1966 Informe sobre las Misiones, 1793, e Instrucción Reservada al Marques de Branciforte, 1794. México.

Ríos, Eduardo Enrique

1959 Life of Fray Antonio Margil, O.F.M., Translated and Revised by Benedict Leutenegger. Academy of American Franciscan History, Washington, D.C.

Rivera y Villalón, Pedro de

1945 Diario y Derrotero de la Caminado, Visto Obcervado en el Discurso de Visita General de Precidios situados en las

Provincias Internas de Nueva España. México.

Rodríguez, Vicente

$1772 a$ Testimonio de la Entrega de la Mision de San Bernardo del Rio Grande del Norte, a las Reverendos Padres de la Santa Provincia de Jalisco, Año de 1772. SA (BTHCA, 2Q313, Vol. 3:34-75).

1772b Testimonia de los Bienes de la Mision de San Juan Bautista de Rio Grande. SA (BTHCA, 2Q313, Vol. 3:76-134). 
Ruecking, Frederick H., Jr.

1953 The Economic System of the Coahuiltecan Indians of Southern Texas and Northeastern Mexico. The Texas Journal of Science 5(4):480-498. San Marcos.

1954a Bands and Band-clusters of the Coahuiltecan Indians. Student Papers in Anthropology. The Department of Anthropology, The university of Texas 1(2):1-24. Austin.

1954b Ceremonies of the Coahuiltecan Indians of Southern Texas and Northeastern Mexico. The Texas Journal of Science 6(3):330339. San Marcos.

1955a The Coahuiltecan Indians of Southern Texas and Northeastern Mexico. Unpublished M. A. Thesis, The University of Texas at Austin.

1955b The Social Organization of the Coahuiltecan Indians of Southern Texas and Northeastern Mexico. The Texas Journal of Science $7(4): 357-388$. Austin.

Saldivar, Gabriel

1943 Los Indios de Tamaulipas. Instituto Panamericana de Geografia e Historia, Publicacion 70. México.

1946 Organización de las Misiones. Archivo de la Historia de Tamaulipas, la Serie 3. México.

San Buenaventura y Salazar, Diego

1699 Misiones de Coahuila. AGI, Audiencia de México (BTHCA, 2Q145, Vol. 72:44-47).

1708 Misiones de Coahuila. AGI, Audiencia de México (BTHCA, 2Q146, Vo1. 77:11-28).

Sandoval, Manuel de

1733 Copy of residencia of Governor Don Juan Anttonio de Bustillo y Zevallos conducted by Governor Don Manuel de Sandoval by order of the Marques de Casafuerte. BAT 3:1-213.

Santa Ana, Benito Fernando de

1743 Carta, Marzo 4 de 1743, de la Mision de la Conzepcion de Acuña. AGN, Provincias Internas 236 (BTHCA, 2Q215, Vol. 531:69-75). 
Santos, Richard J.

1966- A Preliminary Survey of the San Fernando Archives. Texas 1967 Libraries 28(4):152-172. Austin.

Saravia, Atanasio G.

1937 Ensayos Historicos. México.

Sarmiento, José

1701 Testimonio del Decreto de Fundacion del Precidio de San Juan Bautizta. AGN, Historia 29 (BTHCA, 2Q178, Vol. 348:69-76).

Sauer, Carl

1934 The Distribution of Aboriginal Tribes and Languages in Northwestern Mexico. Ibero-Americana 5. Berkeley.

Scholes, F. V. and H. P. Mera

1940 Some Aspects of the Jumano Problem. Carnegie Institution Contributions to American Anthropology and History 6:265299. Washington, D.C.

Schroeder, Albert $H$.

1960 A Study of the Apache Indians, Part III. The Mescalero Apaches. Multilithed. Santa Fe.

Sevillano de Paredes, Miguel

1726 Representacion que haze Fray Miguel Sevillano de Paredes . . a1 muy Reverendo Padre Fray Pedro Perez de Mezquia, Santa Cruz de Queretaro. BTHCA, 2Q237, Vol. 766:36-41 (Dunn Transcripts).

1727 Visita de las Misiones del Rio Grande del Norte por F. Miguel Sevillano de Paredes en 15 de Octubre de 1727 . AGN, Historia 29 (BTHCA, 2Q178, Vol. 348:35-68).

She iby, Charmion C.

1923 St. Denis's Declaration Concerning Texas in 1717. SHQ 26(3): 165-183.

Simmons, Marc

1964 Tlascalans in the Spanish Borderlands. NMHR 39(2):101-110. 
Sjoberg, Andrée F.

1953 The Culture of the Tonkawa, A Texas Indian Tribe. The Texas Journal of Science 5(3):280-304. Austin.

Solano Registers

ms. The baptismal, marriage, and burial registers of Mission San Francisco Solano are in the San Fernando Archives, San Antonio, Texas (see Santos, 1966-1967). Photostat and microfilm copies are in the Texas Catholic Archives, Austin, Texas.

Steck, Francis Borgia

1932 Forerunners of Captain de Leon's Expedition to Texas, 1670-1675. SHQ 36(1):1-28.

Stiles, Henry Reed, editor

1906 Ioutel's Journal of La Salle's Last Voyage, 1684-7. Albany.

Swadesh, Mauricio

1959 Mapas de Clasificación Lingüística de México y las Americas. Cuadernos del Instituto de Historia, Serie Antropología, Universidad Nacional Autónoma de México 8. México.

1967 Linguistic Classification in the Southwest. In: Dell H. Himes and William E. Bittle, editors, Studies in Southwestern Ethnolinguistics:281-309. Mouton \& Co., The Hague and Paris.

Swanton, John R.

1940 Linguistic Material from the Tribes of Southern Texas and Northeastern Mexico. SIBAE 127.

1942 Source Material on the History and Ethnology of the Caddo Indians. SIBAE 132:

1952 The Indian Tribes of North America. SIBAE 145.

Tous, Gabriel

1930a Ramón Expedition: Espinosa's Diary of 1716. PTCHS 1(4).

1930b The Espinosa-01 ivares-Aguirre Expedition of 1709: Espinosa's Diary. PTCHS 1(3).

Troike, Rudolph G.

1962 Notes on Coahuil tecan Ethnography. Bulletin of the Texas Archeological Society 32:57-63. Austin. 
Trowbridge, A. C.

1923 A Geologic Reconnaissance in the Gulf Coastal Plain of Texas, near the Rio Grande. In: David White, editor, Shorter Contributions to General Geology, 1922:85-107. United States Geological Survey, Professional Papers 131. Washington, D.C.

Valero Registers

ms. Baptismal, marriage, and burial registers for Mission San Antonio de Valero are in the San Fernando Archives, San Antonio, Texas (see Santos, 1966-1967). Photostat and microfilm copies are in the Texas Catholic Archives, Austin, Texas.

Velasco, Al fonso Luis

1897 Geografía y Estadística de la Republica Mexicana 19. México. Velasco, Dr.

1958 Dictamen Fiscal, México y Noviembre 30 de 1716. BAN 29(2): 311-344.

Vetancurt, Fr. Agustin de

1971 Teatro Mexicano . . Editorial Porrua; México.

Webb, Walter Prescott, editor-in-chief

1952 The Handbook of Texas. The Texas State Historical Association (two volumes), Austin.

Weddle, Robert S.

1968 San Juan Bautista: Gateway to Spanish Texas. University of Texas Press, Austin and London.

1973 Wilderness Manhunt: The Spanish Search for La Salle. University of Texas Press, Austin and London.

Wheat, Car1 I.

1957 Mapping the Transmississippi west, 1540-1861. The Institute of Historical Cartography (two volumes), San Francisco.

Wilcox, Seb. S.

1946 The Spanish Archives of Laredo. SHR 49(3):341-360. 
Williams, J. W.

1962 New Conclusions on the Route of Mendoza, 1683-1684. West Texas Historical Association Year Book 38:111-134. Abilene.

Winfrey, Dorman H., and James M. Day

1966 The Indian Papers of Texas and the Southwest, 1825-1916 (five volumes). Austin.

Ximénes, Diego

1762a Relación del Estado de las Misiones de la Precidencia del Rio Grande, pertenecientes al Colegio de la Santa Cruz de Queretaro. AGN, Historia 29 (BTHCA, 2Q178, Vol. 348:108-115).

1762b Ibid., BTHCA, 2Q178, Vol. 349:104-111.

Zel is (Celis), Francisco de

1734 Mision nombre de Jhs alias Peyot. AGI, Audiencia de México (BTHCA, 2Q147, Vol. 84:8-9). 